Prepared in cooperation with the

Shinnecock Nation and the Suffolk County Department of Health Services

\title{
Hydrologic Assessment of the Shallow Groundwater Flow System Beneath the Shinnecock Nation Tribal Lands, Suffolk County, New York
}

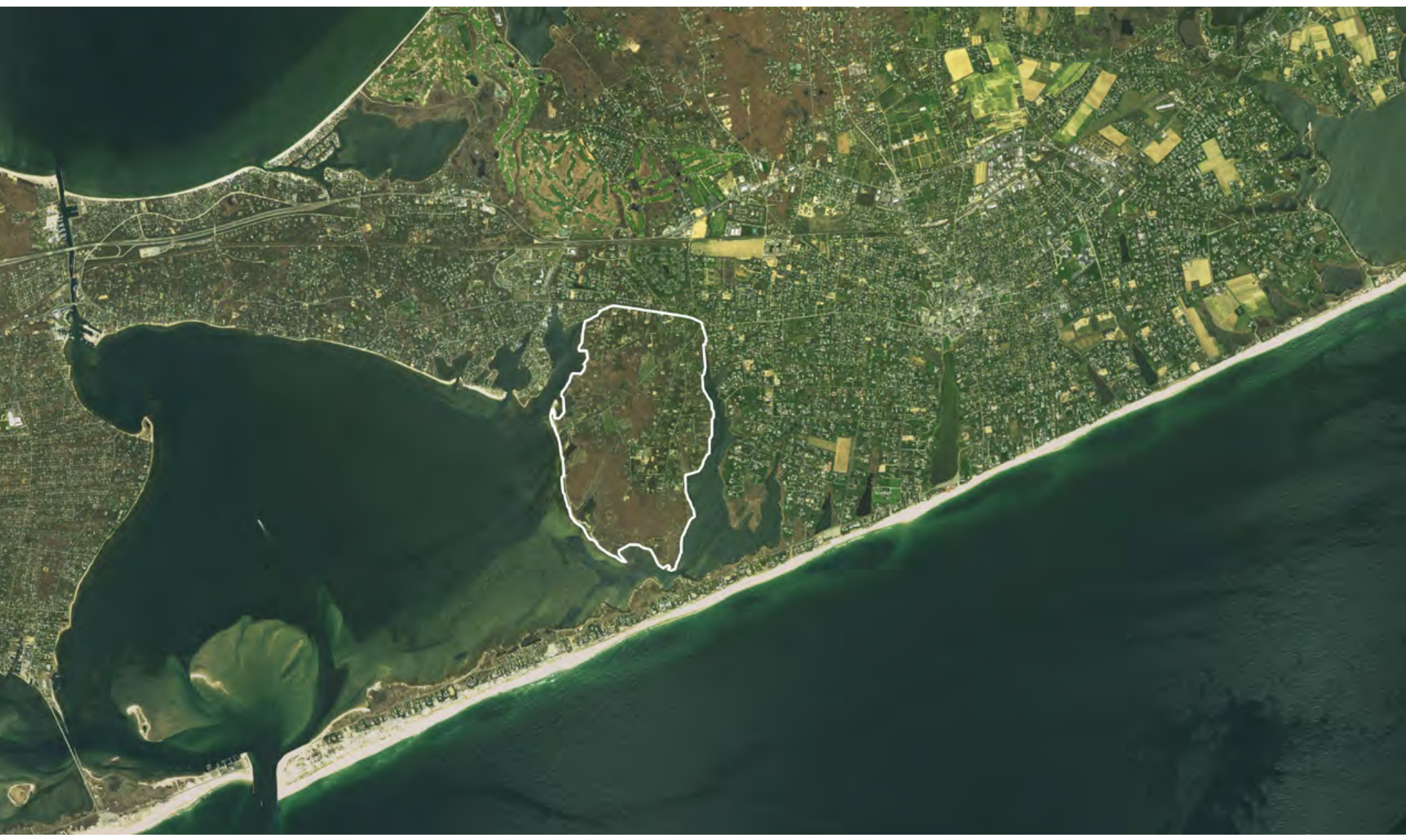

Scientific Investigations Report 2016-5110 


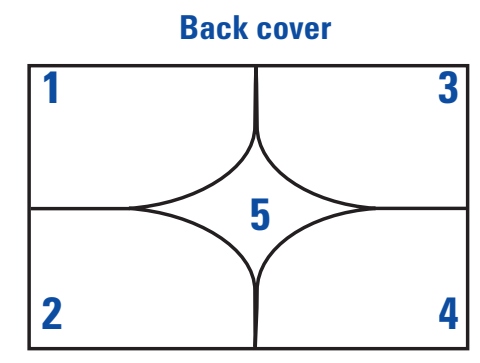

Cover. Front cover. Aerial image of the Shinnecock Nation tribal lands from Google Earth, Esri and others.

Lower banner. Panoramic photo of Shinnecock Bay taken from Cuffee Beach at the Shinnecock Nation tribal lands. Photograph by Marie Zuck.

Back cover. (1) U.S. Geological Survey scientist calibrating an electromagnetic-induction borehole probe at the Shinnecock Nation tribal lands. (2) Suffolk County Department of Health Services Geoprobe rig installing a monitoring well at the Shinnecock Nation tribal lands. (3) U.S. Geological Survey scientist measuring water-quality parameters and discharge rate during an aquifer test at the Shinnecock Nation tribal lands. (4) U.S. Geological Survey scientist downloading data from a water level recorder at the Shinnecock Nation tribal lands. (5) Global Navigation Satellite System base station located near Cuffee Beach at the Shinnecock Nation tribal lands. 


\section{Hydrologic Assessment of the Shallow Groundwater Flow System Beneath the Shinnecock Nation Tribal Lands, Suffolk County, New York}

By Michael L. Noll, Simonette L. Rivera, and Ronald Busciolano

Prepared in cooperation with the

Shinnecock Nation and the Suffolk County Department of Health Services

Scientific Investigations Report 2016-5110 


\title{
U.S. Department of the Interior SALLY JEWELL, Secretary
}

\section{U.S. Geological Survey Suzette M. Kimball, Director}

\author{
U.S. Geological Survey, Reston, Virginia: 2016
}

For more information on the USGS - the Federal source for science about the Earth, its natural and living resources, natural hazards, and the environment-visit http://www.usgs.gov or call 1-888-ASK-USGS.

For an overview of USGS information products, including maps, imagery, and publications, visit http://store.usgs.gov.

Any use of trade, firm, or product names is for descriptive purposes only and does not imply endorsement by the U.S. Government.

Although this information product, for the most part, is in the public domain, it also may contain copyrighted materials as noted in the text. Permission to reproduce copyrighted items must be secured from the copyright owner.

Suggested citation:

Noll, M.L., Rivera, S.L., and Busciolano, Ronald, 2016, Hydrologic assessment of the shallow groundwater flow system beneath the Shinnecock Nation tribal lands, Suffolk County, New York: U.S. Geological Survey Scientific Investigations Report 2016-5110, 44 p., http://dx.doi.org/10.3133/sir20165110.

ISSN 2328-031X (print)

ISSN 2328-0328 (online) 


\section{Acknowledgments}

The authors express sincere thanks and gratitude to the Shinnecock Nation for their cooperation and providing access to their land. Special thanks to Shavonne Smith and Viola Cause of the Shinnecock Nation Environmental Department for their logistical support throughout the project and for providing access to primary-source documents. The authors are grateful to the Suffolk County Department of Health Services for drilling the new water table wells presented in this report.

We also thank Anthony Chu, Frederick Stumm, Jack Monti, and Lynn Torak of the U.S. Geological Survey for their technical support. Thanks to Monique Fordham of the U.S. Geological Survey for facilitating relations between the USGS scientists on Long Island and the Shinnecock Nation.

This study was funded by appropriations from the Disaster Relief Appropriations Act of 2013 (Public Law 113-2), which provides the U.S. Department of the Interior and its bureaus funding for projects that promote improvements in community and ecological system resilience after Hurricane Sandy. 



\section{Contents}

Acknowledgments ...............................................................................................................................

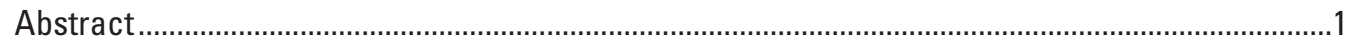

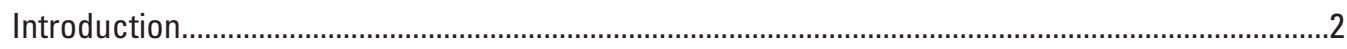

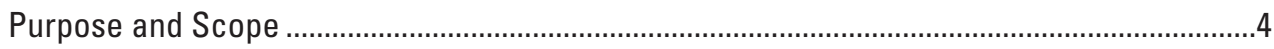

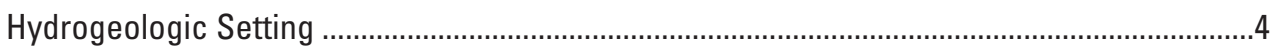

Climate and Precipitation .........................................................................................................

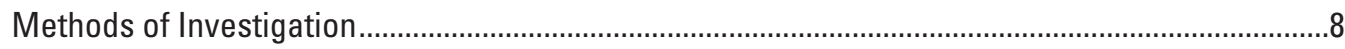

Water Table Well Network ………….....................................................................................

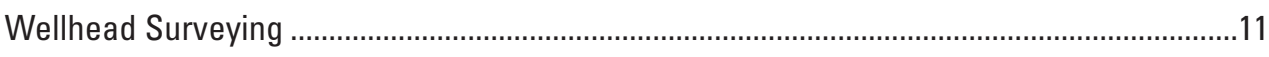

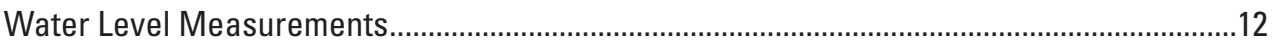

Water Table Surface and Depth-to-Water Mapping ............................................................12

Specific-Capacity Tests and Derived Estimates of Hydraulic Conductivity..............................12

Applied Borehole and Surface Geophysical Methods ...........................................................14

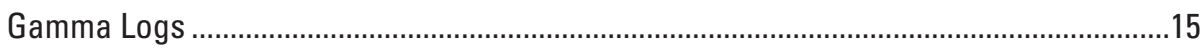

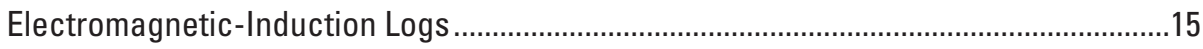

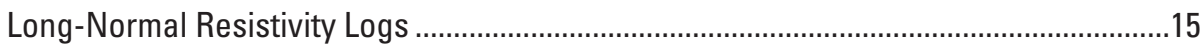

Time-Domain Electromagnetic Soundings ....................................................................15

Hydrologic Assessment of the Shallow Groundwater Flow System............................................16

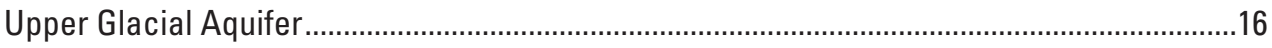

Contact With Underlying Magothy Aquifer .................................................................16

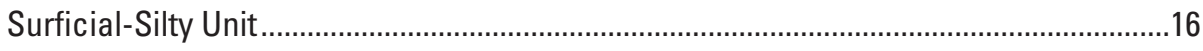

Water Table Configuration and Conceptualization of Groundwater Flow.......................19

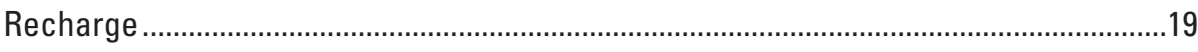

Effect of Precipitation on Groundwater Levels............................................................22

Seasonal Water Level Fluctuations and Estimated Change in Groundwater Volume ...22

Tidal Influence on Water Table .....................................................................................24

Analysis of Continuous Water Level Data from Selected Wells......................................24

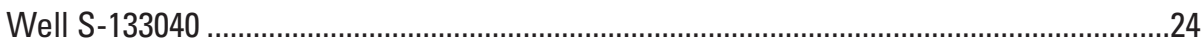

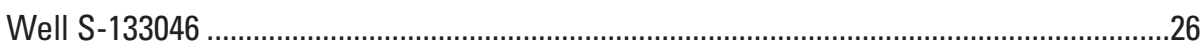

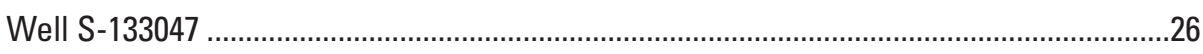

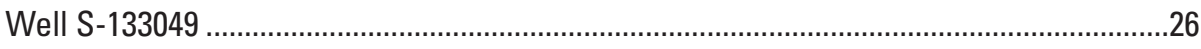

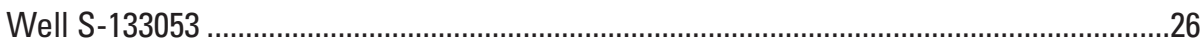

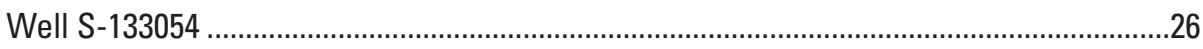

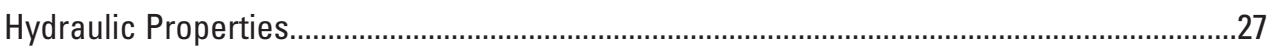

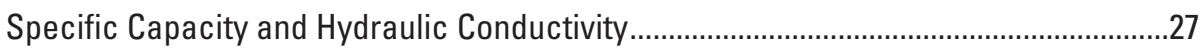

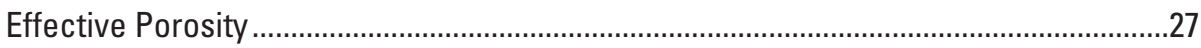

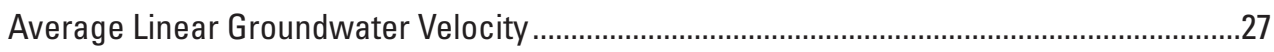

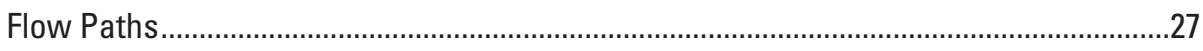

Continuous Hydraulic-Gradient Surface ..................................................................30

Continuous Hydraulic-Conductivity Surface ..................................................................30

Groundwater Travel Time ..........................................................................................

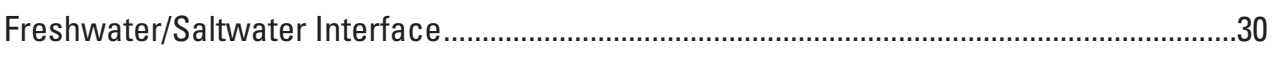

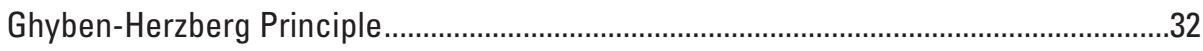


Conclusions

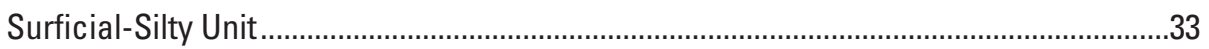

Saltwater in the Upper Glacial and Magothy Aquifers ………………..........................33

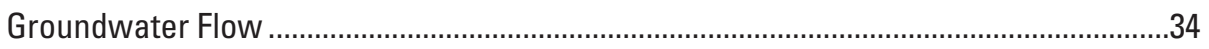

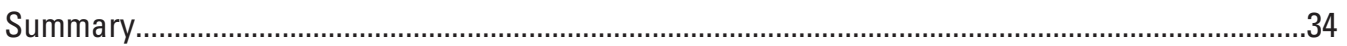

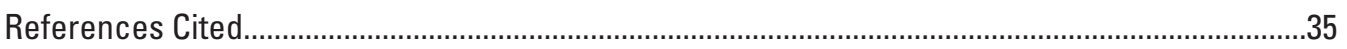

Appendix 1. Water Level Altitude and Precipitation Measured at Selected Wells at the Shinnecock Nation Tribal Lands, Shinnecock, New York................................................40

Appendix 2. Water Level Altitude and Tide Stage at the Shinnecock Nation Tribal Lands,

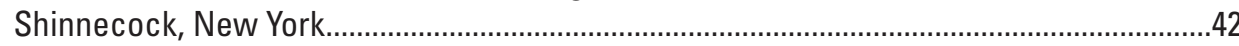

Appendix 3. Geophysical Log Collected at the Shinnecock Nation Tribal Lands, Shinnecock, New York..

\section{Figures}

1. Map showing location of the Shinnecock Nation tribal lands study area, observation wells and test borings, National Weather Service meteorological station, and National Oceanographic and Atmospheric Administration tideprediction station, Suffolk County, New York.

2. Section showing the major hydrogeologic units underlying or adjacent to the Shinnecock Nation tribal lands, Suffolk County, New York...

3. Map showing surficial geology of the Shinnecock Nation tribal lands and surrounding area, Suffolk County, New York

4. Graph showing water levels at observation well S-8836, and annual precipitation at Bridgehampton, New York, cooperative-meteorological station, 1930-2014

5. Graph showing water levels at observation well S-8836, total monthly precipitation, and average monthly precipitation at Bridgehampton, New York, cooperative-meteorological station, 2014

6. Map showing location of the Shinnecock Nation tribal lands study area, observation wells, and test borings, Suffolk County, New York.

7. Graphs showing altitude of water levels in observation wells: $A, S-133049$;

$B, \mathrm{~S}-133040 ; C, \mathrm{~S}-133053$; and $D, \mathrm{~S}-133046$ in relation to daily precipitation at

Bridgehampton, Suffolk County, New York.

8. Graphs showing altitude of water levels in observation wells: $A, S-133049$;

$B, \mathrm{~S}-133040 ; C, \mathrm{~S}-133053$; and $D, \mathrm{~S}-133046$ in relation to predicted tide stage at

Ponquogue Point, Suffolk County, New York.

9. Map showing measured depth-to-water, and estimated continuous depth-towater surface at Shinnecock Nation tribal lands, Suffolk County, New York, for water levels measured at high tide during May 2014

10. Section $A-A^{\prime}$ showing gamma logs, water table, land-surface topography, and estimated depth of hydrogeologic contacts underlying or adjacent to the Shinnecock Nation tribal lands, Suffolk County, New York

11. Maps showing water table altitude during $A$, May 2014; and B, November 2014 at the Shinnecock Nation tribal lands, Suffolk County, New York.

12. Map showing seasonal difference of water table altitude at Shinnecock Nation tribal lands, Suffolk County, New York, 2014 
13. Map showing interpreted water level difference contours, and calculated water level difference values in observation wells at the Shinnecock Nation tribal lands, Suffolk County, New York, 2014

14. Map showing measured and interpreted hydraulic conductivity, water level altitude contours, and flow-path segments near the Shinnecock Nation tribal lands, Suffolk County, New York, May 2014.

15. Section $A-A^{\prime}$ showing electromagnetic-induction logs, time-domain electromagnetic-induction soundings, electrical-resistivity logs, and estimated freshwater/saltwater interface beneath the Shinnecock Nation tribal lands,

Suffolk County, New York

\section{Tables}

1. Site information for groundwater wells on or near the Shinnecock Nation tribal lands, Suffolk County, New York

2. Estimated specific capacity and hydraulic conductivity for select wells on or near the Shinnecock Nation tribal lands, Suffolk County, New York.

3. Estimated travel time of groundwater along conceptualized flow-path segments beneath the Shinnecock Nation tribal lands, Suffolk County, New York...

4. Estimated freshwater/saltwater interface altitude at select wells on or near Shinnecock Nation tribal lands, Suffolk County, New York. 


\section{Conversion Factors}

U.S. customary units to International System of Units

\begin{tabular}{|c|c|c|}
\hline Multiply & By & To obtain \\
\hline \multicolumn{3}{|c|}{ Length } \\
\hline inch (in.) & 25.4 & millimeter $(\mathrm{mm})$ \\
\hline foot $(\mathrm{ft})$ & 0.3048 & meter $(\mathrm{m})$ \\
\hline mile (mi) & 1.609 & kilometer $(\mathrm{km})$ \\
\hline \multicolumn{3}{|c|}{ Area } \\
\hline square mile $\left(\mathrm{mi}^{2}\right)$ & 259.0 & hectare (ha) \\
\hline square mile $\left(\mathrm{mi}^{2}\right)$ & 2.590 & square kilometer $\left(\mathrm{km}^{2}\right)$ \\
\hline \multicolumn{3}{|c|}{ Volume } \\
\hline gallon (gal) & 3.785 & liter $(\mathrm{L})$ \\
\hline gallon (gal) & 0.003785 & cubic meter $\left(\mathrm{m}^{3}\right)$ \\
\hline gallon (gal) & 3.785 & cubic decimeter $\left(\mathrm{dm}^{3}\right)$ \\
\hline million gallons (Mgal) & 3,785 & cubic meter $\left(\mathrm{m}^{3}\right)$ \\
\hline \multicolumn{3}{|c|}{ Flow rate } \\
\hline foot per day (ft/d) & 0.3048 & meter per day $(\mathrm{m} / \mathrm{d})$ \\
\hline gallon per minute (gal/min) & 0.06309 & liter per second $(\mathrm{L} / \mathrm{s})$ \\
\hline inch per year (in/yr) & 25.4 & millimeter per year $(\mathrm{mm} / \mathrm{yr})$ \\
\hline \multicolumn{3}{|c|}{ Specific capacity } \\
\hline $\begin{array}{l}\text { gallon per minute per foot } \\
[(\mathrm{gal} / \mathrm{min}) / \mathrm{ft})]\end{array}$ & 0.2070 & $\begin{array}{l}\text { liter per second per meter } \\
{[(\mathrm{L} / \mathrm{s}) / \mathrm{m}]}\end{array}$ \\
\hline \multicolumn{3}{|c|}{ Hydraulic conductivity } \\
\hline foot per day $(\mathrm{ft} / \mathrm{d})$ & 0.3048 & meter per day $(\mathrm{m} / \mathrm{d})$ \\
\hline \multicolumn{3}{|c|}{ Hydraulic gradient } \\
\hline foot per mile (ft/mi) & 0.1894 & meter per kilometer $(\mathrm{m} / \mathrm{km})$ \\
\hline \multicolumn{3}{|c|}{ Transmissivity* } \\
\hline foot squared per day $\left(\mathrm{ft}^{2} / \mathrm{d}\right)$ & 0.09290 & meter squared per day $\left(\mathrm{m}^{2} / \mathrm{d}\right)$ \\
\hline
\end{tabular}

Temperature in degrees Celsius $\left({ }^{\circ} \mathrm{C}\right)$ may be converted to degrees Fahrenheit $\left({ }^{\circ} \mathrm{F}\right)$ as ${ }^{\circ} \mathrm{F}=\left(1.8 \times{ }^{\circ} \mathrm{C}\right)+32$.

Temperature in degrees Fahrenheit $\left({ }^{\circ} \mathrm{F}\right)$ may be converted to degrees Celsius $\left({ }^{\circ} \mathrm{C}\right)$ as ${ }^{\circ} \mathrm{C}=\left({ }^{\circ} \mathrm{F}-32\right) / 1.8$.

\section{Datum}

Vertical coordinate information is referenced to the North American Vertical Datum of 1988 (NAVD 88). In this report this datum is also referred to as sea level.

Horizontal coordinate information is referenced to the North American Datum of 1983 (NAD 83). Altitude, as used in this report, refers to distance above the vertical datum. 


\section{Abbreviations}

$\begin{array}{ll}\text { asl } & \text { above sea level } \\ \text { bls } & \text { below land surface } \\ \text { GIS } & \text { geographic information system } \\ \text { GPS } & \text { Global Positioning System } \\ \text { GNSS } & \text { Global Navigation Satellite System } \\ \text { lidar } & \text { light detection and ranging } \\ \text { Mya } & \text { million years ago } \\ \text { NOAA } & \text { National Oceanic and Atmospheric Administration } \\ \text { NGS } & \text { National Geodetic Survey } \\ \text { NWS } & \text { National Weather Service } \\ \text { PVC } & \text { polyvinyl chloride } \\ \text { RTK } & \text { real-time kinematics } \\ \text { SCDHS } & \text { Suffolk County Department of Health Services } \\ \text { USGS } & \text { U.S. Geological Survey }\end{array}$





\title{
Hydrologic Assessment of the Shallow Groundwater Flow System Beneath the Shinnecock Nation Tribal Lands, Suffolk County, New York
}

\author{
By Michael L. Noll, Simonette L. Rivera, and Ronald Busciolano
}

\section{Abstract}

Defining the distribution and flow of shallow groundwater beneath the Shinnecock Nation tribal lands in Suffolk County, New York, is a crucial first step in identifying sources of potential contamination to the surficial aquifer and coastal ecosystems. The surficial or water table aquifer beneath the tribal lands is the primary source of potable water supply for at least 6 percent of the households on the tribal lands. Oyster fisheries and other marine ecosystems are critical to the livelihood of many residents living on the tribal lands, but are susceptible to contamination from groundwater entering the embayment from the surficial aquifer. Contamination of the surficial aquifer from flooding during intense coastal storms, nutrient loading from fertilizers, and septic effluent have been identified as potential sources of human and ecological health concerns on tribal lands.

The U.S. Geological Survey (USGS) facilitated the installation of 17 water table wells on and adjacent to the tribal lands during March 2014. These wells were combined with other existing wells to create a 32-well water table monitoring network that was used to assess local hydrologic conditions. Survey-grade, global-navigation-satellite systems provided centimeter-level accuracy for positioning wellhead surveys. Water levels were measured by the USGS during May (spring) and November (fall) 2014 to evaluate seasonal effects on the water table. Water level measurements were made at high and low tide during May 2014 to identify potential effects on the water table caused by changes in tidal stage (tidal flux) in Shinnecock Bay. Water level contour maps indicate that the surficial aquifer is recharged by precipitation and upgradient groundwater flow that moves from the recharge zone located generally beneath Sunrise Highway, to the discharge zone beneath the tribal lands, and eventually discharges into the embayment, tidal creeks, and estuaries that bound the tribal lands to the east, south, and west.

Water levels in many of the wells in the network fluctuated in response to precipitation, upgradient groundwater flow, and tidal flux in Shinnecock Bay. Water level altitudes ranged from 6.66 to 0.47 feet $(\mathrm{ft})$ above the North American
Vertical Datum of 1988 during the spring measurement period, and from 5.25 to $-0.24 \mathrm{ft}$ (NAVD 88) during fall 2014. Historically, annual and seasonal precipitation seem to indicate long-term water level trends in an index well located in the town of Southampton, correlates with changes in storage in the upper glacial aquifer, but does not necessarily indicate water level extremes in the shallow groundwater system. To place the study period in perspective, calendar year 2014 was the $32 \mathrm{~d}$ wettest year on record, with precipitation for the year totaling 48.1 inches, a 2.6-percent increase from the annual average (46.9 inches per year), based on 81 years of complete record at the National Oceanographic and Atmospheric Administration, National Weather Service cooperative meteorological station at Bridgehampton, New York. Estimated recharge to the water table beneath the tribal lands from precipitation for 2014 is 25.4 inches.

Tidal flux caused water levels in wells to fluctuate from 0.30 to $-0.24 \mathrm{ft}$ during May 2014. Water levels in wells located north of Old Fort Pond and beneath the southernmost extent of the tribal lands were most influenced by tidal flux. During June 2014, hydrographs indicate that tidal flux influenced water levels by $0.48 \mathrm{ft}$ in a well located near the southernmost extent of the tribal lands approximately 0.3 miles north of Shinnecock Bay, and was zero at a well located approximately 0.5 miles south of Montauk Highway, and 0.4 miles west of Heady Creek, near the geographic center of the tribal lands. Tidal-influence delay time (time interval between peak hightide stage and corresponding peak high-water level) ranged from 1.75 hours at the well located near the southernmost extent of the tribal lands, to more than 4 hours at a well located north of Old Fort Pond, near the northwestern part of the tribal lands.

Estimated hydraulic-conductivity values derived from the results of specific-capacity tests that were completed at nine observation wells during March 2015 were used to calculate average linear velocity. Average linear velocity along conceptualized flow-path segments of the upper glacial aquifer located beneath the tribal lands was estimated using an assumed effective porosity value, and hydraulic-conductivity and hydraulic-head values that were interpolated from measured values. Groundwater travel times were estimated 
by dividing the length of the flow-path segment by the average linear velocity along the flow-path segment. Total estimated groundwater travel time along a conceptualized flow path, beginning near Sunrise Highway and terminating at Shinnecock Bay, is approximately 45 years using a porosity value of 30 percent.

A surficial-silty unit was identified from approximately 0 to $10 \mathrm{ft}$ below land surface at multiple locations beneath the tribal lands. The lithology of the surficial unit was verified by interpreted gamma log results obtained from select wells, and auger-rig drill cuttings from an observation well located near the geographic center of the tribal lands. The altitude of the unit varies with topography and was delineated along a cross section line that trends north-south along the approximate centerline (spine) of the tribal lands. The altitude of the hydrogeologic contact between the upper glacial and the Magothy aquifers generally decreases from northwest to southeast, occurs at a depth ranging from about 150 to $200 \mathrm{ft}$ beneath the tribal lands, and was identified at two locations north of the tribal lands, near Sunrise Highway and Sebonac Road. Results of electrical geophysical surveys indicate that the depth to the freshwater/saltwater interface decreases from north to south with decreasing water level altitude, and the Magothy and upper glacial aquifers contain saltwater at varying depths along the north-south trending section. Results of the surveys also indicate that the Magothy aquifer beneath the tribal lands contains brackish and salty water and is not considered a source of potable water supply. In general, depth to the interface increases with increasing geographic distance from the coastline. Low water table altitudes can result in increased saltwater encroachment into the surficial aquifer beneath the tribal lands. This upward movement and shallow depth of the freshwater/saltwater interface can jeopardize water quality in wells that supply water for domestic use.

\section{Introduction}

The Shinnecock Nation is a federally recognized Algonquin tribe on the south fork of eastern Long Island adjacent to the town of Southampton, in Suffolk County, New York (Shinnecock Nation, 2014) (fig. 1). The Shinnecock Nation lands encompass a reservation of approximately 1.2 square miles ( 760 acres), nominally 1.6 miles (mi) long, and $1 \mathrm{mi}$ wide (variable). The tribal lands are south of Montauk Highway and between three interconnected marine water bodies - Heady Creek to the east, Shinnecock Bay to the south, and Old Fort Pond to the west. The approximate northernmost boundary of the tribal lands extends northeast from Old Fort Pond, along Montauk Highway and terminates at Heady Creek to the east. Residential and commercial properties of the town of Southampton are along Montauk Highway and north of the tribal lands. The Shinnecock Inlet is approximately $3 \mathrm{mi}$ west of the southernmost extent of the tribal lands and hydraulically connects Shinnecock Bay to the
Atlantic Ocean. The inlet was formed during The Great New England Hurricane of 1938 and is the easternmost inlet of five inlets that cut the discontinuous outer barrier island south of Long Island. The easternmost segment of the outer barrier island extends east from the Shinnecock Inlet to the village of Southampton, and is approximately 300 feet (ft) south of the southernmost extent of the tribal lands across Shinnecock Bay (fig. 1).

The Shinnecock Nation became the 565th federally recognized Indian tribe by the United States Government in October 2010 (Shinnecock Nation, 2014). The Shinnecock Nation has a population of 662 residents who live in 256 housing units (U.S. Census, 2016). The Council of Trustees is an elected governing body comprising seven individuals that serve 2 -year terms as the tribe's primary administrators. The Council of Trustees is advised by the Council of Elders, and assisted by 10 advisory committees that provide information to inform decision making (Shinnecock Nation, 2014). The advisory committees assist the council on a variety of issues including education, housing, governance, land management, natural resources, veteran's affairs, finance, education, public safety, and health care. In addition to assisting the Council of Trustees, the tribe's natural resource committee works with consultants from the private and public sector to better understand ongoing environmental and human health concerns on the tribal lands.

Oyster fisheries and other marine ecosystems are critical to the livelihood of many residents living on the tribal lands, but are susceptible to contaminants entering the embayment from the shallow groundwater flow system. The quantity and quality of groundwater being discharged to marine water bodies may adversely affect the health and long-term sustainability of marine flora and fauna (Schubert and others, 2010). Harmful algal blooms resulting from nutrient enrichment are a substantial threat to the fisheries on Long Island and may be responsible for the decline of oyster yield from the Shinnecock Bay (Gobler and others, 2012). Rising sea level and saltwater intrusion, infiltration of storm overwash (surge) from intense coastal storms, nutrient loading from fertilizers, and septic effluent from wastewater disposal systems have been identified as potential sources of contamination to the surficial aquifer beneath the tribal lands. Approximately 6 percent of the households on the tribal lands use domestic wells that tap the surficial aquifer as their primary source of potable water supply (Shavonne Smith, Shinnecock Nation, written commun., 2014). Defining the configuration of the water table and the flow of shallow groundwater from recharge zones to the surrounding embayment is crucial to identifying sources of potential contamination. The Shinnecock Nation has asked the U.S. Geological Survey (USGS) to define baseline hydrologic conditions of the water table beneath the tribal lands to support decision making by tribal government and inform water resource, ecological, and infrastructure planning decisions. 


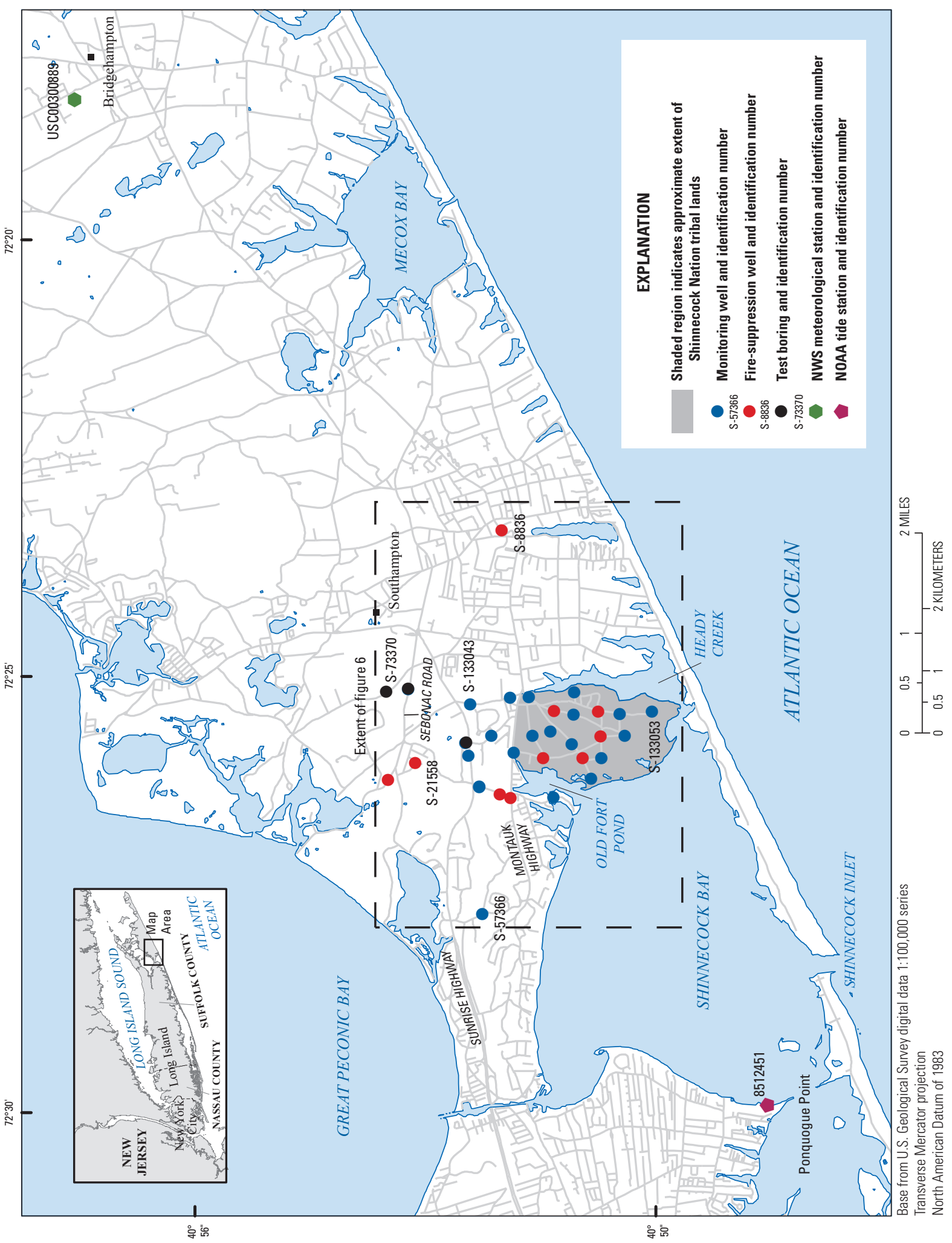

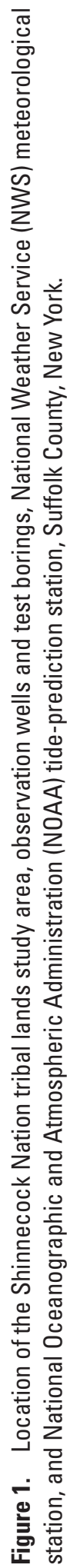


Hydrologic Assessment of Groundwater Flow Beneath Shinnecock Nation Tribal Lands, Suffolk County, New York

\section{Purpose and Scope}

This report presents a summary of the hydrologic conditions of the shallow groundwater flow system beneath the Shinnecock Nation tribal lands. Hydrologic data collected by the USGS to investigate the distribution and flow of the shallow groundwater can be used to estimate the direction and velocity of potential contaminants that may move through the surficial aquifer and discharge into Shinnecock Bay. Sections created from geophysical data and hydrogeologic data, and selected hydrographs of seasonal water level altitude are shown in illustrations. This study was completed with cooperation from the Shinnecock Nation who provided access to their land and primary-source documents; and the Suffolk County Department of Health Services who drilled the new water table wells presented in this report.

\section{Hydrogeologic Setting}

The Shinnecock Nation tribal lands are underlain by a sequence of Quaternary- and Cretaceous-age sediments that unconformably overlie Precambrian crystalline bedrock (fig. 2). The Quaternary-age sediments where permeable and saturated below the water table form the upper glacial aquifer (McClymonds and Franke, 1972). The Cretaceous-age sediments form, in descending order, the Magothy aquifer, Raritan confining unit, and Lloyd aquifer. The Quaternaryage sediments include Pleistocene moraine and outwash deposits and Holocene beach, marsh, and stream (fluvial) deposits (fig. 3). The Pleistocene moraine deposits, known as Ronkonkoma Drift, are present north and northwest of the tribal lands (Swarzenski, 1963). Glaciotectonic processes caused folding and faulting of bedding in the moraine deposits (Nemickas and Koszalka, 1982), which are characterized by foreset beds composed of sand and gravel with lenses of till and silt and clay. Permeability of these sediments is highly variable because of their heterogeneous nature. The Pleistocene outwash south of the moraine is well sorted and highly permeable deposits of sand and gravel. These stratified deposits were carried as suspended sediment or bed load, or both, in melt water from the moraine and were laid down on a shallow dipping outwash plain in a moderate-to-lowenergy environment. In general, sediment sorting increases with distance from the moraine. Holocene beach and marsh sediments have been deposited near coastlines and tidal creeks. Permeability of these deposits is variable.

The upper glacial aquifer unconformably overlies the Magothy aquifer at an altitude of about $200 \mathrm{ft}$ below sea level near the tribal lands. The Magothy aquifer consists of fineto-medium-grained sand and clay with interbedded lenses of coarse sand and solid clay. The sediments were deposited in a transitional fluviodeltaic environment (Lonnie, 1982) and coarsen downward to gravels, which commonly are present at the base of this hydrogeologic unit. Clay minerals, muscovite, lignite, pyrite, and iron-oxide concretions are common in the Magothy aquifer (Perlmutter and Geraghty, 1963; McClymonds and Franke, 1972). The Magothy aquifer locally is about $700 \mathrm{ft}$ thick (fig. 2; Smolensky and others, 1989). The Magothy aquifer is intruded by saltwater at lower altitudes (approximately $300 \mathrm{ft}$ below sea level near Sunrise Highway), and is not considered a source of potable water supply on the southern fork of Long Island near the tribal lands.

The Magothy aquifer unconformably overlies the Raritan confining unit at an altitude of about $900 \mathrm{ft}$ below sea level near the tribal lands (Perlmutter and Geraghty, 1963). The Raritan confining unit is a low-permeability formation primarily composed of clay and silty clay with a few lenses of sand that hydraulically isolates the Magothy aquifer above from the Lloyd aquifer below. The Raritan confining unit locally is about $300 \mathrm{ft}$ thick (fig. 2; Smolensky and others, 1989).

The Raritan confining unit overlies the Lloyd aquifer at an altitude of about $900 \mathrm{ft}$ below sea level near the tribal lands (fig. 2; Smolensky and others, 1989). The Lloyd aquifer consists of fine-to-coarse grained sand and gravel with interstitial clay and clay lenses. The Lloyd aquifer is confined by the Raritan clay and is poorly to moderately permeable (McClymonds and Franke, 1972). The Lloyd aquifer locally is about $250 \mathrm{ft}$ thick.

The Lloyd aquifer unconformably overlies Precambrian crystalline bedrock at an altitude of about $1,400 \mathrm{ft}$ below sea level near the tribal lands (fig. 2; McClymonds and Franke, 1972). The Precambrian bedrock is composed of igneous and metamorphic rock that is poorly permeable. The bedrock surface generally dips to the southeast at about 65 feet per mile (McClymonds and Franke, 1972). Little information is available for the Raritan confining unit, Lloyd aquifer, and bedrock beneath the tribal lands because no test borings or wells have penetrated them in this area.

\section{Climate and Precipitation}

The climate of the Shinnecock Nation tribal lands is affected by the Atlantic Ocean, Great Peconic Bay, and the Long Island Sound (fig. 1). The large marine water bodies buffer the air temperature that contributes to relatively mild winters and cooler summers. The tribal lands (and the southern fork of Long Island in general) receives less precipitation in the form of snow during winter months as compared with areas further inland because of the warming effect the marine water bodies have on air temperature. During summer, prevailing winds out of the south and southwest move cooler air from the Atlantic Ocean to the peninsula (Nemickas and Koszalka, 1982). A National Weather Service (NWS) meteorological station (USC00300889) in Bridgehampton, N.Y., has operated continuously from summer 1930 to 2016 (fig. 1). The station is approximately $8 \mathrm{mi}$ east of the tribal lands in the town of Bridgehampton at an altitude of approximately $60 \mathrm{ft}$ above sea level. Air temperature data recorded at the Bridgehampton meteorological station indicates that the 2014 annual mean temperature was 


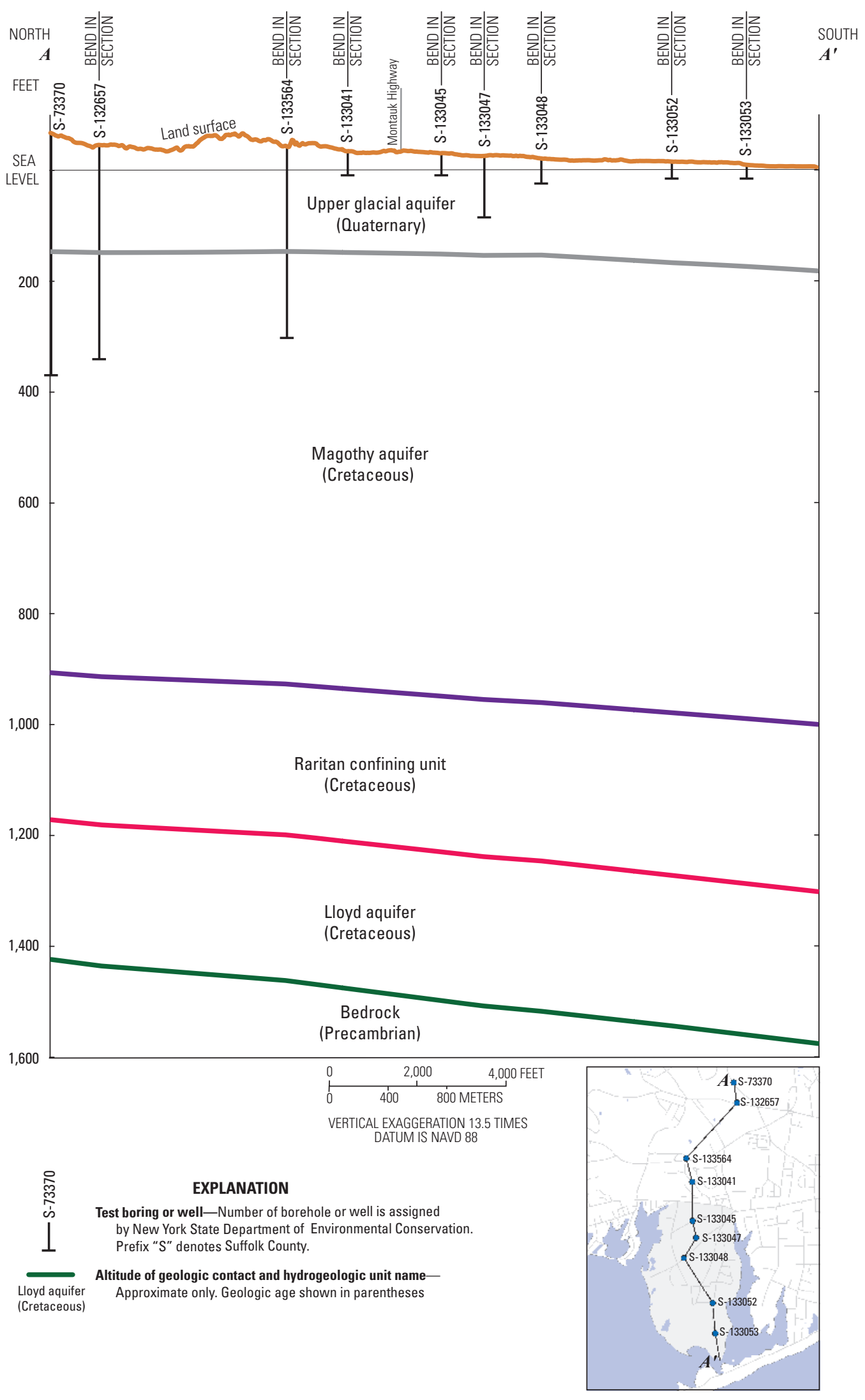

Figure 2. Section showing the major hydrogeologic units underlying or adjacent to the Shinnecock Nation tribal lands, Suffolk County, New York. Vertical exaggeration is approximately 13.5 times. Modified from Smolensky and others (1989). 


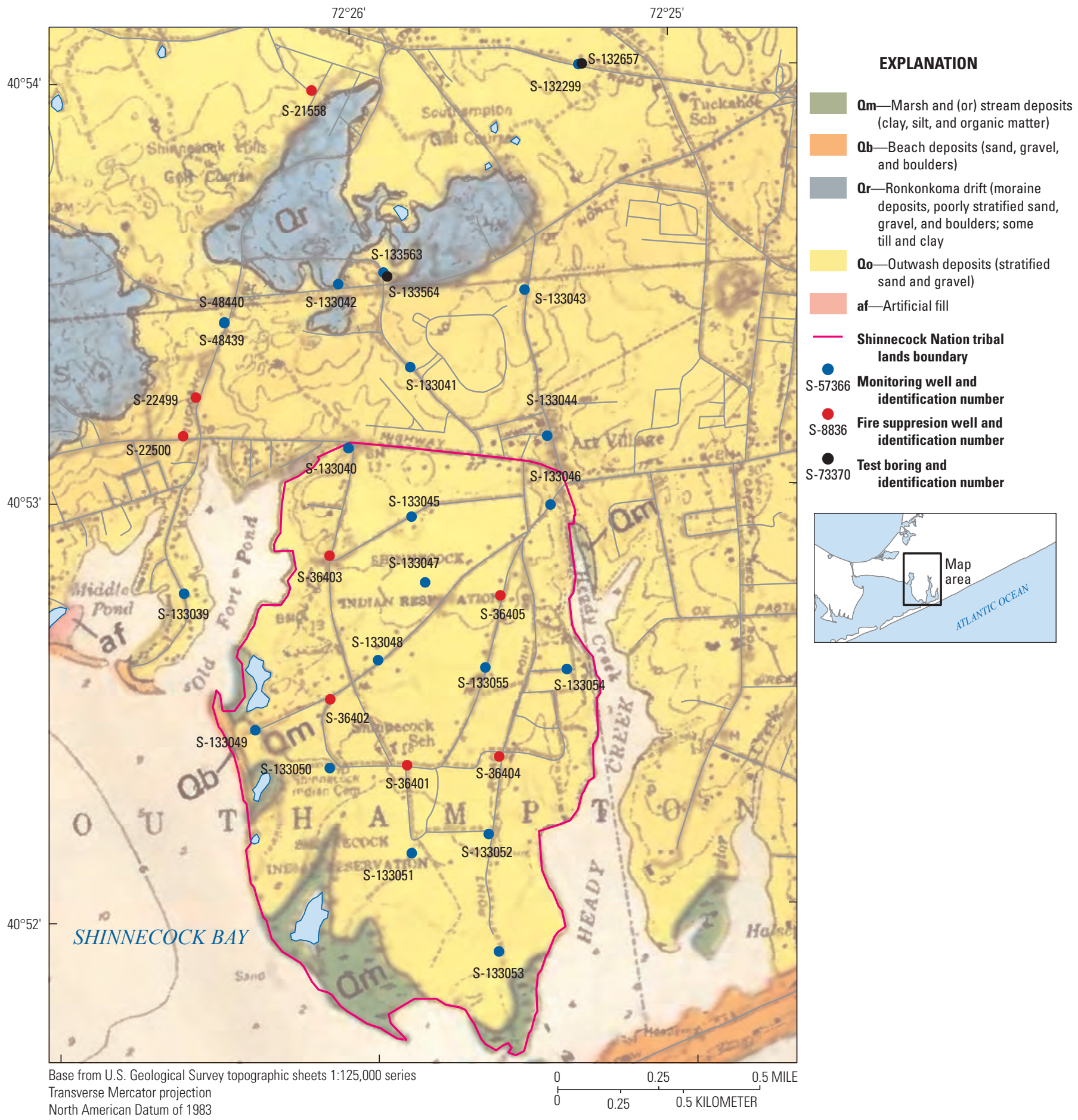

Figure 3. Surficial geology of the Shinnecock Nation tribal lands and surrounding area, Suffolk County, New York. Modified from Fuller (1914) and Nemickas and Koszalka (1982). 
50 degrees Fahrenheit $\left({ }^{\circ} \mathrm{F}\right)$. The highest daily air temperature recorded for 2014 was $86^{\circ} \mathrm{F}$ during September, and the lowest was $5^{\circ} \mathrm{F}$ during January.

Precipitation data from the Bridgehampton meteorological station was used to identify potential precipitation influence on the shallow groundwater flow system beneath the tribal lands (figs. 1, 4, and 5). Daily and monthly precipitation data were retrieved from Northeast Regional Climate Center records and tabulated in spreadsheets for analysis (National Oceanic and Atmospheric Administration, 2015). The records indicate that a 7-month period of total monthly precipitation data is missing for 1930, an 8-month period is missing for 2011, a 5-month period is missing for 2012, and a 1-month period for 2013 - average annual precipitation was not calculated for these years. Monthly precipitation totals were not calculated for months missing more than 3 days of daily data. In some cases, data were estimated from nearby meteorological stations to fill in missing total monthly precipitation values (figs. 4 and 5).
Average annual precipitation for the 81-year period of complete record at Bridgehampton is $46.9 \mathrm{in} / \mathrm{yr}$. During calendar year 1996, the Bridgehampton station recorded 67.5 in. of precipitation making it the wettest year on record. In 1965, the station recorded 30.7 in. of precipitation making it the driest year on record. Calendar year 2014 was the $32 \mathrm{~d}$ wettest year on record with total annual precipitation of 48.1 in. or 2.6 percent greater than the annual average (figs. 4 and 5).

The National Weather Service defines the winter season as December through February, the spring season as March through May, the summer season as June through August, and the fall season as September through November. The average total seasonal precipitation for winter, spring, summer, and fall recorded at the Bridgehampton station is $12.2,12.2,10.4$ and $12.0 \mathrm{in}$., respectively. The total seasonal precipitation for winter 2013-14, and spring, summer, and fall 2014 is 14.8, 13.5, 6.8, and 11.9 in., respectively. Precipitation in winter 2013-14 and spring 2014 is 21 and 11 percent greater than seasonal

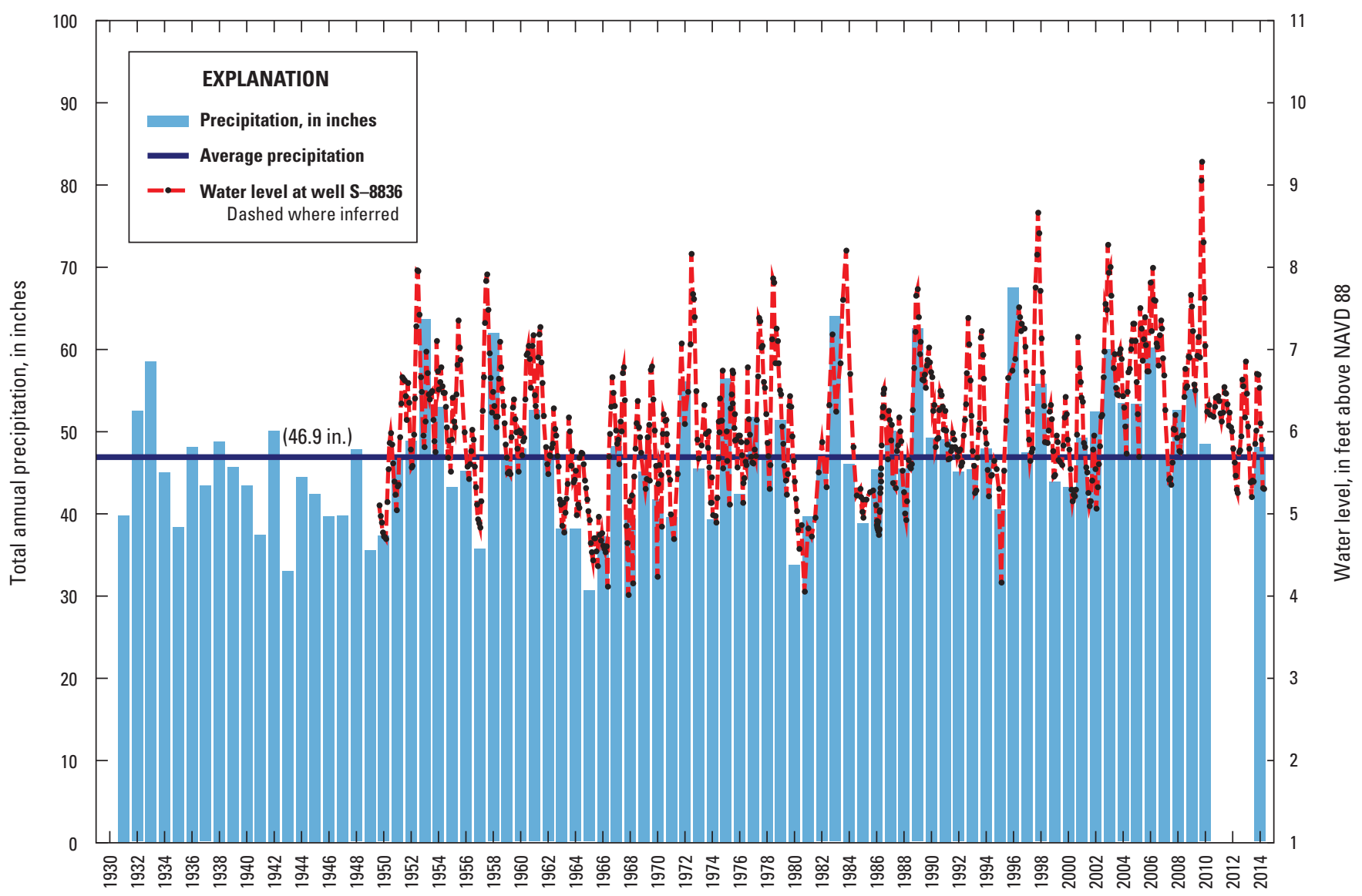

Year

Figure 4. Water levels at observation well S-8836, and annual precipitation at Bridgehampton, New York, cooperative-meteorological station, 1930-2014. Precipitation data are from National Oceanic and Atmospheric Administration (2015). NAVD 88, North American Vertical Datum of 1988. 


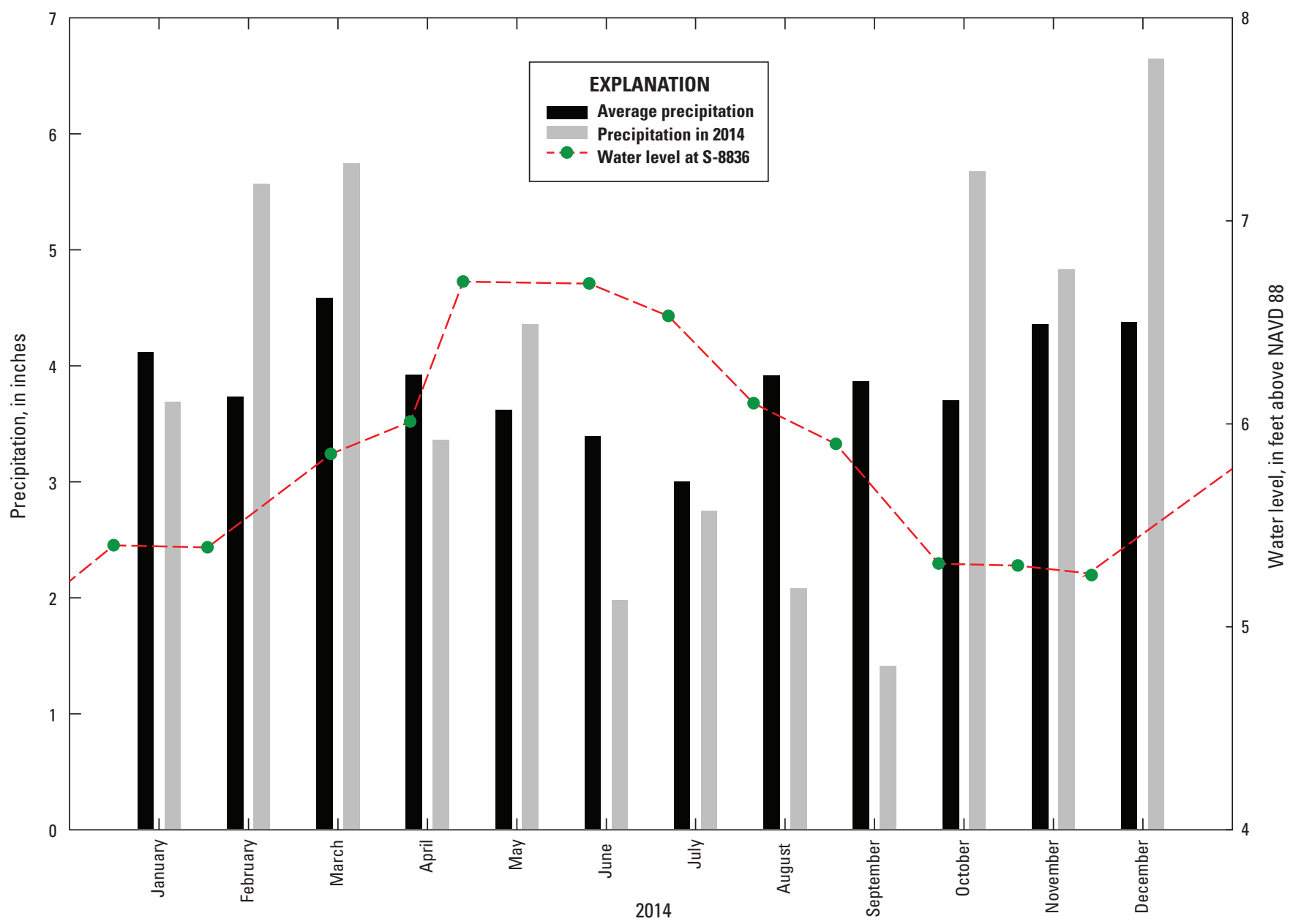

Figure 5. Water levels at observation well S-8836, total monthly precipitation, and average monthly precipitation at Bridgehampton, New York, cooperative-meteorological station, 2014. Precipitation data are from National Oceanic and Atmospheric Administration (2015). Inferred water levels are based on measured values that may not be shown in this figure. NAVD 88, North American Vertical Datum of 1988.

averages, and in summer and fall 2014 is 35 and 1 percent below the seasonal averages, respectively. Winter, spring, summer, and fall 2014 were the 13th, 31st, 69th, and 34th wettest seasons, respectively, on record at the Bridgehampton station (figs. 4 and 5).

The growing season on the southern fork of Long Island is from April to September when evapotranspiration is at its highest for the year. Periods of water surplus are more frequent in the nongrowing season when compared with the growing season because of reduced evapotranspiration (Fetter, 1976). Total precipitation for the 2014 growing season is $15.9 \mathrm{in}$., which is 27 percent lower than the average total growingseason precipitation (21.8 in.) during the 82 -year record at the Bridgehampton meteorological station. The total growingseason precipitation for 2014 ranked as the 11th driest growing season on record. Total precipitation for the 2014 nongrowing season is $23.2 \mathrm{in}$., which is 7 percent below the nongrowing season average total precipitation of $25.0 \mathrm{in}$. It is ranked as the 49th wettest nongrowing season during the 81-year record.

\section{Methods of Investigation}

The Suffolk County Department of Health Services (SCDHS), in cooperation with the USGS, drilled and constructed 17 observation wells in the upper glacial aquifer near the water table on and near the tribal lands beginning in March 2014. These observation wells were combined with existing fire-suppression wells and USGS or SCDHS observation wells completed in the water table aquifer to constitute a 32-well network used in this study (fig. 6; table 1). Groundwater measurements from the network were taken during low and high tides in May and November 2014 to determine the configuration of the water table. Continuous water level recorders were deployed in select wells to identify the influence of tidal fluctuations and precipitation on the water table aquifer, and to provide water level data for estimating hydraulic conductivity from specific-capacity tests and compute travel times. Interpreted contours were created 


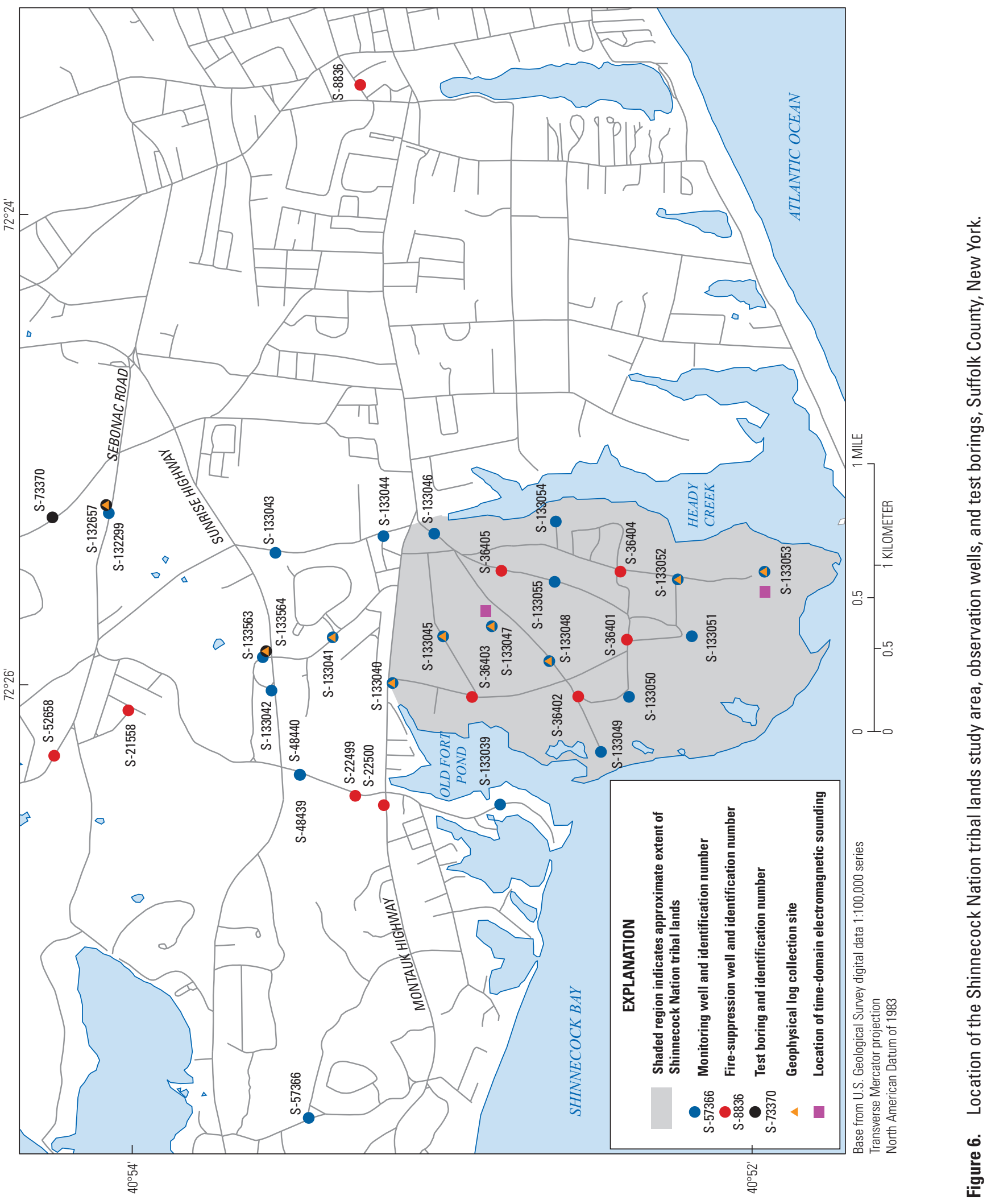




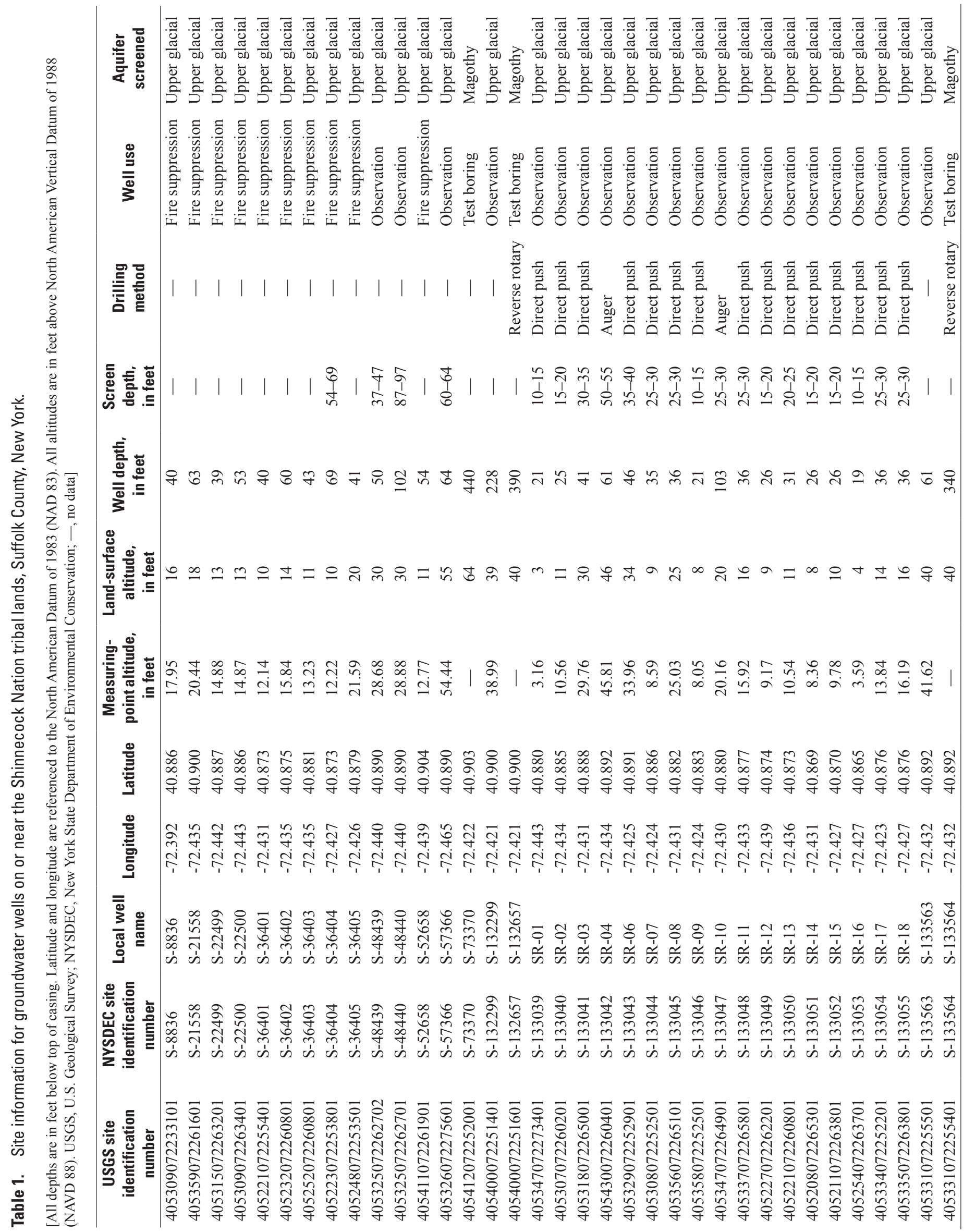


from synoptic water level measurements from May and November 2014 to determine the seasonal configuration of the water table, and to estimate the thickness of the unsaturated zone (depth-to-water) beneath tribal lands. Geophysical surveys and published hydrogeologic maps of Long Island were used to delineate the hydrogeologic units and freshwater/ saltwater interface beneath the tribal lands. Specific-capacity tests were completed at select wells in the water table network to estimate hydraulic conductivity of the shallow aquifer sediments. The hydraulic-conductivity values were used in the calculation of average linear velocity along conceptualized flow paths that were constructed from Sunrise Highway to Shinnecock Bay (fig. 6).

\section{Water Table Well Network}

Seventeen water table observation wells cased with 2-inch (in.) polyvinyl chloride (PVC) were installed on and near the tribal lands in 2014 (fig. 6; table 1) using direct-push and hollow-stem-auger drilling methods. Criteria for selecting the observation well locations included (1) a representative distribution of the water table underlying the tribal lands, (2) outpost locations that could provide hydrologic boundary conditions and constrain contour lines, and (3) sparsely populated areas, absent of utility infrastructure, that are accessible to the drill rig. Screen-zone locations were determined by offsetting (installing) the top of the screen zone approximately $5 \mathrm{ft}$ below the estimated depth-to-water using USGS depth-to-water maps (Monti and others, 2013).

A direct-push drilling method was used to drill 15 water table wells (fig. 6; table 1). The direct-push drilling method used percussion and the static vehicle weight as the source of energy to advance the tool through the subsurface. The penetrated unconsolidated material was displaced in the subsurface as the tool advanced; therefore, no soil samples were available for analysis (Geoprobe Systems, 2014). Two-in. diameter PVC casing was inserted through the drill stem and the drill stem was removed to set the well at the desired depth. The total sounded depth of the 15 observation wells that were drilled using the direct-push method ranged from 19 to $46 \mathrm{ft}$ below the top of casing (wellhead).

A hollow-stem auger drilling method was used to drill two of the water table wells (wells S-133042 and S-133047; fig. 6; table 1). Rotational speed and downward pressure on the augur flights were used to advance the auger head through the subsurface. Successive auger flights were added until the desired depth was reached. The hollow-stem drilling method allowed the well to be drilled and constructed simultaneously, which prevented caving of the borehole wall (Shuter and Teasdale, 1989). The construction of well S-133047 was atypical because approximately $75 \mathrm{ft}$ of additional well casing (sump) was added below the screen zone so that borehole geophysical logs could help identify the lithology penetrated by the well drilling. The sounded depths of wells S-133042 and S-133047 were 61 and $103 \mathrm{ft}$ below top of casing, respectively. Spin-up samples (auger cuttings) were collected during augering operations but were not considered representative of the penetrated formation except at very shallow depths.

Ten observation wells were existing fire-suppression wells constructed in the 1970s and used instead of traditional fire hydrants as sources of water to suppress fire where no public water-supply network was available (fig. 6; table 1). Water level depths in fire-suppression wells must be maintained within the suction limit of centrifugal pumps; therefore, the existence of a fire-suppression well at a given location usually indicates a depth to the water that is equal to or less than $25 \mathrm{ft}$ (Nemickas and Koszalka, 1982). Fire-suppression wells are constructed of 6-in. steel casing; however, screen-zone altitude information is unavailable (or poorly documented) but must be located above, or at the altitude of the bottom of the well. Water levels in fire suppression wells can be considered representative of the water table altitude because the sounded well depths in these 10 wells range from 39 to $69 \mathrm{ft}$ below the top of casing.

Five observation wells were existing USGS or SCDHS observation wells (fig. 6; table 1). Well diameter and construction material of these wells are variable. Sounded well depths range from 50 to $228 \mathrm{ft}$ below top of casing.

\section{Wellhead Surveying}

Single-base real-time kinematics (RTK; commonly known as rover-base Global Position System [GPS]) were used to provide centimeter-level accuracy to position objective points (well locations and vertical control) in an altitude-sensitive-controlled network. The single-base RTK surveying method requires a base station composed of a dual-frequency receiver mounted over a benchmark having a known, precisely determined location and altitude. The base station receives a satellite signal that it rebroadcasts to the objective points (mobile or rover receivers at well locations) for comparison of the signal received at the base station to the satellite signal received by the rover units. The rover receiver then calculates a correction (difference) between the known (benchmark) location and the rover locations by taking fixes on the signal transmitted from the base station, as the coordinates of the base station are known. This comparison of signals received by the rover receiver generates a correction signal from the base station to the rover receiver, resulting in positional corrections to the rover receiver in real time. These corrections are used to derive an altitude at the objective points (Rydlund and Densmore, 2012). The single-base RTK method assumes similar satellite geometry and atmospheric conditions (and other sources of positional error) at the locations of the rover and base because of the relatively small baseline distance between stations. The baseline distance between the rover stations on the tribal lands, and the base station in Bridgehampton, N.Y., is approximately $5 \mathrm{mi}$ (fig. 1). Observed positional data were localized to increase 
the positional accuracy of the objective (rover) points using observations from two National Geodetic Survey (NGS) Level 2 benchmarks located within $1.5 \mathrm{mi}$ of the tribal lands. The vertical control network was established over the course of 2 days during August 2014.

Wellhead (top of casing) altitudes were determined by conventional (differential) leveling methods by measuring the vertical difference between a point of unknown altitude (wellhead) and a point of known altitude (established vertical control) (McCormac, 1983). Standard USGS differential leveling methods (Kenney, 2010) were followed during all leveling operations.

\section{Water Level Measurements}

Water level measurements were either taken manually with a chalked, graduated steel tape or a calibrated electric tape, from the wellhead (measuring point), or calculated from pressure-transducer output that was recorded automatically by data loggers installed on select observation wells. Manual depth-to-water measurements were made in accordance with standard USGS procedures (Cunningham and Schalk, 2011). Depth-to-water measurements were converted to water altitude (levels) values by subtracting the depth-to-water measurement from the wellhead altitude. Depth-to-water measurements using the steel tape or calibrated electric tape method are considered accurate to about $0.01 \mathrm{ft}$ (Cunningham and Schalk, 2011).

Vented submersible pressure transducers were installed in wells S-133040, S-133046, S-133047, S-133049, S-133053, and S-133054 and were programmed to measure and record the height of the water column above the sensor and water temperature every 15 minutes. Data logged on these instruments were downloaded and corrected for instrument drift based on manual depth-to-water measurements that were made from the wellhead measuring points during periodic field inspections from May to November 2014. These corrected data were then converted to water altitude values. Hydrographs were created from these data for analyses (figs. 7 and 8; appendixes 1 and 2). The accuracy of a pressure transducer rated to 15 pounds per square inch $\left(\mathrm{lb} / \mathrm{in}^{2}\right)$ is approximately $0.05 \mathrm{ft}$ (In-Situ Inc., 2015).

\section{Water Table Surface and Depth-to-Water Mapping}

Water table surfaces on the tribal lands were created from measured water levels in water table observation wells at high tide during May and November 2014 by using geographic information system (GIS) modeling processes (Monti and others, 2013) that used Natural Neighbor interpolation (Sibson, 1981). This interpolation technique was used because it does not infer anomalies or trends in the data used to determine water table values at locations (points) where data do not exist, termed interpolation points or unknown-valued points. Interpolated values are a linear combination of products involving the known (measured) data values and corresponding weights; they are constrained by, and are required to be within the range of the known values. Natural Neighbor interpolation first creates Theissen polygons around the known data points (water table measurements at wells) that are closest to the interpolation point. Another polygon (Voronoi polygon) is then constructed around the interpolation point. The percentages of overlap between the Theissen polygons surrounding the known points and the Voronoi polygon surrounding the interpolation point are used to develop interpolation weights that associate the local values within each Theissen polygon to the unknown-valued point, thereby determining the value at the interpolation point (Sibson, 1981).

A GIS tool that applied mathematical functions (Nearest Neighbor interpolation) to a continuous (raster) surface, as described above, was used to create a depth-to-water surface map. The interpolated (Natural Neighbor) surface was subtracted from a high-accuracy, three-dimensional land-surface altitude model (topography) of Suffolk County, which resulted in a continuous surface (raster) that defines the thickness of the unsaturated zone (depth-to-water) on the tribal lands. The land-surface altitude model was created using light detection and ranging (lidar) measurements based on the geospatial product for coastal flood mapping (U.S. Geological Survey, 2012) (Monti and others, 2013).

\section{Specific-Capacity Tests and Derived Estimates of Hydraulic Conductivity}

Specific-capacity tests were completed at nine observation wells during March 2015 to collect the specific capacity of the well per foot of well screen, and to derive estimates for the hydraulic conductivity of the sediments opposite the screen of the water table wells (table 2). Specific capacity of a well per foot of well screen, is defined as the pumping rate divided by the water level drawdown in the pumped well sometime after the pump was started, and multiplied by the reciprocal of the screen length of the well (McClymonds and Franke, 1972) and can be expressed as follows:

$$
S C=\frac{Q}{S \times L},
$$

where

and

$S C \quad$ is specific capacity of the well, in gallons per minute per foot of drawdown and per foot of well screen;

$Q \quad$ is the pumping rate, in gallons per minute;

$L \quad$ is the screen length in feet; and

$s \quad$ is drawdown in the pumped well, in feet;

$$
s=h-h_{0}
$$



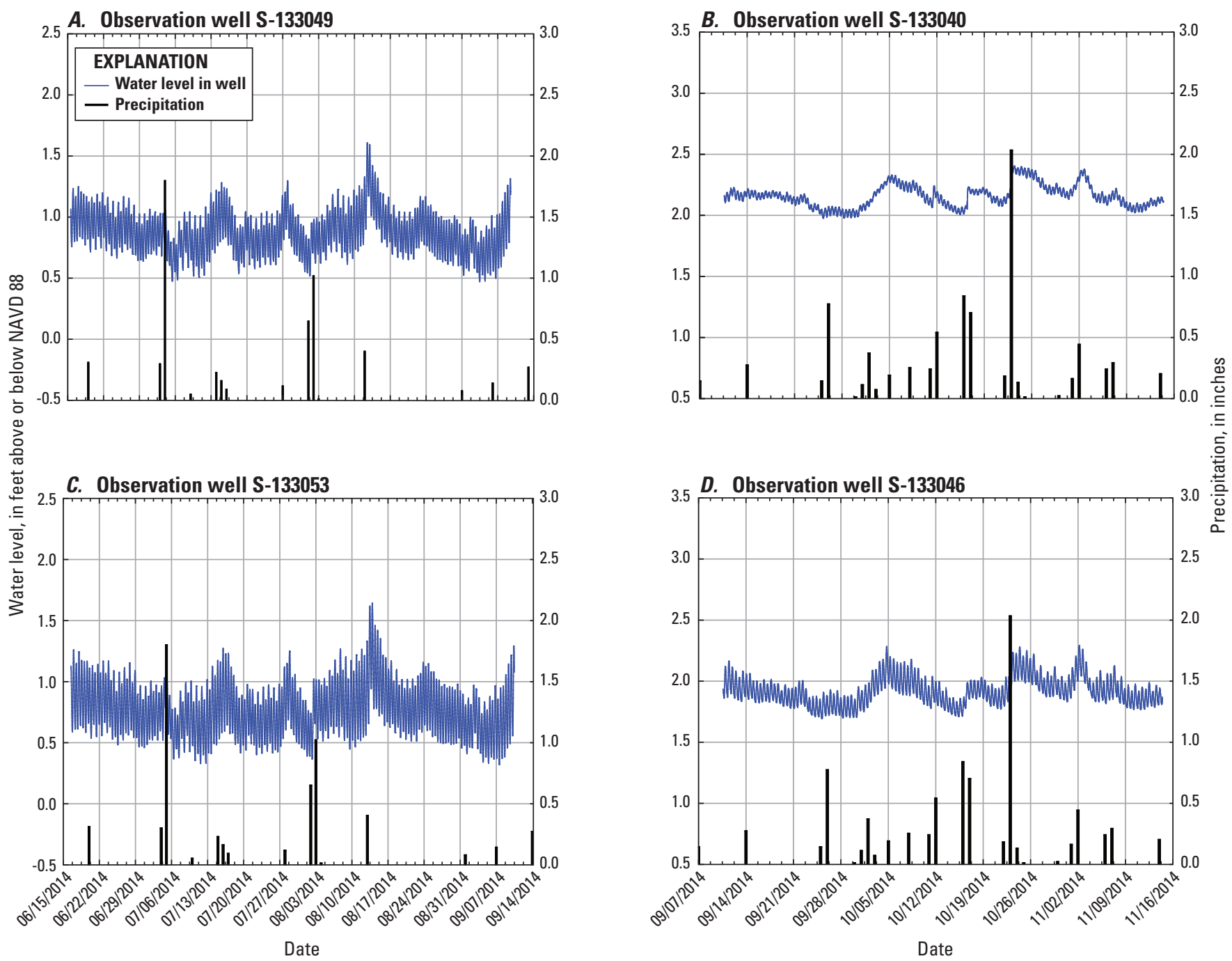

Figure 7. Altitude of water levels in observation wells: $A, \mathrm{~S}-133049 ; B, \mathrm{~S}-133040 ; C, \mathrm{~S}-133053$; and $D, \mathrm{~S}-133046$ in relation to daily precipitation at Bridgehampton, Suffolk County, New York. Locations of the wells are shown on figure 6. Precipitation data are from National Oceanic and Atmospheric Administration (2014). NAVD 88, North American Vertical Datum of 1988.

where

$$
\begin{aligned}
& h \text { is the depth-to-water in the well, in feet, some } \\
& \text { time after pumping begins; and } \\
& h_{0} \text { is the static depth-to-water in the well, in feet, } \\
& \text { before pumping begins. }
\end{aligned}
$$

Hydraulic conductivity is a measure of the capacity of sediments to transmit water. The hydraulic conductivity of the sediments opposite the screens of the water table wells was estimated from specific-capacity test data using the empirical formula presented by McClymonds and Franke (1972), which is based on the Theis non-equilibrium equation (Theis and others, 1954). This formula expresses the average hydraulic conductivity as follows:

$$
K_{a v g} \approx 267.2 \times S C,
$$

where

$$
\begin{aligned}
& K_{\text {avg }} \begin{array}{l}
\text { is the average hydraulic conductivity of the } \\
\text { material opposite the screened interval, } \\
\text { in feet per day; and }
\end{array} \\
& S C \quad \text { is specific capacity of the well per foot of well }
\end{aligned}
$$
screen.

For each specific-capacity test, a submersible pump was used to discharge water from the water table well, and a calibrated bucket and stopwatch were used to measure the discharge rate (Chu, 1996). Water levels in the pumped well were measured with a calibrated electric tape during ambient conditions before pumping started, and during the pumping to document water level drawdown (Stallman, 1971). Water levels in the pumped well also were recorded on a logarithmic schedule using a vented submersible pressure transducer. Each well was 

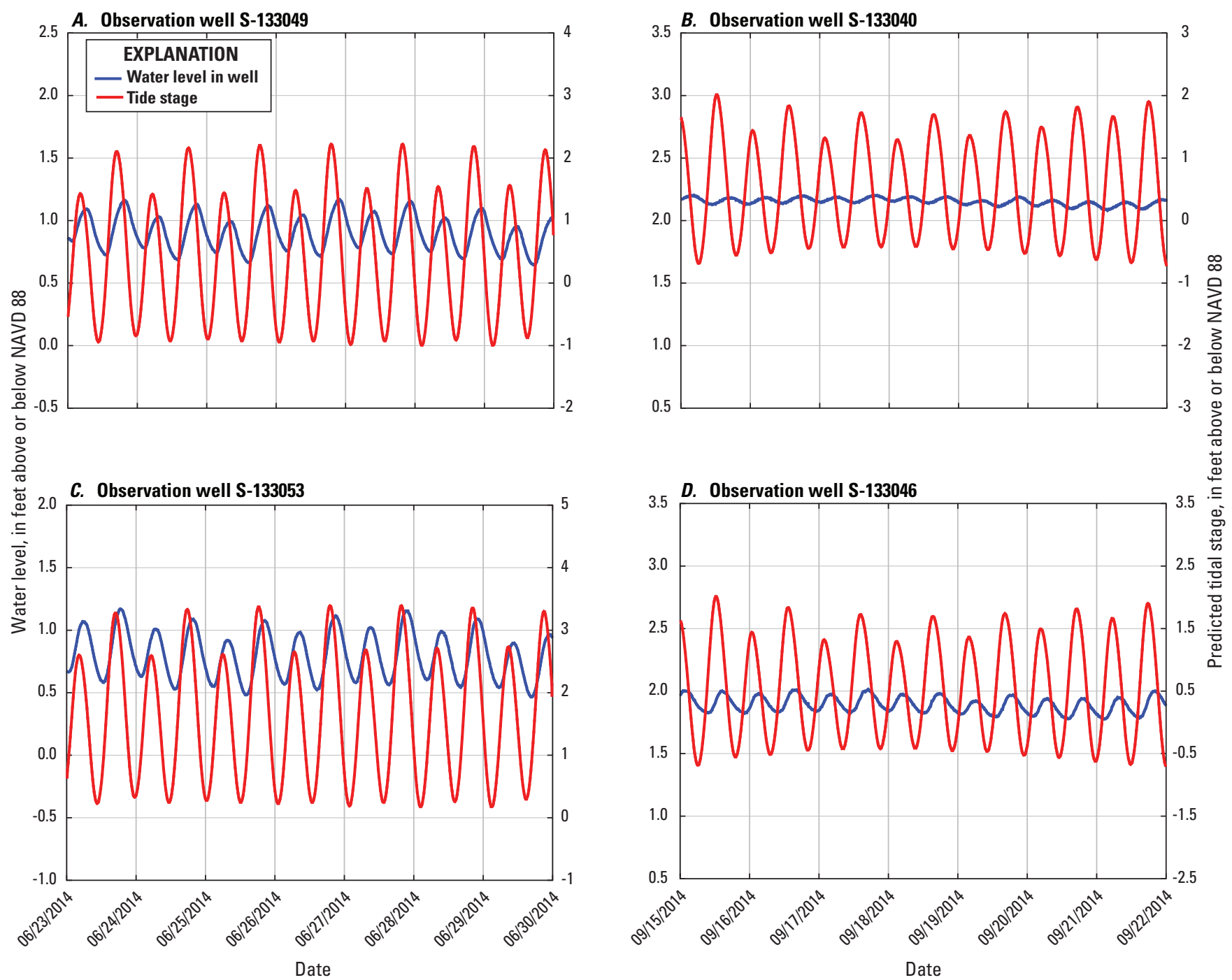

Figure 8. Altitude of water levels in observation wells: $A, S-133049 ; B, \mathrm{~S}-133040 ; C, \mathrm{~S}-133053$; and $D, \mathrm{~S}-133046$ in relation to predicted tide stage at Ponquogue Point, Suffolk County, New York. Locations of the wells are shown on figure 6. Data are from National Oceanic and Atmospheric Administration (2014). NAVD 88, North American Vertical Datum of 1988.

pumped for 90 to 180 minutes at a rate of about 9 gallons per minute $(\mathrm{gal} / \mathrm{min})$.

Equilibrium or steady-state conditions were defined when the rate of water level change was less than or equal to $0.01 \mathrm{ft}$ per 10 minutes (Cunningham and Schalk, 2011). Seven of the nine tested wells reached apparent equilibrium conditions within the first 10 minutes of pumping, and the remaining two wells reached apparent equilibrium conditions within the first 30 minutes (Halford and others, 2006). When possible, wells were pumped during predicted peak high or low tide in Shinnecock Bay, when the rate of sea-level change is minimal, to reduce the potential effects of tides on water levels.

Water level drawdown data for wells S-133046 and S-133053 indicated a tidal influence after water levels reached apparent equilibrium sometime after pumping began. Water level fluctuation because of apparent tidal influence was omitted from the specific capacity per foot of well screen calculation because changes were minimal (less than $0.05 \mathrm{ft}$ ) and do not substantially affect the outcome, and tidal effects seemed to have occurred after apparent equilibrium was reached in the well.

\section{Applied Borehole and Surface Geophysical Methods}

Borehole- and surface-geophysical methods were applied during April 2015 to delineate subsurface lithology and estimate the depth of the freshwater/saltwater interface below the tribal lands. The borehole-geophysical logging methods were gamma, long-normal resistivity, and electromagnetic induction. The surface-geophysical method was time-domain electromagnetic-induction soundings. 
Table 2. Estimated specific capacity and hydraulic conductivity for select wells on or near the Shinnecock Nation tribal lands, Suffolk County, New York.

[NYSDEC, New York State Department of Environmental Conservation]

\begin{tabular}{cccccc}
\hline $\begin{array}{c}\text { NYSDEC site } \\
\text { identification number }\end{array}$ & $\begin{array}{c}\text { Screen length, } \\
\text { in feet }\end{array}$ & $\begin{array}{c}\text { Drawdown, } \\
\text { in feet }\end{array}$ & $\begin{array}{c}\text { Discharge, } \\
\text { in gallons per minute }\end{array}$ & $\begin{array}{c}\text { Specific capacity, } \\
\text { in gallons per minute } \\
\text { per square foot }\end{array}$ & $\begin{array}{c}\text { Estimated hydraulic } \\
\text { conductivity, } \\
\text { in feet per day }\end{array}$ \\
\hline S-133040 & 5 & 2.86 & 9.0 & 0.6 & 170 \\
S-133042 & 5 & 1.48 & 8.6 & 1.2 & 310 \\
S-133043 & 5 & 0.66 & 8.4 & 2.5 & 680 \\
S-133046 & 5 & 1.07 & 9.0 & 1.7 & 450 \\
S-133047 & 5 & 0.78 & 8.6 & 2.2 & 590 \\
S-133048 & 5 & 0.75 & 9.0 & 2.4 & 640 \\
S-133049 & 5 & 0.95 & 9.0 & 1.9 & 510 \\
S-133053 & 5 & 0.89 & 8.8 & 2.0 & 530 \\
S-133054 & 5 & 0.76 & 9.0 & 2.4 & 630 \\
\hline
\end{tabular}

\section{Gamma Logs}

Gamma logs measure gamma radiation emitted by sediments surrounding a well. Gamma radiation is detected by using sodium iodide crystals in conjunction with a photomultiplier tube as a detector (Keys, 1997). Weathering products of feldspars and micas emit gamma radiation from naturally occurring isotopes, such as potassium-40, and tend to be more radioactive than quartz sands. Adsorption and ion exchange in clay create natural concentrations of radioactive daughter products of the uranium and thorium decay series. Gamma logs were collected from wells S-133040, S-133041, S-133045, S-133047, S-133048, S-133052, and S-133053 (fig. 6; table 1; appendix 3) to delineate lithology penetrated by the wells and estimate the depth of the freshwater/ saltwater interface.

\section{Electromagnetic-Induction Logs}

Electromagnetic-induction logs measure the electrical conductivity of sediment and pore water surrounding a well. An alternating current generated by an electrical coil located at the bottom of the probe is transmitted through the formation and is detected by a receiving coil at the top of the probe. The transmitted current induces the flow of eddy currents that creates a secondary magnetic field and a voltage in the receiving coil. The magnitude of the received current is proportional to the electrical conductivity of the measured formation (Keys, 1990). Conductivity is the reciprocal of resistivity and is measured in millisiemens per meter. Induction logging is useful to delineate the freshwater/ saltwater interface in low conductivity formations and can be used in conjunction with gamma logs to distinguish conductive pore water from conductive clays (Stumm, 2001).
An electromagnetic-induction log was collected from well S-132657 on the northern side of Sebonac Road to delineate lithology and estimate the depth of the freshwater/saltwater interface below the tribal lands (fig. 6; table 1).

\section{Long-Normal Resistivity Logs}

Long-normal resistivity logs measure the electrical resistivity of the sediment and pore water surrounding a well (Keys, 1990). Long-normal resistivity logs are less affected by the electrical properties of the borehole fluid than short-normal resistivity logs and, therefore, provide a better representation of formation electrical resistivity. A long-normal resistivity log was collected from well S-133564 near Sunrise Highway north of the tribal lands (fig. 6) to delineate lithology penetrated by the well and estimate the depth of the freshwater/saltwater interface.

\section{Time-Domain Electromagnetic Soundings}

Time-domain electromagnetic soundings measure the electrical resistivity of subsurface sediments and pore water by measuring the intensity of eddy currents that are generated from the decay of (secondary) electromagnetic fields, which are produced by the transmission of alternating current through a square transmitter loop on the land surface (Stewart and Gay, 1986) (North Carolina Division of Water Resources, 2015). The intensity of the eddy currents are measured by a coil receiver inside the square transmitter loop at specific times and depths and logged into a data acquisition box (Geonics Ltd., 2015). Time-domain electromagnetic soundings were collected near wells S-133047 and S-133053 (fig. 6) to estimate the depth of the freshwater/saltwater interface. 


\section{Hydrologic Assessment of the Shallow Groundwater Flow System}

The water table beneath the Shinnecock Nation tribal lands is generally a subdued expression of the land-surface topography and varies from $29 \mathrm{ft}$ bls (below land surface) near Montauk Highway to $0 \mathrm{ft}$ bls near the coast (figs. 9 and 10). The water table is the surface of the upper glacial aquifer and defines the top of the shallow groundwater flow system beneath the Shinnecock Nation tribal lands. The groundwater flow system is recharged by precipitation and upgradient groundwater flow that moves from the recharge zone located generally beneath Sunrise Highway to the marine water bodies that bound the tribal lands to the east, south, and west (fig. 6). The altitude of the water table surface is influenced by daily tidal cycles in the Shinnecock Bay, seasonal variations in precipitation, and substantial local daily precipitation events. Water levels measured in the upper glacial aquifer characterize the configuration of the water table, and indicate distribution and movement of groundwater through the shallow flow system. The sediments in the upper glacial aquifer are of glacial origin and were deposited during the Pleistocene epoch. These sediments lie unconformably on top of the Cretaceous-age sediments that comprise the Magothy aquifer. Parts of the upper glacial and Magothy aquifers contain saltwater at variable depths beneath, and adjacent to, the tribal lands that is indicated by geophysical data. Results of gamma (nuclear) log surveys (fig. 10) along cross section $A-A^{\prime}$ indicate a variable thickness of the upper glacial aquifer and depth to the underlying Magothy aquifer and a finegrained unit at land surface. Specific-capacity tests provided a means to assess the water-transmitting capacity and physical properties of the upper glacial aquifer. For the purpose of this study, the hydrologic assessment is limited to the upper glacial and the shallow Magothy aquifers located beneath, and adjacent to the Shinnecock Nation tribal lands.

\section{Upper Glacial Aquifer}

The glacial origin of sediments composing the upper glacial aquifer distinguished it from the underlying Magothy aquifer and allowed for identification of the geologic contact between these hydrogeologic units. The contact between the upper glacial aquifer and Magothy aquifer was interpreted from historical USGS records (core samples, geologist logs, geophysical logs, and published geologic contacts) and borehole gamma logs (Nemickas and Koszalka, 1982) (Smolensky and others, 1989). Pleistocene-age sediments that comprise the upper glacial aquifer tend to have more reactive (nonconservative) minerals as compared with the Cretaceous-age sediments which comprise the Magothy aquifer. In general, sediments weathered from granitic-type parent rocks deposited more than 34 million years ago will typically be quartz-rich and contain few reactive minerals such as feldspars, biotites, and hornblendes (Goldich, 1938) (Langmuir, 1997).

\section{Contact With Underlying Magothy Aquifer}

The geologic contact of the upper glacial aquifer with the underlying Magothy aquifer was identified in a general northsouth trending section of borehole gamma logs extending from well S-73370, located north of Sunrise Highway and Sebonac Road, to the southernmost extent of the tribal lands, located south of observation well S-133053 (cross section $A-A^{\prime}$, fig. 10). The interpreted contact of the upper glacial aquifer with the Magothy aquifer is present beneath the tribal lands at about 150 to $200 \mathrm{ft}$ bls, and generally decreases in altitude from northwest to southeast.

Depth estimates for the contact of the upper glacial aquifer with the Magothy aquifer are based on the mineralogical content and alteration of the sediments constituting these hydrogeologic units, grain-size sorting (which indicates depositional environment), borehole geophysical logs, and previously published reports (Nemickas and Koszalka, 1982; Smolensky and others, 1989). The glacial drift deposits can range from well to poorly sorted and can contain a variety of silicate minerals weathered (physical, mechanical, chemical) from granitic-type parent bedrock. Generally, sediments that compose the upper glacial aquifer tend to be more chemically reactive than the older sediments in the Magothy aquifer. Upper glacial aquifer sediments tend to be less radioactive, and produce less natural gamma radiation, than sediments in the Magothy aquifer (fig. 10). Borehole gamma logs indicate that sediments in the Magothy aquifer show a much greater range of gamma radiation than sediments in the upper glacial aquifer. This difference is related to the mineralogic composition and sediment sorting of the hydrogeologic units. The Magothy aquifer, in contrast with the upper glacial sediments, tends to be enriched with diagenetic clays (kaolinite clay and other stable clay-bearing minerals) that constitute weathering products from geochemical reactions (dissolution), as dissolved ions in groundwater react with nonconservative minerals (Goldich, 1938; Langmuir, 1997). Clay layers (lenses) deposited as coastal plain sediments (fluviodeltaic) in low-energy environments (Perlmutter and Geraghty, 1963) are also common in the Magothy aquifer. Natural gamma radiation typically increases in the Magothy aquifer, compared with the upper glacial aquifer, because of the increased clay content of the sediments that facilitated identification of the contact between these aquifers (fig. 10).

\section{Surficial-Silty Unit}

A surficial-silty unit was delineated from approximately 0 to $10 \mathrm{ft}$ bls at wells S-133041, S-133045, S-133047, S-133048, S-133052, and S-133053. This unit is in the unsaturated zone below the tribal lands along $A-A^{\prime}$, except south of well S-133052 where it intersects the water table 


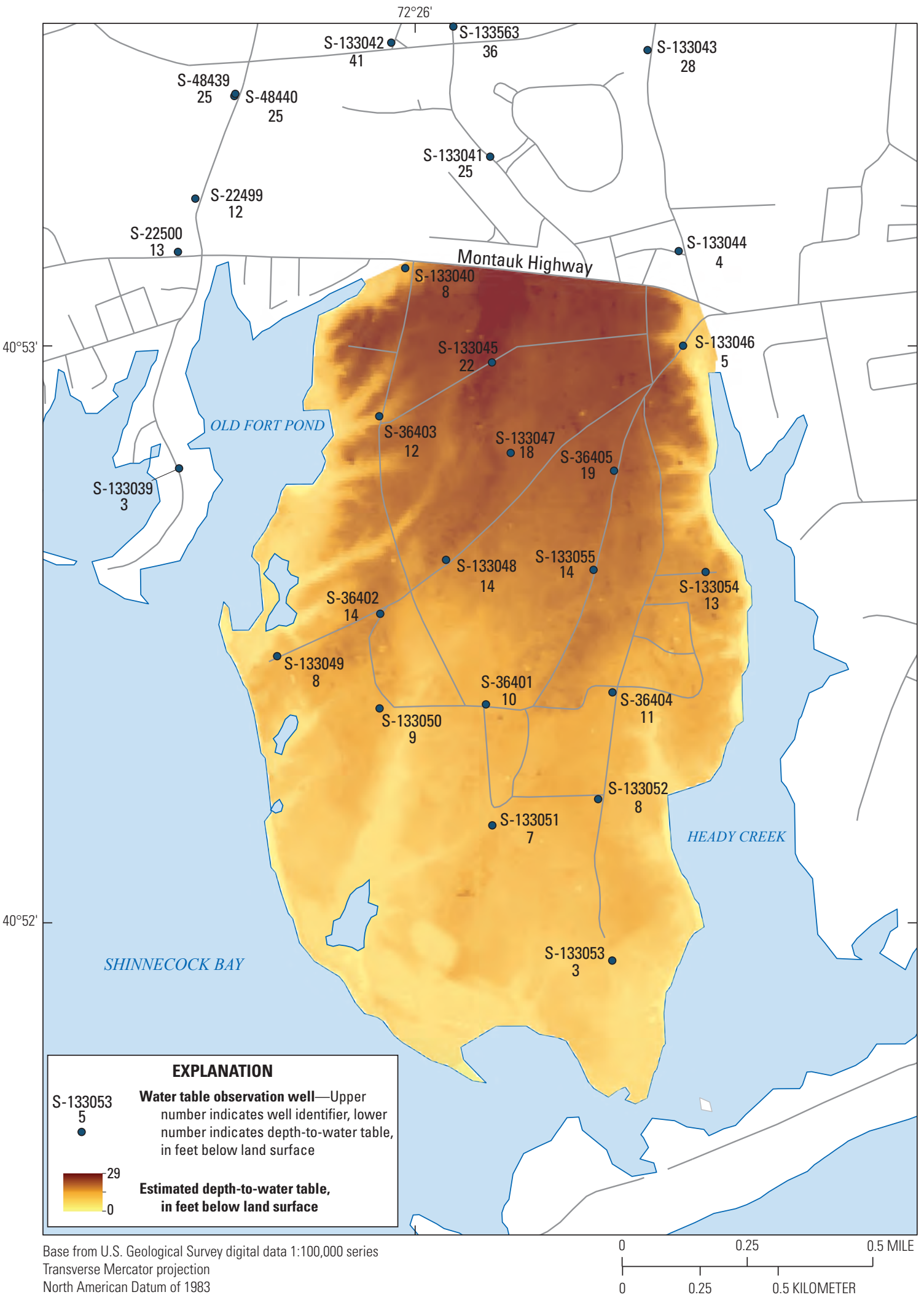

Figure 9. Measured depth-to-water, and estimated continuous depth-to-water surface at Shinnecock Nation tribal lands, Suffolk County, New York, for water levels measured at high tide during May 2014. 


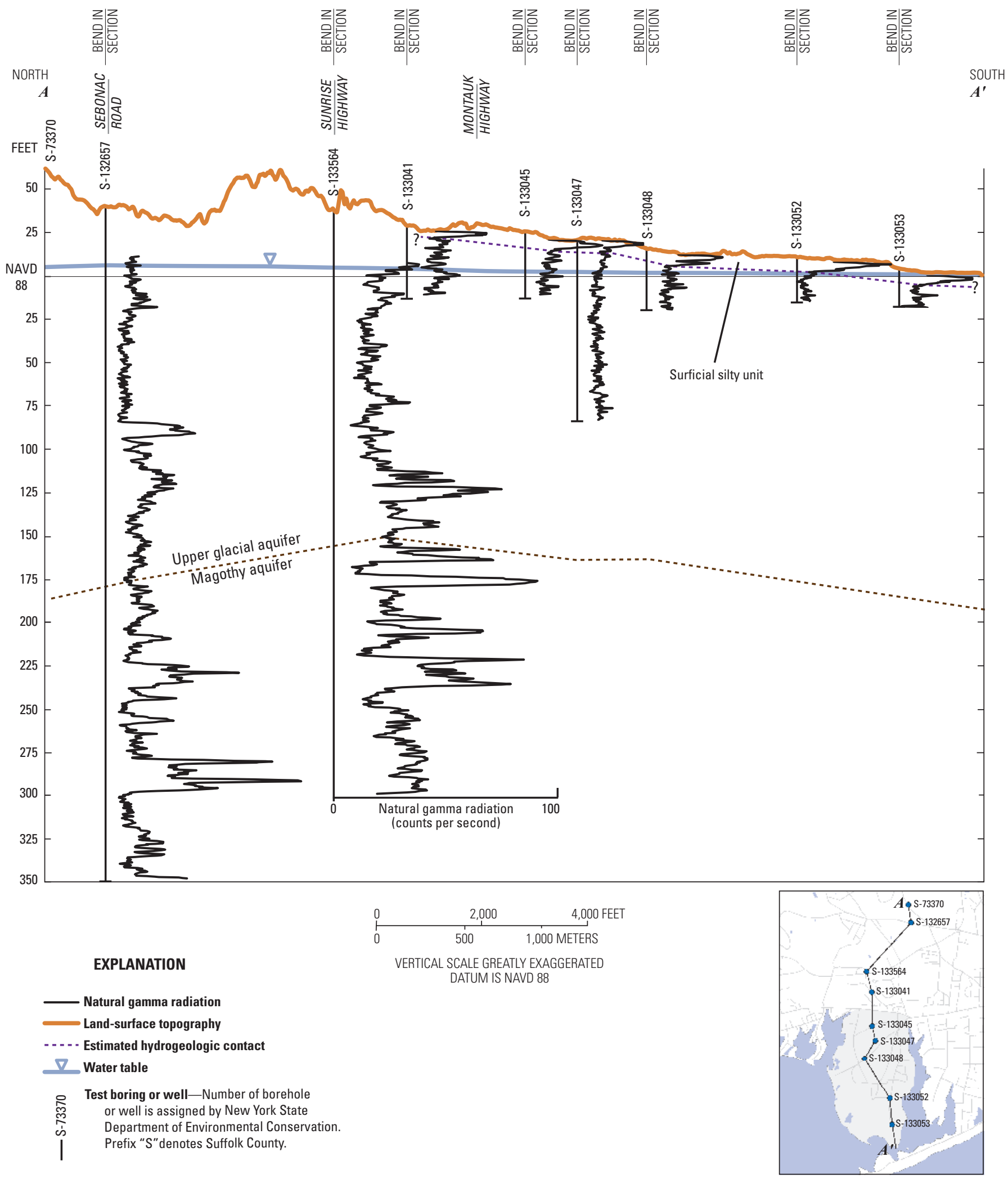

Figure 10. Section $A-A^{\prime}$ showing gamma logs, water table, land-surface topography, and estimated depth of hydrogeologic contacts underlying or adjacent to the Shinnecock Nation tribal lands, Suffolk County, New York. Vertical datum is the North American Vertical Datum of 1988 (NAVD 88). Vertical scale greatly exaggerated. 
because depth-to-water decreases near the coastline (fig. 10). The lithology of this unit was indicated by increased gamma radiation of surficial sediments and verified by analysis of auger-rig drill cuttings from observation well S-133047. The cuttings indicate a silty component from 0 to $5 \mathrm{ft}$ below land surface, but were not analyzed below $5 \mathrm{ft}$ bls because they are considered less representative of formation. The thickness of this unit seems to vary with topography from north to south along the cross section of $A-A^{\prime}$ (fig. 10). Gamma logs indicate the altitude of the silty unit is variable and located subparallel to land-surface topography. The loess-like unit was deposited on top of the glacial outwash plain in a low-energy, possibly eolian (wind-blown) depositional environment. This unit may retard infiltration of storm overwash from coastal storm inundation and could decrease saltwater contamination of the water table aquifer. Additionally, recharge to the water table from precipitation may be reduced in areas where the surficial-silty unit is prominent because of inhibited infiltration and increased overland runoff. Further study is required to characterize this deposit.

\section{Water Table Configuration and Conceptualization of Groundwater Flow}

The water table below tribal lands is the surface of the upper glacial aquifer at which atmospheric pressure is equal to pore-water pressure (Fetter, 2001). The depth to the water table beneath tribal lands generally increases with increasing distance from the coastline, and ranges from $0 \mathrm{ft}$ bls near Shinnecock Bay, to $29 \mathrm{ft}$ bls near Montauk Highway (figs. 9 and 10). Shallow groundwater primarily flows horizontally, lateral and parallel to bedding within the glacial-outwash deposits that comprise upper glacial aquifer. Groundwater flow tends to be many times greater in the horizontal direction (along bedding) as compared with the vertical direction (across bedding). Anisotropy of the upper glacial aquifer on Long Island is about 10:1, in other words, the hydraulic conductivity in the horizontal direction is 10 times greater than in the vertical direction (McClymonds and Franke, 1972). Conceptual descriptions of groundwater flow in this report are limited to horizontal-flow components because (1) a lack of well pairs screened at different altitudes in the upper glacial aquifer prevent analyses of vertical-flow components; and (2) historical anisotropy estimates for the upper glacial aquifer on Long Island (McClymonds and Franke, 1972) indicate that more than 90 percent of groundwater flow is in the horizontal direction.

Water level contour maps indicate that shallow groundwater flows from the recharge zone (highest water levels), generally beneath Sunrise Highway near the higher topography glacial moraine, to the discharge zone generally south of Montauk Highway near the lower topography glacial outwash, and eventually to the marine water bodies that bound the tribal lands (figs. 3 and 11). Shallow groundwater beneath tribal lands generally flows orthogonal to water level contours from the spine (north-south trending line that delineates the centerline of the peninsula) of the peninsula, to the east, south, and west, and discharges into the surrounding embayment and tidal estuaries as upward flow, and to tidal creeks as seepage or base flow (fig. 11). Other sources of discharge include evapotranspiration, and surface runoff (Fetter, 1976). In general, the water table is higher and the slope of the water table (gradient) is steeper during spring as compared with fall because of increased precipitation during the spring months and lower evapotranspiration because of dormant vegetation during late fall, winter, and early spring. The amount of groundwater in the upper glacial aquifer is greater in spring than in fall as mainland springtime water level altitudes exceed $5 \mathrm{ft}$ relative to the North American Vertical Datum of 1988 (NAVD 88) near the recharge zone along the moraine near Sunrise Highway in wells S-132299, S-133043, and S-133563 (figs. 6 and 11). The altitudes of water levels in these wells are less than $5 \mathrm{ft}$ in fall, indicating a decrease in slope of the water table surface in this area.

The location of the 2-ft water level contour (line of equal water level) and the larger spacing between all water level contours during fall (reduced hydraulic-head gradient) compared with water level contours during spring indicates that groundwater in the shallow system is flowing slower in fall than in spring (fig. 11). The 2-ft contour extends south from Montauk Highway about $0.6 \mathrm{mi}$ at its most southern extent in spring 2014; the 2-ft contour extends south of Montauk Highway less than $0.15 \mathrm{mi}$ at its most southern extent in fall 2014.

The slope of the water table tends to increase near tidal creeks where the topographic gradient is larger because of erosion from tidal flux. Lower permeable sediments deposited near tidal creeks also may be responsible for the increased hydraulic gradient in this area. The slope of the water table near tidal creeks along Montauk Highway is less pronounced during fall when compared with spring. The only negative water level recorded during this study is $-0.24 \mathrm{ft}$ at well S-133049 during fall 2014, which could indicate a landward encroachment of saltwater beneath this area of the tribal lands.

\section{Recharge}

Recharge to the water table beneath the tribal lands comes from precipitation and upgradient groundwater flow. Water table contour maps indicate that groundwater generally flows south from the recharge zone (highest water table altitude) beneath Sunrise Highway to the discharge zone (lowest water table altitude) beneath the tribal lands (fig. 11). Continuous water level data from select wells screened in the upper glacial aquifer indicate that water levels increase during and following most precipitation events (fig. 7). Recharge from precipitation was estimated for calendar year 2014 by subtracting evapotranspiration and direct runoff from total precipitation. The estimate does not account for recharge from upgradient groundwater flow, which could be a substantial source of inflow considering the water table beneath the tribal lands is a groundwater discharge zone. Peterson (1986) 


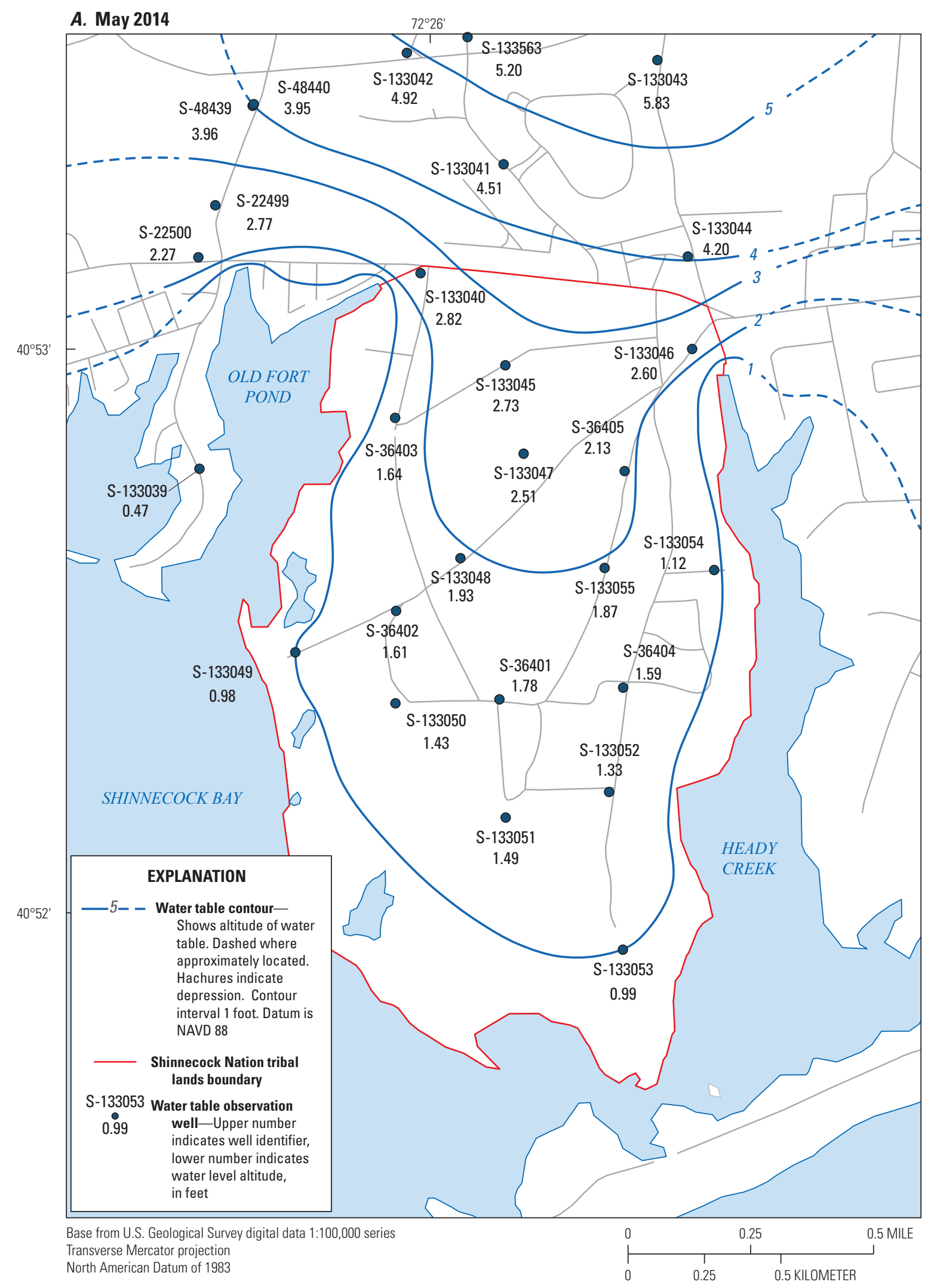

Figure 11. Water table altitude during A, May 2014; and B, November 2014 at the Shinnecock Nation tribal lands, Suffolk County, New York. Water levels were measured during high tide in Shinnecock Bay. NAVD 88, North American Vertical Datum of 1988. 


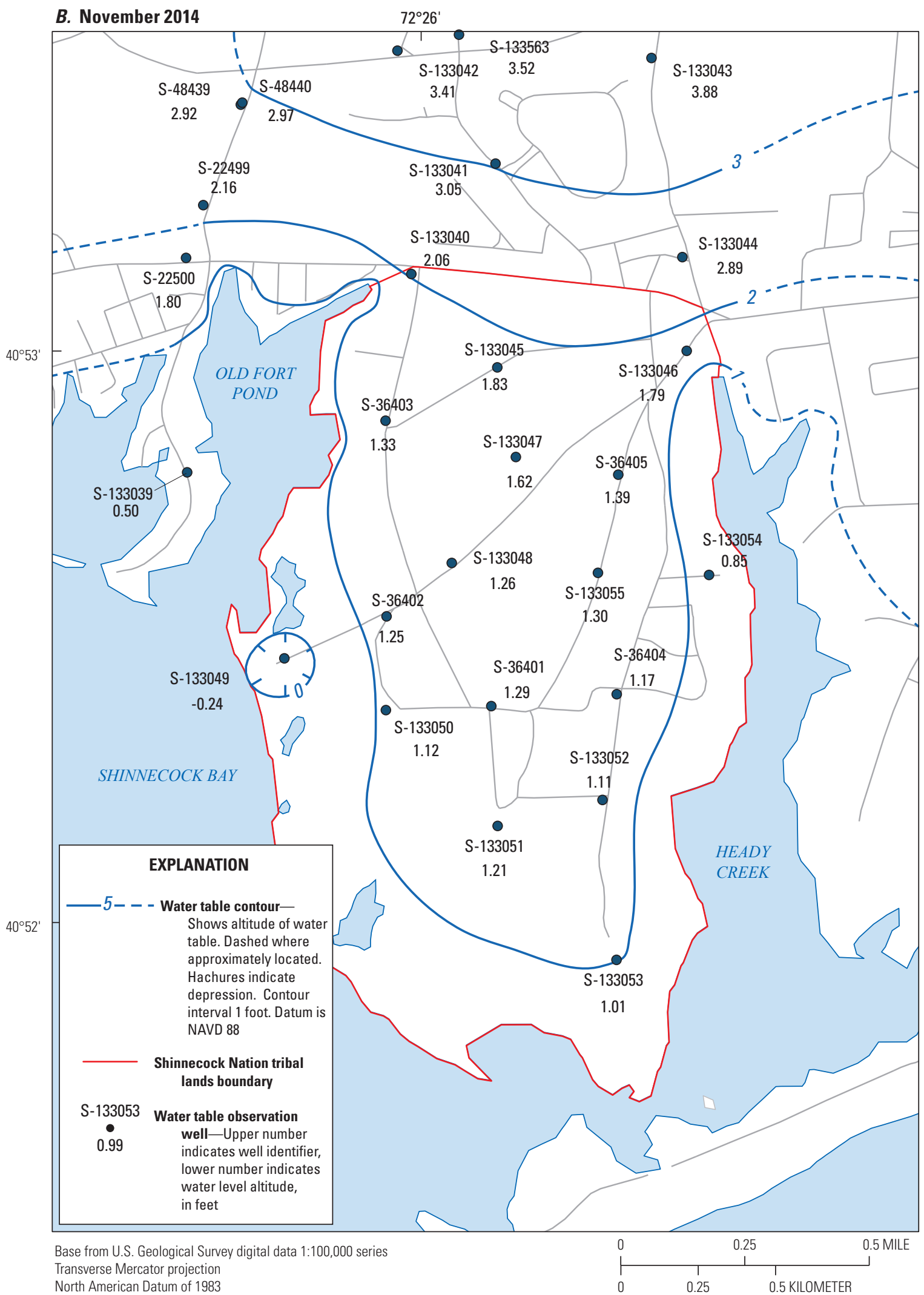

Figure 11.-Continued 
calculated average evapotranspiration values for the Bridgehampton meteorological station from 1968 to 1975 using the Thornthwaite and Mather method (Thornthwaite and Mather, 1957). The estimated evapotranspiration value can be considered a representative average because no extreme annual precipitation events occurred for this time period. Average annual precipitation from 1968 to 1975 is 45.4 in., which is 3 percent lower than the average annual precipitation during the 81-year record. Peterson estimated direct runoff rates in Suffolk County by using topographic maps and stormwater contributing areas to streams and tidewaters created by the SCDHS. Direct runoff is proportional to the degree of urbanization (percentage of total area that is impervious to drainage), so estimated direct runoff rates for 1968-75 could be underestimated for parts of Suffolk County with a high degree of development since 1975. For the purpose of this study, Peterson's estimates for evapotranspiration and direct runoff are considered valid. Using Peterson's estimate, recharge to the water table beneath the tribal lands from precipitation for 2014 is $25.4 \mathrm{in}$.

\section{Effect of Precipitation on Groundwater Levels}

Water levels from water table observation well S-8836, a long-term index well in the USGS-SCDHS cooperative network, were plotted against annual precipitation to show the effects of annual precipitation on historical groundwater levels from 1950 to present (fig. 4). The highest water level altitude ever measured at well S-8836 was recorded during April 2010, which followed a 2-month period (February-March) of more than 20 inches of precipitation, and an unprecedented wet period when 10 of the previous years (2001 to 2010) equaled or exceeded the average annual precipitation (fig. 4). The period from 2001 to 2010 averaged $53.2 \mathrm{in}$. of annual precipitation, which is 13 percent higher than the average total annual precipitation for the 81-year period of record. February (7.01 inches) and March (13.25 inches) 2010 rank as the wettest February and March of record because substantial daily precipitation events occurred on February 24-26 (4.93 in.), March 13th (2.81 in.), and March 29-30 (7.95 in.). Approximately 75 percent of the total precipitation for the two record months (February and March 2010) occurred during 6 days. Extreme daily precipitation events, combined with elevated ambient groundwater levels from above average seasonal recharge, or annual recharge, or both, generally indicate extremely high water level conditions in the shallow groundwater flow system near the tribal lands.

The lowest water level altitude ever measured $(4.01 \mathrm{ft})$ at well S-8836 was in August 1968 following the second driest July (0.61 inch) during the period of record, a 5-month period of below average precipitation (April-August), and an unprecedented dry period when 5 of the 6 previous years precipitation averaged 36.8 in., which is 22 percent below the average total annual precipitation. The summer of 1968 was the 9th driest summer during the period record. Extended periods of above or below average annual precipitation (drought) seem to have an additive (cumulative) effect on water levels in well S-8836 but do not necessarily indicate water level extremes. Large-scale daily precipitation events seem to have a greater effect on discrete water levels in well S-8836 than total annual precipitation. Total annual precipitation seems to indicate long-term water level trends, and correlates with annual changes in storage in the upper glacial aquifer, which is generally represented by water levels in well S-8836.

Monthly water level altitudes from well S-8836 were plotted against total monthly precipitation for a 12 -month period for 2014 to show the effects of seasonal precipitation on water levels (fig. 5). The seasonal response of water levels in well S-8836 to precipitation is generally considered representative of the water table beneath the Shinnecock Nation tribal lands (fig. 5). The water level altitude in well S-8836 for 2014 was highest during April following 2 months of above average monthly precipitation. The second lowest water level $(5.30 \mathrm{ft})$ for 2014 was recorded in October following below average monthly precipitation in June, July, August, and September. The lowest water level measured at well S-8836 (5.25 ft) for 2014 was in November following below average precipitation during 4 of the previous 6 months (June-November), and below average seasonal precipitation for the summer (35-percent below) and fall 2014 (1-percent below). The total growing-season precipitation for 2014 ranked as the 11th driest growing season on record. Discrete water level measurements from well S-8836 generally correlate with above or below average monthly precipitation, or seasonal precipitation, or both. Seasonal water levels in well S-8836 decreased from spring (May) to fall (November) 2014. The lack of long-term water level record wells that are in a similar hydrogeologic setting as the wells in the network, prevented additional analysis of the relationship between annual, seasonal, and daily precipitation and recharge to the shallow groundwater flow system beneath the tribal lands.

\section{Seasonal Water Level Fluctuations and Estimated Change in Groundwater Volume}

Groundwater levels measured during May and November 2014 were used to evaluate seasonal water level changes in wells. A water level-difference contour map shows the distribution of seasonal water level changes observed through water level measurements taken in the well network during spring (May) and fall (November) 2014 (fig. 12). In general, the largest seasonal water level difference is north of Sunrise Highway near the recharge zone (moraine) and the smallest seasonal water level difference is at the extreme southern tip of the tribal lands, where water levels increased from spring to fall. The magnitude of seasonal water level changes generally increased from south to north, except at well S-133049, where water levels decreased by $1.22 \mathrm{ft}$ from spring to fall.

The water level altitude decreased throughout the well network from spring to fall except at wells S-133039 and 


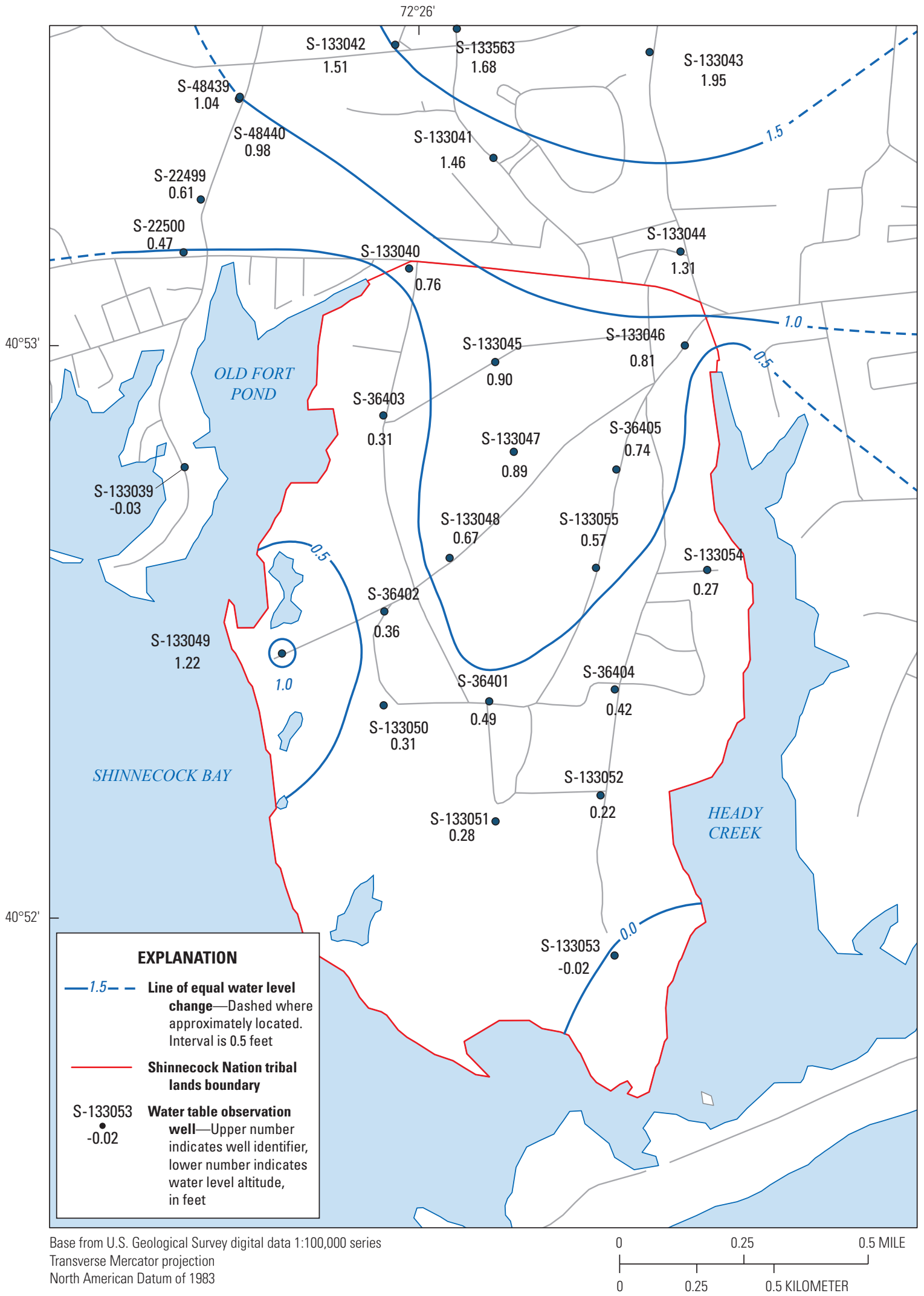

Figure 12. Seasonal difference of water table altitude at Shinnecock Nation tribal lands, Suffolk County, New York, 2014. Differences were calculated by subtracting water levels collected in November 2014 from water levels collected in May 2014. 
S-133053 - water level altitude in these wells increased less than $0.05 \mathrm{ft}$ (fig. 12). Spring water level altitudes ranged from 6.66 to $0.47 \mathrm{ft}$ above sea level (asl) at wells S-132299 and S-133039, respectively, and on the tribal lands ranged from 2.82 to $0.98 \mathrm{ft}$ asl for wells S-133040 and S-133049, respectively (fig. 11). Fall water level altitudes ranged from 5.25 to $-0.24 \mathrm{ft}$ asl at wells S-8836 and S-133049, respectively, and on the tribal lands ranged from 2.06 to $-0.24 \mathrm{ft}$ asl at observation wells S-133040 and S-133049, respectively. The negative water level altitude $(-0.24 \mathrm{ft})$ measured at well S-133049 during November 2014 indicates the potential for landward encroachment of saltwater near the well location.

Seasonal water level differences observed in the 32-well network ranged from 2.18 to $-0.03 \mathrm{ft}$ at wells S-132299 and S-133039, respectively; and from 1.22 to $-0.02 \mathrm{ft}$ at wells S-133049 and S-133053, respectively, located on the tribal lands (fig. 12). The average water level difference is $0.86 \mathrm{ft}$ for the 32-well network, and $0.54 \mathrm{ft}$ for wells located on the tribal lands.

An estimate of the relative change in groundwater volume was made by comparing (subtracting) the modeled surface of the water table for fall from that of spring 2014. Total seasonal groundwater volume loss (change in storage) for the upper glacial aquifer beneath the tribal lands from May 2014 to November 2014 is approximately 20 million gallons, assuming a porosity of 30 percent (Franke and McClymonds, 1972).

\section{Tidal Influence on Water Table}

Groundwater measurements were taken at each well in the 32-well network during May 2014 near low and high tide to evaluate the tidal influence on the water table. In addition, six wells were instrumented with vented submersible pressure transducers that were programmed to measure and record water level and water temperature at 15 -minute intervals. These data were compared with tide stage data recorded at 15-minute intervals at a NOAA tidal station located at Ponquogue Point, New York (station 8512451; fig. 1), to identify potential tidal influence on the water table located beneath the tribal lands (fig. 8; appendix 2).

Water level differences for the 32-well network ranged from 0.30 to $-0.24 \mathrm{ft}$ at wells S-133053 and S-22499, respectively (fig. 13). Water level differences for wells on the tribal lands ranged from 0.30 to $-0.11 \mathrm{ft}$ at wells S- 133053 and S-36403, respectively. Negative values indicate that the measured water level is higher during low tide than at high tide. A water level difference contour map was created to show the distribution of water level change from high tide to low tide during May 2014 (fig. 13). The spatial distribution of water level differences due to tidal fluctuations in Shinnecock Bay indicates that water levels may also be influenced by geology. The line of zero water level change generally trends from the northeastern part of the tribal lands to the southwest. Water levels north of the zero water level change line generally have higher water levels at low tide compared with high tide; water levels to the south of the zero water level difference line generally have higher water levels at high tide compared with low tide. The largest negative water level difference (-0.24 ft) occurred in well S-22499, located just north of Old Fort Pond, and northwest of the tribal lands. The largest positive water level difference $(0.3 \mathrm{ft})$ was in well S-133053, near the southernmost part of the tribal lands. These data indicate that water levels (water table) in wells located north of Old Fort Pond, and beneath the southernmost extent of the tribal lands are most influenced by tidal fluctuation in Shinnecock Bay.

\section{Analysis of Continuous Water Level Data from Selected Wells}

Hydrographs derived from pressure transducer data recorded at six water table observation wells indicate that water levels are affected by upgradient groundwater flow, precipitation, and changes in tidal stage (flux) (figs. 7, 8; appendixes 1 and 2). Detailed analyses of continuous water level data from each well are contained in the following sections. Fifteen-minute interval predicted tide stage data from the NOAA tide station located at Ponquogue Point, and daily precipitation data from NWS meteorological station located in Bridgehampton were used to evaluate hydrologic factors that influence water levels in the instrumented wells (fig. 1).

\section{Well S-133040}

Water levels derived from pressure-transducer data recorded in observation well S-133040 from September 10 to November 14, 2014, range from 2.40 to $1.96 \mathrm{ft}$, average $2.16 \mathrm{ft}$, and have a standard deviation of $0.09 \mathrm{ft}$ (fig. 7). Changes in water level because of precipitation events were examined during tidal cycles to isolate the effects of tidal influence from precipitation-based recharge to wells. A hydrograph showing water levels in well S-133040 and precipitation at Bridgehampton, N.Y., as a function of time indicates that water levels increased by $0.26 \mathrm{ft}$ (peak lowwater level to peak low-water level) during 3 tidal cycles (approximately 72 hours) apparently in response to an approximate 2.34-in. precipitation event that occurred during October 22 to 24 (fig. 7). Water levels increased by $0.17 \mathrm{ft}$ (peak low-water level to peak low-water level) during 2 tidal cycles (approximately 48 hours), apparently in response to an approximate 1.54-in. precipitation event that occurred on October 16 to 17 (fig. 7). There was no apparent water level response to an approximately 0.8 -in. precipitation event on September 26- this may be due to the localized nature of the precipitation event.

A hydrograph showing water levels from well S-133040 and tidal stage at Ponquogue Point was analyzed over a 1-week period from September 15 to 22 to evaluate potential effects of changes in tidal stage (flux) on water levels (fig. 8). 


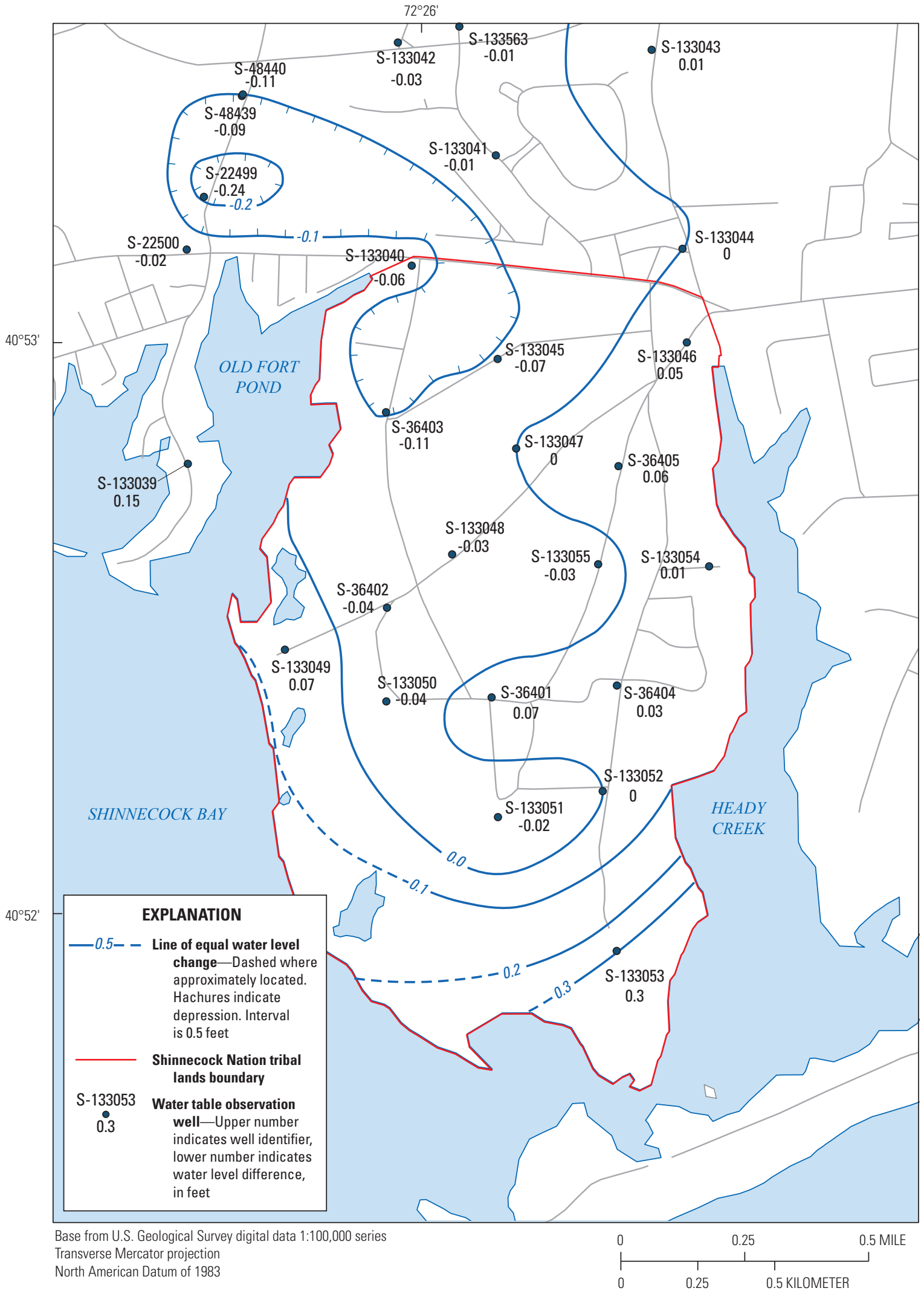

Figure 13. Interpreted water level difference contours, and calculated water level difference values in observation wells at the Shinnecock Nation tribal lands, Suffolk County, New York, 2014. Differences were calculated by subtracting the low-tide water level altitude measurements from high-tide measurements during May 2014. 
The NWS Bridgehampton meteorological station did not record any substantial precipitation events during this week. The average delay time from peak high-tide stage to peak high-water level is 4.2 hours, and the average delay time from peak low-tide stage to peak low-water level is 3.8 hours during the subject period of record. The average magnitude of the tidal influence on groundwater levels is less than $0.05 \mathrm{ft}$, each for high and low tides; the resulting tidal amplitude is less than $0.1 \mathrm{ft}$.

\section{Well S-133046}

Water levels derived from pressure-transducer data recorded in observation well S-133046 from September 10 to November 14, 2014, range from 2.29 to $1.70 \mathrm{ft}$, average $1.92 \mathrm{ft}$, and have a standard deviation of $0.12 \mathrm{ft}$. Water levels increased by $0.24 \mathrm{ft}$ (peak low-water level to peak lowwater level) during 3 tidal cycles (approximately 72 hours) apparently in response to an approximate 2.34-in. precipitation event that occurred during October 22 to 24 . Water levels increased by $0.16 \mathrm{ft}$ during 2 tidal cycles (approximately 48 hours) apparently in response to a 1.54-in. precipitation event during October 16 to 17 (fig. 7). The average delay time from peak high-tide stage to peak high-water level from September 15 to 22 for well S-133046 is 2.25 hours. The average delay time from peak low-tide stage to peak lowwater level is 3 hours. The average magnitude of the tidal influence on groundwater levels is approximately $0.08 \mathrm{ft}$, each for high and low tides; the resulting tidal amplitude is approximately $0.16 \mathrm{ft}$ (fig. 8).

\section{Well S-133047}

Water levels derived from pressure-transducer data recorded in observation well S-133047 from May 16 to June 16, 2014, range from 2.55 to $2.32 \mathrm{ft}$, average $2.44 \mathrm{ft}$, and have a standard deviation of $0.07 \mathrm{ft}$. Water levels apparently do not respond (or the changes are too small to measure) to precipitation events of approximately less than $1 \mathrm{in}$. or to diurnal tidal-stage changes in Shinnecock Bay (appendixes 1 and 2). Water levels in well S-133047 trend downward for the period of record. The primary cause of water level fluctuation in this well is apparently from changes in upgradient groundwater flow (recharge).

\section{Well S-133049}

Water levels derived from pressure-transducer data recorded in observation well S-133049 from June 16 to September 10, 2014, range from 1.61 to $0.47 \mathrm{ft}$, average $0.88 \mathrm{ft}$, and have a standard deviation of $0.18 \mathrm{ft}$. Water levels increased by $0.39 \mathrm{ft}$ during one tidal cycle apparently because of a 0.4 in. precipitation event that occurred on August 13. The hydrograph of well S-133049 indicates water levels increased apparently because of precipitation events that occurred on
July 15 to 17, July 28, and August 2 to 3, 2014. It is unclear if water levels responded to an approximate 2-in. precipitation event that occurred on July 4 to 5 (fig. 7).

A hydrograph was analyzed from June 23 to 30, 2014, to evaluate potential effects of changes in tidal stage (flux) on water levels. The NWS Bridgehampton meteorological station did not record any substantial precipitation events during the week of June 23 to 30 (fig. 7). The average delay time from peak high-tide stage to peak high-water level is 2.75 hours, and the average delay time from peak low-tide stage to peak low-water level is 2.75 hours during the subject period of record. The average magnitude of the tidal influence on groundwater levels is approximately $0.18 \mathrm{ft}$, each for high and low tides; the resulting tidal amplitude is approximately $0.36 \mathrm{ft}$ (fig. 8).

\section{Well S-133053}

Water levels derived from pressure-transducer data recorded in observation well S-133053 from June 16 to September 10, 2014, range from 1.64 to $0.32 \mathrm{ft}$, average $0.77 \mathrm{ft}$, and have a standard deviation of $0.22 \mathrm{ft}$. Water levels increased by $0.16 \mathrm{ft}$ during one tidal cycle apparently in response to an approximate 2.1-in. precipitation event on July 4 to 5 . Water levels increased by $0.38 \mathrm{ft}$ during one tidal cycle apparently due to a 0.4 -in. precipitation event that occurred on August 13. Water levels increased by $0.20 \mathrm{ft}$ during 2 tidal cycles apparently in response to an approximate 1.7-in. precipitation event that occurred on August 2 to 3. The hydrograph of well S-133053 indicates that water levels increased apparently due to precipitation events that occurred on July 15 to 17 , and July 28 (fig. 7).

A hydrograph was analyzed from June 23 to 30, 2014, to evaluate potential effects of changes in tidal stage (flux) on water levels. The average delay time from peak high-tide stage to peak high-water level is 1.75 hours, and the average delay time from peak low-tide stage to peak low-water level is 2 hours during the period of record. The average magnitude of the tidal influence on groundwater levels is approximately $0.24 \mathrm{ft}$, each for high and low tides; the resulting tidal amplitude is approximately $0.48 \mathrm{ft}$ (fig. 8).

\section{Well S-133054}

Water levels derived from pressure-transducer data recorded in observation well S-133054 from May 16 to June 16, 2014, range from 1.40 to $0.94 \mathrm{ft}$, average $1.16 \mathrm{ft}$, and have a standard deviation of $0.10 \mathrm{ft}$. Water levels increased by $0.13 \mathrm{ft}$ during one tidal cycle apparently in response to an approximate 1-in. precipitation event that occurred on May 16. It is unclear if water levels responded to other precipitation events during the period of record. Total daily precipitation events did not exceed 0.7 in. during the period of record except on May 16 (appendix 1). 
A hydrograph was analyzed from May 30 to June 5, 2014 , to evaluate potential effects of changes in tidal stage (flux) on water levels. The average delay time from peak hightide stage to peak high-water level is 3 hours, and the average delay time from peak low-tide stage to peak low-water level is 3 hours during the period of record. The average magnitude of the tidal influence on groundwater levels is approximately $0.08 \mathrm{ft}$, each for high and low tides; the resulting tidal amplitude is approximately $0.16 \mathrm{ft}$ (appendix 1).

\section{Hydraulic Properties}

Estimated hydraulic-conductivity values were derived from the results of specific-capacity tests that were completed at nine observation wells during March 2015. For the purpose of this report, hydraulic-conductivity values are used in conjunction with other hydrologic properties to investigate groundwater travel time along conceptualized flow-path segments of the upper glacial aquifer beneath, and adjacent to the tribal lands. The hydrologic properties of the aquifer have been measured or (where necessary) assumed, and are described in detail throughout the following sections.

\section{Specific Capacity and Hydraulic Conductivity}

Specific-capacity values per foot of well screen for the tested wells averaged 1.9 gallons per minute per square foot ( $\mathrm{gal} / \mathrm{min} / \mathrm{ft}^{2}$ ), and ranged from 0.6 to $2.5 \mathrm{gal} / \mathrm{min} / \mathrm{ft}^{2}$ at wells S-133040 and S-133043, respectively (table 2). Literature indicates that specific capacity per foot of well screen for upper glacial aquifer wells on Long Island range from 0.1 to greater than $4 \mathrm{gal} / \mathrm{min} / \mathrm{ft}^{2}$ (McClymonds and Franke, 1972). Seventyfive percent of the upper glacial wells tested are between 0.5 and $2.5 \mathrm{gal} / \mathrm{min} / \mathrm{ft}^{2}$, and have a median value of 1.3 .

Hydraulic-conductivity values estimated from specific capacity, as described previously, averaged 500 feet per day (ft/d), and ranged from 170 to $680 \mathrm{ft} / \mathrm{d}$ at wells S-133040 and S-133043, respectively (fig. 14; table 2). The hydraulicconductivity estimates are less accurate for wells with screen lengths less than $15 \mathrm{ft}$ because the contribution to discharge from materials above and below the screen zone may increase (McClymonds and Franke, 1972). Although the wells that were pumped for this project have 5 -ft screen lengths, they are screened directly ( 1 to $5 \mathrm{ft}$ ) below the water table. The saturated thickness above the screen zone for the pumped wells is small so the contribution of downward flow to total discharge during pumping is reduced. The potential error in the estimated average hydraulic conductivity may be plus or minus 50 percent of the actual value. The average hydraulic-conductivity estimates are considered reasonable for the purpose of this report despite the potentially large error (McClymonds and Franke, 1972).

\section{Effective Porosity}

Effective porosity represents the percentage of interstitial pore space that is available for fluid flow. It is a function of the diameter of the fluid particle flowing through the void space (Fetter, 2001). A porosity value of 30 percent was used for this report because it is represents the best estimate for sediments in the upper glacial aquifer on Long Island (McClymonds and Franke, 1972; Gureghian and others, 1981; Wexler, 1988).

\section{Average Linear Groundwater Velocity}

Average linear groundwater velocity is the rate at which a particle of water moves from one location to another along a linear flow path through a porous media. The rate can be calculated if the effective porosity, hydraulic conductivity, and the hydraulic-head gradient between two points along the flow path are known. The equation is expressed as follows from Fetter (2001):

$$
v_{x}=-\frac{K}{n_{e}} \times i,
$$

where

$v_{x} \quad$ is the average linear velocity in feet per day;

$K \quad$ is the hydraulic conductivity in feet per day;

$n_{e} \quad$ is the effective porosity (dimensionless); and is the hydraulic-head gradient

(dimensionless).

It is important to note that average linear velocity underestimates the true (or interstitial) velocity of a water particle moving through a porous media. True water particle velocity is greater than average linear velocity because particles of water move along nonlinear flow paths that are highly irregular and dependent on sediment sorting and grain size (Freeze and Cherry, 1979). The true velocity of a water particle moving through a porous media is indeterminate and irrelevant for this study. Average linear velocity can be used to accurately estimate the travel time of groundwater particles through a porous media along linear flow paths if the hydrologic properties of the aquifer can be accurately measured or estimated.

\section{Flow Paths}

A flow path represents a conceptualized line that a groundwater molecule will follow as it moves through an aquifer. Flow-path segments were constructed from the groundwater recharge zone near the moraine (highest water levels), to the discharge zone near Shinnecock Bay (lowest water levels), by orthogonally intersecting water table equipotential lines (water level contours; fig. 14). This method of flow-path construction assumes that the aquifer is homogenous and isotropic along the flow-path segment, and groundwater flow is laminar (Fetter, 2001). A new flow-path segment was 


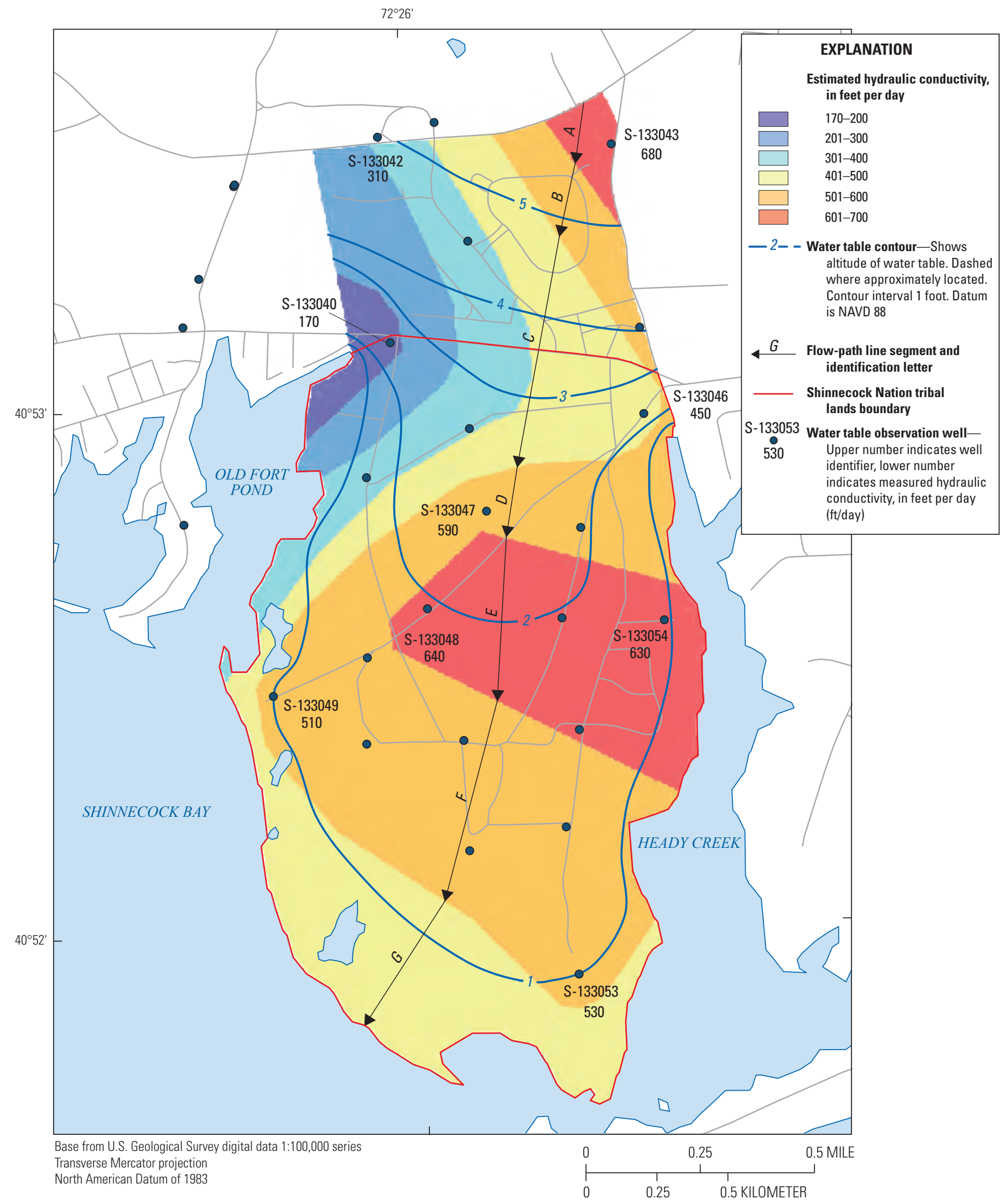

Figure 14. Measured and interpreted hydraulic conductivity, water level altitude contours, and flow-path segments near the Shinnecock Nation tribal lands, Suffolk County, New York, May 2014. 


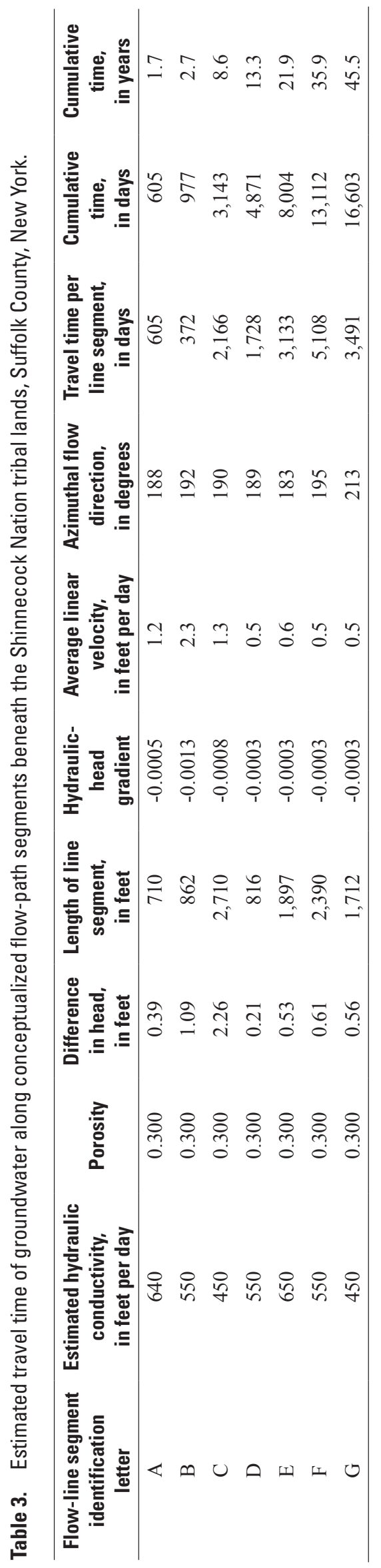


constructed each time the hydrologic properties of the aquifer changed along the flow-path line. Flow-path segments were assigned an estimated hydraulic-conductivity value, an assumed effective porosity, and a calculated hydraulic gradient value (table 3 ). The lengths of the conceptualized flowpath segments were summed to calculate the total horizontal distance a groundwater molecule may travel in the surficial aquifer along segments A, B, C, D, E, F, and G (fig. 14).

\section{Continuous Hydraulic-Gradient Surface}

Horizontal hydraulic-head gradients were calculated for each flow-path segment by dividing the change in hydraulic head (water level difference) along the flow-path segment by the length of the flow-path segment. Natural Neighbor interpolation (Sibson, 1981) was used to create a continuous hydraulic-head surface based on water level measurements from May 2014, as described in the "Water Table Surface and Depth-to-Water Mapping" section. A continuous surface was created to interpolate hydraulic head (water level) where data were missing along flow-path segments. Interpolated hydraulic-head gradients were generated from this continuous surface of hydraulic head and assigned to each flow-path segment (table 3).

\section{Continuous Hydraulic-Conductivity Surface}

A continuous hydraulic-conductivity surface was used to model spatial changes in hydrologic conductivity of the water table aquifer and to construct groundwater flow paths. Hydraulic conductivity was calculated from specific-capacity tests at nine wells located on the tribal lands (table 2). Natural neighbor interpolation (Sibson, 1981) was applied to the calculated hydraulic-conductivity values (fig. 14) to create a continuous hydraulic-conductivity surface, in the same manner as described previously for developing continuous water table and hydraulic-gradient surfaces. Interpolated hydraulicconductivity values were assigned to the constructed groundwater flow paths (table 3 ).

\section{Groundwater Travel Time}

The sum of groundwater travel times along all flowpath segments provided an estimate of the time required for groundwater to flow from the recharge area located to the north of the tribal lands to a discharge zone in Shinnecock Bay (Freethey and others, 1994). Groundwater travel time was estimated along conceptualized flow-path segments by dividing the length of the flow-path segment by the average linear velocity along the flow-path segment (fig. 14; table 3). Travel times for each flow-path segment were summed to compute the total groundwater travel time along the flow path from the recharge area to Shinnecock Bay. Estimated groundwater travel time along flow segments A to G totaled 45.5 years using a porosity value of 30 percent (Franke and
McClymonds, 1972; Gureghian and others, 1981; Wexler, 1988). If a porosity of 25 percent is used, total groundwater travel time along the flow line decreases to 37.9 years; if a porosity of 50 percent is used, total groundwater travel time increases to 75.8 years (fig. 14; table 3 ). Groundwater travel time varies with sediment porosity as derived from Fetter's (2001) equation for calculating average linear velocity.

Interpolated hydraulic-head gradients vary from -0.0013 along flow-path segment $\mathrm{B}$, to -0.0003 along flow-path segments D, E, F, and G. Since the water table is a subdued expression of land-surface topography, changes in topographic gradient typically indicate changes in hydraulic gradient. In general, the topographic gradient is relatively high north of Sunrise Highway along the Ronkonkoma moraine, compared to the shallow dipping outwash plain south of Montauk Highway (figs. 3 and 10). Flow-path segments A, B, and C are located north of Montauk Highway and have the highest hydraulic-head gradients of all segments (fig. 14; table 3). The distance-weighted-mean interpolated hydraulic-head gradient along the 11,000-ft (approximately 2-mi) flow path (A-G) is -0.0005 .

Interpolated hydraulic-conductivity values range from $650 \mathrm{ft} / \mathrm{d}$ along segments $A$ and $\mathrm{E}$, to $450 \mathrm{ft} / \mathrm{d}$ along segments $\mathrm{C}$ and $\mathrm{G}$. In general, hydraulic conductivity is lowest near the northwestern part of the tribal lands near Old Fort Pond and proximal to the Ronkonkoma Moraine (figs. 3 and 14). It increases from northwest near observation well S-133040 (less than $200 \mathrm{ft} / \mathrm{d}$ ), to the south and southeast near well S-133054 (greater than $600 \mathrm{ft} / \mathrm{d}$ ), and with distance from the moraine. Hydraulic conductivity increases from west (less than $300 \mathrm{ft} / \mathrm{d}$ ) to east (greater than $600 \mathrm{ft} / \mathrm{d}$ ), north of the tribal lands, between Sunrise Highway and Montauk Highway. The distance-weighted-mean interpolated hydraulic conductivity along the 2-mi flow path is $530 \mathrm{ft} / \mathrm{d}$.

Estimated average linear velocity ranges from $2.3 \mathrm{ft} / \mathrm{d}$ along flow-path segment $\mathrm{B}$, to $0.5 \mathrm{ft} / \mathrm{d}$ along flow-path segments D, F, and G. Groundwater travels fastest along flow-path segment B, compared with the other flow-path segments, because it has the highest hydraulic-head gradient and second highest hydraulic-conductivity value (fig. 14; table 3 ). The relatively low average linear velocity along flowpath segments $\mathrm{D}, \mathrm{F}$, and $\mathrm{G}$ is caused by the reduced hydraulic gradient south of Montauk Highway. Average linear velocity varies with the inverse of sediment porosity. The distanceweighted-mean average linear velocity along the $2 \mathrm{mi}$ flow path is $0.9 \mathrm{ft} / \mathrm{d}$.

\section{Freshwater/Saltwater Interface}

The depth of the freshwater/saltwater interface along cross section $A-A^{\prime}$ (fig. 15) during April 2015 was estimated using borehole- and surface-geophysical techniques. The thickness of the freshwater zone generally decreased beneath the tribal lands from north to south along cross section $A-A^{\prime}$ as the depth to the interface and the water table altitude decreased 
NOIIJЭS NI QNG9

NOILJᄏS NI ONJg

NOILOتS NI ONJ9

䓌
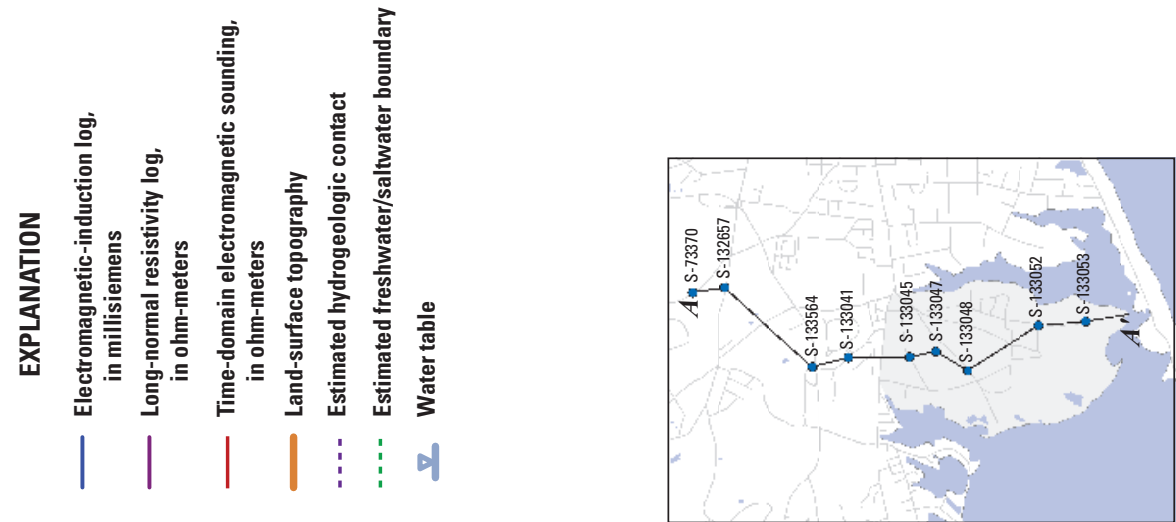

苋

NOILOJS

NI ONJ9

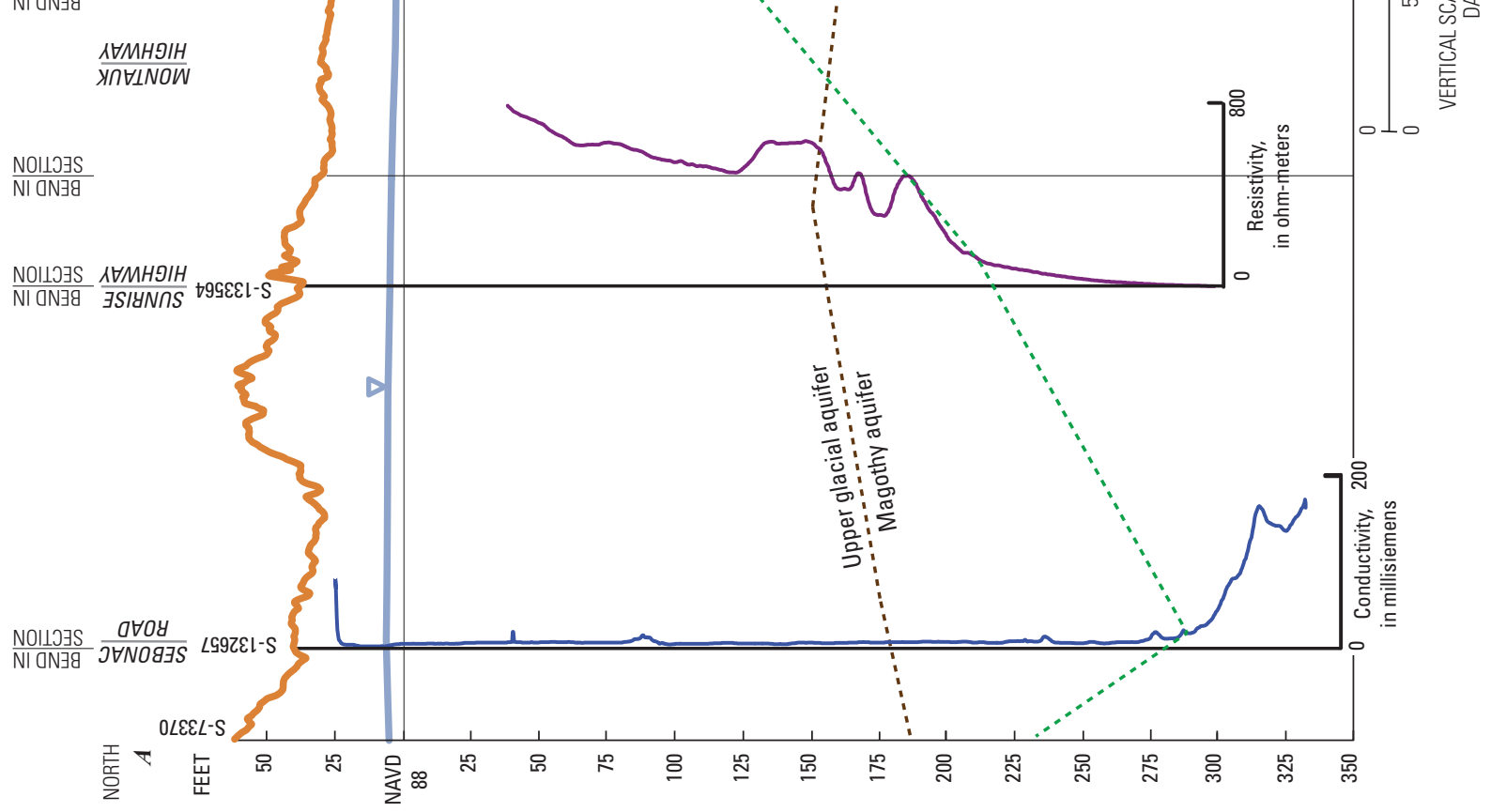


toward Shinnecock Bay. An electromagnetic-induction borehole log collected at observation well S-132657, about 2 mi north of the tribal lands near Sebonac Road, indicated that the interface was at a depth of $325 \mathrm{ft}$ below land surface, or at an altitude of $285 \mathrm{ft}$ (NAVD 88). About $1 \mathrm{mi}$ closer to the tribal lands than well S-132657, an electrical resistivity borehole log obtained from observation well S-133564 located near Sunrise Highway (fig. 15), indicated that the freshwater/ saltwater interface was at a depth of approximately $253 \mathrm{ft}$ below land surface, or at an altitude of $213 \mathrm{ft}$ (NAVD 88). Results of time-domain electromagnetic soundings indicate that the depth of the freshwater/saltwater interface near observation wells S-133047 and S-133053 ranged between 98 and $18 \mathrm{ft}$ below sea level, respectively, with the latter well within $0.3 \mathrm{mi}$ of Shinnecock Bay.

The shape of the delineated interface resembles a wedge with its base (deepest depth to the interface) located below the recharge area (high water levels) of the upper glacial (water table) aquifer north of the tribal lands and an estimated depth of the freshwater/saltwater interface at $0 \mathrm{ft}$ near the coastline at the southernmost extent of the tribal lands (fig. 15). The depth of the freshwater/saltwater interface seems to decrease north of well S-132657 as the altitude of the water table decreases, perhaps because of increasing proximity to Great Peconic Bay (fig. 1). Further study is required to delineate the freshwater/ saltwater interface north of well S-132657.

Sections of the Magothy and upper glacial aquifers contain saltwater at varying depths along cross section $A-A^{\prime}$. Results from the geophysical surveys indicate that the Magothy aquifer beneath the tribal lands contains brackish and salty water and is not considered a source of potable water supply. Low water table altitudes can result in increased saltwater encroachment into the surficial aquifer beneath the tribal lands. This upward movement and shallow depth of the freshwater/saltwater interface can impact water quality in wells that supply water for domestic use.

\section{Ghyben-Herzberg Principle}

The altitude of the saltwater/freshwater interface can be estimated in unconfined aquifers located in coastal areas using the Ghyben-Herzberg (G-H) principle. The G-H principle uses the density ratio of freshwater (1.0 gram per cubic centimeter $\left.\left[\mathrm{g} / \mathrm{cm}^{3}\right]\right)$ to saltwater $\left(1.025 \mathrm{~g} / \mathrm{cm}^{3}\right)$ to estimate the depth of the interface below a datum. The principle states that for every 1 unit of freshwater head above a datum, the depth to the freshwater/saltwater interface is 40 units below the datum.

The G-H principle assumes that the aquifer is under hydrostatic conditions, unconfined, and homogeneous. It underestimates the altitude of the freshwater/saltwater interface in some field settings when the hydrostatic assumptions are not satisfied - this is typical in coastal areas where subsurface freshwater flows to marine water bodies under steady-state (ambient) conditions. Additionally, the boundary separating the freshwater zone from saltwater zone is diffuse due to the geologic characteristics of the porous media and the intermixing of two chemically distinct waters, therefore it is more accurately defined as a transition zone where mixing of freshwater and saltwater occurs (Freeze and Cherry, 1979).

The estimated freshwater/saltwater interface altitude based on the G-H principle and the estimated interface altitude based on the geophysical surveys obtained at observations wells S-132657, S-133564, S-133047, and S-133053 are shown in table 4 . The interface altitude from both estimates decreases from the discharge zone located beneath the southernmost extent of the tribal lands near Shinnecock Bay and observation well S-133053, to the recharge zone located beneath Sunrise Highway near observation well S-133564 and S-132657. In general, depth to the interface increases with increasing geographic distance from the coastline, and increasing water table altitude.

Table 4. Estimated freshwater/saltwater interface altitude at select wells on or near Shinnecock Nation tribal lands, Suffolk County, New York.

[All altitudes are in feet above North American Vertical Datum of 1988 (NAVD 88). NYSDEC, New York State Department of Environmental Conservation; EM, electromagnetic-induction survey; LNR, long-normal resistivity survey; TDEM, time-domain electromagnetic-induction survey]

\begin{tabular}{ccccc}
\hline $\begin{array}{c}\text { NYSDEC } \\
\text { well identifier }\end{array}$ & $\begin{array}{c}\text { Type of } \\
\text { geophysical } \\
\text { survey }\end{array}$ & $\begin{array}{c}\text { Water level during } \\
\text { geophysical survey, } \\
\text { in feet }\end{array}$ & $\begin{array}{c}\text { Estimated altitude of freshwater/ } \\
\text { saltwater interface based on } \\
\text { Ghyben-Herzberg principle, } \\
\text { in feet }\end{array}$ & $\begin{array}{c}\text { Estimated altitude of freshwater/ } \\
\text { saltwater interface altitude from } \\
\text { geophysical survey, } \\
\text { in feet }\end{array}$ \\
\hline S-132657 & EM & 6.7 & -268 & -285 \\
S-133564 & LNR & 5.1 & -204 & -213 \\
${ }^{1}$ S-133047 & TDEM & 2.3 & -92 & -98 \\
${ }^{1}$ S-133053 & TDEM & 0.3 & -12 & -18 \\
\hline
\end{tabular}

'Indicates that TDEM survey was obtained near the well at land surface. 


\section{Conclusions}

The water table below Shinnecock Nation tribal lands is contained mostly in highly permeable Pleistocene glacial drift and outwash sands; near the coastline and tidal creeks, Holocene beach and marsh deposits contain a water table. Results of specific-capacity tests indicate that hydraulic conductivity of the upper glacial aquifer (water table) ranges from 170 to 680 feet per day beneath the tribal lands. The lowest hydraulic conductivity was measured at well S-133040 near the northwestern part of the tribal lands near Old Fort Pond. Hydraulic conductivity increases from the northwest to southeast beneath the tribal lands and generally decreases with decreasing distance to the Ronkonkoma Moraine, that is comprised of poorly sorted glacial drift deposits (figs. 3 and 14). Water levels in water table observation wells were measured at high and low tide during May and November 2014. A water level difference map was created to show the spatial distribution of the apparent effect of tidal stage change in Shinnecock Bay on water levels in wells. Generally, water levels were typically higher at high tide than at low tide, or minimal change was indicated except near the northwestern part of the tribal lands. The map, however, indicates that water levels located near the northwestern part of the tribal lands were higher during low tide than at high tide. Apparent tidal effects on water levels in wells increased from northwest to southeast beneath the tribal lands.

Analyses of hydrographs indicate that the largest tidalinfluence delay time occurred at well S-133040 near the northwestern part of the tribal lands. The hydrograph indicates an apparent 4.2-hour delay time between peak high-tide stage in Shinnecock Bay, and peak high-water level in the well. The small linear distance from the well to the embayment (approximately 500 feet) and the large tidal-influence delay time indicate that the sediment near this part of the tribal lands may not transmit energy from tidal flux (pressure wave) efficiently to the observation well because of low hydraulic conductivity of the aquifer material between the well and Shinnecock Bay. This may be attributed to the proximity of S-133040 to the glacial drift deposits located northwest of the tribal lands, because sediment sorting decreases with distance to the moraine. The measured hydraulic conductivity at well S-133040 (170 feet per day) is characteristic of a silty sand (Freeze and Cherry, 1979), and the negative tidal-influence water level differential (water levels higher at low tide than at high tide) collected during May 2014, support the hypothesis that the aquifer material near this part of the tribal lands is of lower permeability compared with other areas.

Furthermore, a gamma log recorded at well S-133040 shows an increase in gamma radiation near the well screen, which could indicate that the well penetrates fine-grained aquifer material derived from a radioactive (inorganic) parent (source) rock, as gamma radiation typically increases with decreasing grain size (fig. 6 and appendix 3). The spatial extent of the low-permeability silty sand can be estimated, but is unknown at this point. Mapping of this silty-sand hydrogeologic unit would require additional study.

\section{Surficial-Silty Unit}

A surficial-silty hydrogeologic unit located within the upper glacial aquifer was confirmed by gamma logs recorded in wells along cross section $A-A^{\prime}$ that has implications for groundwater flow and the quality of groundwater on the tribal lands (fig. 10). The silt may have been deposited on the shallow-dipping glacial outwash plain as windblown sediment from the Ronkonkoma moraine located north and northwest of the tribal lands. The low permeability of the surficial-silty unit has the potential to impede recharge to the water table from precipitation and to increase runoff. Where the silty unit is prominent and (or) competent, the fine-grained material can restrict downward movement of water and contaminants (Clawges and others, 1999) and can reduce contamination to the water table from infiltration of salty overwash during large coastal storms. The presence of ponded water from poor drainage could create an environment for mosquitos and other pests to thrive. Additional study would be required to map the surficial-silty unit elsewhere on the tribal lands in addition to where this unit has been identified above and below the water table along section $A-A^{\prime}$.

\section{Saltwater in the Upper Glacial and Magothy Aquifers}

The approximate depth of the freshwater/saltwater interface beneath the tribal lands ranges from $190 \mathrm{ft}$ below land surface (-160 feet relative to the North American Vertical Datum of 1988) near Montauk Highway, to 0 feet below land surface (sea level) at the coastline. A cross section of the freshwater/saltwater interface along $A-A^{\prime}$ indicates the altitude of the interface is variable and increases from north to south with decreasing water table altitude. The upper glacial aquifer along $A-A^{\prime}$ contains freshwater from well S-73370 to Montauk Highway. At this point, the freshwater/saltwater interface intersects the hydrogeologic contact between the Magothy and upper glacial aquifers, and the upper glacial aquifer is salty at depth, below the interface. The pore water in the Magothy aquifer beneath the tribal lands is salty and not useful as a source of potable water supply.

Residents with domestic supply wells withdraw potable water from the wedge-shaped (bubble) freshwater zone beneath the tribal lands. Distance from the well screen to the freshwater/saltwater interface can affect the quality and chemistry of the water. The delineation of the freshwater/saltwater interface can be used to inform plans to select the screen zone altitude for new (future) domestic supply wells on the tribal lands. In addition, temporal monitoring of the interface could indicate landward encroachment of salty water because of withdrawals from the shallow aquifer beneath the tribal lands, or from upgradient stresses. 


\section{Groundwater Flow}

Shallow groundwater flows from the inland recharge zone (highest water levels), generally beneath Sunrise Highway, to the discharge zone generally south of Montauk Highway, and eventually to the marine water bodies that bound the tribal lands (figs. 3 and 11). Groundwater flow in the shallow system beneath tribal lands is generally from the spine of the peninsula, to the east, south, and west, and discharges into the surrounding embayment and tidal estuaries as upward flow, and to tidal creeks as seepage or base flow. Paired observation wells screened at offset depth intervals could be used to define upward vertical-flow components in the groundwater flow system because the tribal lands are located on top of a coastal groundwater discharge zone. The freshwaterlsaltwater interface that is located at variable depths beneath the tribal lands can also create an upward flow component because of the increased density of the saline water near the zone of diffusion. Paired observation wells were not included in this study.

Shallow groundwater beneath the tribal lands primarily flows horizontally and parallel to bedding planes within glacial outwash deposits, and tends to be many times greater in the horizontal direction (along bedding planes) than in the vertical direction. Groundwater travel times can be calculated using the techniques and physical principles described in this report but are limited by the assumption that groundwater flow is only in the horizontal direction. Additionally, general or average estimates of the hydraulic properties that were used in time-of-travel calculations can seriously affect the outcome (accuracy) of the computations along the flow-line segments that extend from north of the tribal lands southward to Shinnecock Bay. Accurate and robust time-of-travel estimates can be determined using U.S. Geological Survey and (or) commercially available three-dimensional groundwater modeling software that can simulate the movement of a water particle through a complex, nonhomogeneous groundwater flow system as exists beneath the tribal lands.

Deep test borings with sediment samples would support detailed geophysical data collection to help define the hydrogeologic framework and water quality of the upper glacial aquifer beneath the tribal lands. Additional studies that yield detailed information on the hydrogeology and hydraulic properties of the shallow groundwater flow system are required to support decision making by the tribe's natural resource team as they attempt to solve or mitigate human and ecological health concerns on the Shinnecock Nation tribal land.

\section{Summary}

Understanding the shallow groundwater flow system beneath the Shinnecock Nation tribal lands is critical to identifying potential sources of contamination to the upper glacial aquifer and the marine water bodies that bound the tribal lands to the east, south, and west. Many residents living on the tribal lands depend on the oyster fishery in Shinnecock Bay for their livelihood. Additionally, 6 percent of the households on the tribal lands withdraw water from the upper glacial aquifer as their primary source of potable water supply. In March 2014, the Suffolk County Department of Health Service (SCDHS), in cooperation with the U.S. Geological Survey (USGS), drilled 17 water table wells on and adjacent to the tribal lands. These wells were combined with other existing wells to create a 32-well water table monitoring network that was used to assess local hydrologic conditions.

Seasonal effects on the water table.-Groundwater levels measured during May and November 2014 were used to evaluate seasonal water level changes in wells. Seasonal water level differences observed in the 32-well network ranged from 2.18 to -0.03 feet (ft), and averaged $0.86 \mathrm{ft}$. For the wells located on the tribal lands, seasonal water level difference was less than $1 \mathrm{ft}$ except at well S-133049 (1.22 ft). This anomalous condition may be due to the withdrawal of shallow groundwater for domestic use near the observation well during the summer and fall months. Total seasonal groundwater volume loss (change in storage) for the upper glacial aquifer beneath the tribal lands from May 2014 to November 2014 is approximately 20 million gallons, assuming a porosity of 30 percent.

Tidal effects on the water table.-Water level measurements were made at high and low tide during May 2014 to identify potential effects on the water table caused by changes in tidal stage in Shinnecock Bay. Water level differences for wells on the tribal lands ranged from 0.30 to -0.11 at wells S-133053 and S-36403, respectively. Negative values indicate that groundwater levels are higher at low tide, as compared to high tide, in Shinnecock Bay. The $-0.06 \mathrm{ft}$ tidal water level difference for well S-133040, and the 4.2 hour time lag between peak high-tide stage and peak high-water level quantified from hydrograph data, indicate that water levels in this well are out-of-phase with the tidal cycle in Shinnecock Bay. The $0.30 \mathrm{ft}$ water level difference for well S-133053, and a 1.75 hour time lag between peak high-tide stage and peak high-water level, indicates that this well may be in-phase with the tidal cycle in Shinnecock Bay. In general, tidal effects on water levels increase from the northwest to southeast in the shallow flow system beneath tribal lands.

Recharge from precipitation.-Precipitation data from the Bridgehampton meteorological station was used to identify precipitation influence on the shallow groundwater flow system beneath the tribal lands. Average annual precipitation for the 81-year period of complete record at Bridgehampton is 46.9 inches per year. Total annual precipitation for 2014 is 48.1 inches and estimated recharge to the water table beneath the tribal lands from precipitation for 2014 is 25.4 inches.

Water levels from water table observation well S-8836, were plotted against annual and monthly precipitation to show the effects of precipitation on historical groundwater levels from 1950 to present. Extended periods of above or below average annual precipitation (drought) seem to have an 
additive (cumulative) effect on water levels in well S-8836 but do not necessarily indicate water level extremes. Discrete water level measurements from well S-8836 generally correlate with monthly or seasonal precipitation. Seasonal water levels in well S-8836 decreased from spring to fall 2014.

The highest water level altitude ever measured at well S-8836 was recorded during April 2010, which followed a 2-month period (February-March) of more than 20 inches of precipitation. The lowest water level altitude ever measured at well S-8836 was in August 1968 following the second driest July (0.61 inch) during the period of record, a 5-month period of below average precipitation (April-August), and an unprecedented dry period when 5 of the 6 previous years precipitation averaged 36.8 inches. Extreme daily precipitation events or extended periods of drought may indicate extreme water level conditions in the shallow groundwater system.

Five of the six instrumented wells responded to substantial daily precipitation events during the period of record. Water levels in well S-133040 and S-133046 increased by 0.26 and $0.24 \mathrm{ft}$, respectively, apparently in response to an approximate 2.34-inch precipitation event that occurred during October 22 to 24, 2014. Water levels increased by 0.39 and $0.38 \mathrm{ft}$ in S-133049 and S-133053, respectively, in response to a 0.4 -inch precipitation event that occurred on August 13th. Well S-133047 apparently did not respond to any precipitation events during the period of record.

Hydraulic conductivity.-Specific-capacity tests were completed at nine observation wells during March 2015 to derive estimates for the hydraulic conductivity of the sediments opposite the screen of the water table wells. Hydraulic-conductivity values estimated from specific capacity averaged 500 feet per day (ft/d), and ranged from 170 to $680 \mathrm{ft} / \mathrm{d}$ at wells S-133040 and S-133043, respectively. In general, hydraulic conductivity is lowest near the northwestern part of the tribal lands near Old Fort Pond, and increases from northwest near observation well S-133040 (less than $200 \mathrm{ft} / \mathrm{d}$; appendix 3), to the south and southeast near well S-133054 (greater than $600 \mathrm{ft} / \mathrm{d}$ ), and with increasing distance from the moraine.

Measured hydraulic-conductivity values were used to create a continuous surface hydraulic-conductivity model of the shallow flow system beneath and adjacent to tribal lands for groundwater travel time estimates.

Groundwater travel time.-Groundwater travel time was estimated along conceptualized flow-path segments (A-G) by dividing the length of the flow-path segment by the average linear velocity along the flow-path segment. Estimated average linear velocity ranges from $2.3 \mathrm{ft} / \mathrm{d}$ along flow-path segment $\mathrm{B}$, to $0.5 \mathrm{ft} / \mathrm{d}$ along flow-path segments $\mathrm{D}, \mathrm{F}$, and $\mathrm{G}$. The distance-weighted-mean linear velocity along the $2 \mathrm{mi}$ flow path is $0.9 \mathrm{ft} / \mathrm{d}$. Estimated groundwater travel time along flow segments A to $G$ totaled 45.5 years using a porosity value of 30 percent.

Surficial-silty unit.-A surficial-silty unit was delineated from approximately 0 to $10 \mathrm{ft}$ bls at wells S-133041, S-133045, S-133047, S-133048, S-133052, and
S-133053. Gamma logs indicate the altitude of the silty unit is variable and located subparallel to land-surface topography. The unit was deposited on top of the glacial outwash plain in a low-energy, possibly eolian (wind-blown) depositional environment. A sample from auger-rig spin up verified the lithology of this poorly permeable surficial unit.

Upper glacial/Magothy aquifer geologic contact.-The interpreted contact of the upper glacial aquifer with the underlying Magothy aquifer is present beneath the tribal lands at about 150 to $200 \mathrm{ft}$ bls and generally decreases in altitude from northwest to southeast. The geologic contact was interpreted from the mineralogical content and alteration of the sediments, grain-size sorting, borehole geophysical logs, and previously published reports. Generally, sediments that compose the upper glacial aquifer tend to be more chemically reactive than the older sediments in the Magothy aquifer. Upper glacial aquifer sediments tend to be less radioactive, and produce less natural gamma radiation, than sediments in the Magothy aquifer. Borehole gamma logs indicate that sediments in the Magothy aquifer show a much greater range of gamma radiation than sediments in the upper glacial aquifer.

Freshwater/saltwater interface.-Borehole- and surfacegeophysical methods were applied during April 2015 to estimate the depth of the freshwater/saltwater interface below the tribal lands. The depth to the interface ranges from $325 \mathrm{ft}$ near well S-132657, about 2 mi north of the tribal lands along Sebonac Road, to $18 \mathrm{ft}$ at well S-133053 within $0.3 \mathrm{mi}$ of Shinnecock Bay. The shape of the interface resembles a wedge with its base (deepest depth to the interface) located below the recharge area (high water levels) of the upper glacial (water table) aquifer north of the tribal lands and an estimated depth of the freshwater/saltwater interface at $0 \mathrm{ft}$ near the coastline at the southernmost extent of the tribal lands. In general, depth to the interface increases with increasing geographic distance from the coastline.

Results of the surveys also indicate that the upper glacial aquifer beneath the tribal lands contains brackish and salty water at variable depths that range from approximately $190 \mathrm{ft}$ below land surface near Montauk Highway to 0 feet below land surface (sea level) at the coastline. The Magothy aquifer contains saltwater south of Montauk Highway and is not considered a source of potable water supply for the Shinnecock Nation.

\section{References Cited}

Chu, Anthony, 1996, Results of specific-capacity tests in Kings and Queens Counties, New York, 1919-82: U.S. Geological Survey Open-File Report 96-575, 12 p. [Also available at https://pubs.er.usgs.gov/publication/ofr96575.] 
Clawges, R.M., Stackelberg, P.E., Ayers, M.A., and Vowinkel, E.F., 1999, Nitrate, volatile organic compounds, and pesticides in ground water-A summary of selected studies from New Jersey and Long Island, New York: U.S. Geological Survey Water-Resources Investigations Report 99-4027, 32 p. [Also available at https://pubs.er.usgs.gov/publication/ wri994027.]

Cunningham, W.L., and Schalk, C.W., 2011, Groundwater technical procedures of the U.S. Geological Survey: U.S. Geological Survey Techniques and Methods, book 1, chap. A1, 162 p. [Also available at https://pubs.er.usgs.gov/ publication/tm1A1.]

Fetter, C.W., Jr., 1976, Hydrogeology of the South Fork of Long Island, New York: Geological Society of America Bulletin, v. 87, no. 3, p. 401-406.

Fetter, C.W., Jr., 2001, Applied Hydrogeology (4th ed.): Englewood Cliffs, N.J., Prentice Hall, 586 p.

Franke, O.L., and McClymonds, N.E., 1972, Summary of the hydrologic situation on Long Island, New York, as a guide to water-management alternatives: U.S. Geological Survey Professional Paper 627-F, 58 p. [Also available at https://pubs.er.usgs.gov/publication/pp627F.]

Freethey, G.W., Spangler, L.E., and Monheiser, W.J., 1994, Determination of hydrologic properties needed to calculate average linear velocity and travel time of ground water in the principal aquifer underlying the southeastern part of Salt Lake Valley, Utah: U.S. Geological Survey Water-Resources Investigations Report 92-4085, 30 p. [Also available at https://pubs.er.usgs.gov/publication/wri924085.]

Freeze, R.A., and Cherry, J.A., 1979, Groundwater: Englewood Cliffs, N.J., Prentice Hall, 604 p.

Fuller, M.L., 1914, The geology of Long Island, New York: U.S. Geological Survey Professional Paper 82, 231 p., 2 pls. [Also available at https://pubs.er.usgs.gov/publication/ pp82.]

Geonics Ltd., 2015, Protem receiver: Geonics Ltd. Web site, accessed April 15, 2015, at http://www.geonics.com/html/ protem.html.

Geoprobe Systems, 2014, Geoprobe direct push machines: Geoprobe Systems Web site, accessed December 15, 2014, at http://geoprobe.com/direct-push-technology.

Gobler, C.J., Burson, Amanda, Kock, Florian, Tang, Yingzhong, and Mulholland, M.R., 2012, The role of nitrogenous nutrients in the occurrence of harmful algal blooms caused by Cochlodinium polykrikoides in New York estuaries (USA): Harmful Algae, v. 17, p. 64-74. [Also available at http://dx.doi.org/10.1016/j.hal.2012.03.001.]
Goldich, S.S., 1938, A study in rock-weathering: Journal of Geology, v. 46, no. 1, p. 17-58. [Also available at http://www.jstor.org/stable/30079586.]

Gureghian, A.B., Ward, D.S., and Cleary, R.W., 1981, A finite-element model for the migration of leachate from a sanitary landfill in Long Island, New York; Part IIApplication: Journal of the American Water Resources Association, v. 17, no. 1, 66 p. [Also available at http://dx.doi.org/10.1111/j.1752-1688.1981.tb02590.x.]

Halford, K.J., Weight, W.D., and Schreiber, R.P., 2006, Interpretation of transmissivity estimates from singlewell pumping aquifer tests: Groundwater, v. 44, no. 3, p. 467-471. [Also available at http:/dx.doi.org/10.111 1/j.1745-6584.2005.00151.x.]

In-Situ Inc., 2015, Level Troll 500: In-Situ Inc. Web site, accessed June 16, 2015, at https://in-situ.com/products/ level-temp-data-loggers/level-troll-500-data-logger/.

Kenney, T.A., 2010, Levels at gaging stations: U.S. Geological Survey Techniques and Methods, book 3, chap. A19, 60 p. [Also available at https://pubs.er.usgs.gov/publication/ tm3A19.]

Keys, W.S., 1997, A practical guide to borehole geophysics in environmental investigations: Boca Raton, Fla., Lewis Publishers, $153 \mathrm{p}$.

Keys, W.S., 1990, Borehole geophysics applied to water resources investigations: U.S. Geological Survey Techniques of Water-Resources Investigations, book 2, chap. E2, 150 p. [Also available at https://pubs.er.usgs.gov/ publication/twri02E2.]

Langmuir, Donald, 1997, Aqueous environmental geochemistry: University of California, Prentice Hall, 600 p.

Lonnie, T.P., 1982, Mineralogic and chemical comparison of marine, nonmarine and transitional clay beds on south shore of Long Island, New York: Journal of Sedimentary Petrology, v. 52, no. 2, p. 529-536.

McClymonds, N.E., and Franke, O.L., 1972, Watertransmitting properties of aquifers on Long Island, New York: U.S. Geological Survey Professional Paper 627-E, 24 p., 3 pls. [Also available at https://pubs.er.usgs.gov/ publication/pp627E.]

McCormac, J.C., 1983, Surveying fundamentals: Englewood Cliffs, N.J., Prentice Hall, 522 p.

Monti, Jack, Jr., Como, Michael, and Busciolano, Ronald, 2013, Water table and potentiometric-surface altitudes in the Upper Glacial, Magothy, and Lloyd aquifers beneath Long Island, New York, April-May 2010: U.S. Geological Survey Scientific Investigations Map 3270, 4 sheets, scale 1:125,000, accessed December 1, 2014, at http://dx.doi.org/10.3133/sim3270. 
National Oceanic and Atmospheric Administration, 2015, Monthly and annual precipitation at Bridgehampton, New York: National Oceanic and Atmospheric Administration Web site accessed January 5, 2015, at https://gis.ncdc.noaa.gov/map/viewer/\#app=cdo.

Nemickas, Bronius, and Koszalka, E.J., 1982, Geohydrologic appraisal of water resources of the South Fork, Long Island, New York: U.S. Geological Survey WaterSupply Paper 2073, 55 p., 9 pls. [Also available at https://pubs.er.usgs.gov/publication/wsp2073.]

North Carolina Division of Water Resources, 2015, Time domain electromagnetic geophysics: North Carolina Department of Environmental Quality Web site, accessed April 15, 2015, at http://www.ncwater.org/?page=562.

Perlmutter, N.M., and Geraghty, J.J., 1963, Geology and ground-water conditions in southern Nassau and southeastern Queens Counties, Long Island, New York: U.S. Geological Survey Water-Supply Paper 1613-A, 205 p., 7 pls. [Also available at https://pubs.er.usgs.gov/publication/ wsp1613A.]

Peterson, D.S., 1986, Ground-water-recharge rate in Nassau and Suffolk Counties, New York: U.S. Geological Survey Water-Resources Investigations Report 86-4181, 19 p. [Also available at https://pubs.er.usgs.gov/publication/ wri864181.]

Rydlund, P.H., Jr., and Densmore, B.K., 2012, Methods of practice and guidelines for using survey-grade global navigation satellite systems (GNSS) to establish vertical datum in the United States Geological Survey: U.S. Geological Survey Techniques and Methods, book 11, chap. D1, 102 p. [Also available at https://pubs.er.usgs.gov/ publication/tm11D1.]

Schubert, C.E., deVries, M.P., and Finch, A.J., 2010, Nitrogen loads in groundwater entering back bays and ocean from Fire Island National Seashore, Long Island, New York: U.S. Geological Survey Open-File Report 2010-1081, 16 p. [Also available at https://pubs.er.usgs.gov/publication/ ofr20101081.]

Shinnecock Indian Nation, 2014, History and culture: Shinnecock Indian Nation Web site, accessed November 15, 2014, at http://www.shinnecocknation.org/history.

Shuter, Eugene, and Teasdale, W.E., 1989, Application of drilling, coring, and sampling techniques to test holes and wells: U.S. Geological Survey Techniques of Water-Resources Investigations, book 2, chap. F1, 97 p. [Also available at https://pubs.er.usgs.gov/publication/twri02F1.]

Sibson, R., 1981, A brief description of natural neighbor interpolation, chap. 2 of Vic Barnett, ed., Interpreting multivariate data: New York, John Wiley and Sons, p. 21-36.
Smolensky, D.A., Buxton, H.T., and Shernoff, P.K., 1989, Hydrologic framework of Long Island, New York: U.S. Geological Survey Hydrologic Investigations Atlas HA-709, 3 pls., scale 1:250,000. [Also available at https://pubs.er.usgs.gov/publication/ha709.]

Stallman, R.W., 1971, Aquifer-test design, observation, and data analysis: U.S. Geological Survey Techniques of WaterResource Investigation, book 3, chap. B1, 26 p. [Also available at https://pubs.er.usgs.gov/publication/twri03B1.]

Stewart, Mark, and Gay, M.C., 1986, Evaluation of transient electromagnetic soundings for deep detection of conductive fluids: Ground Water, v. 24, no. 3, p. 351-356. [Also available at http://dx.doi.org/10.1111/j.1745-6584.1986. tb01011.x.]

Stumm, Frederick, 2001, Hydrogeology and extent of saltwater intrusion of the Great Neck peninsula, Great Neck, Long Island, New York: U.S. Geological Survey Water-Resources Investigations Report 99-4280, 41 p. [Also available at https://pubs.er.usgs.gov/publication/wri994280.]

Swarzenski, W.V., 1963, Hydrogeology of northwestern Nassau and northeastern Queens Counties, Long Island, New York: U.S. Geological Survey WaterSupply Paper 1657, 90 p., 13 pls. [Also available at https://pubs.er.usgs.gov/publication/wsp1657.]

Theis, C.V., Brown, R.H., and Meyer, R.R., 1954, Estimating transmissibility from specific capacity: U.S. Geological Survey Open-File Report 54-310, 11 p. [Also available at https://pubs.er.usgs.gov/publication/ofr54310; superseded by U.S. Geological Survey Water Supply Paper 1536-I, https://pubs.er.usgs.gov/publication/wsp1536I.]

Thornthwaite, C.W., and Mather, H.R., 1957, Instructions and tables for computing potential evapotranspiration and the water balance: Centerton, N.J., Drexel Institute of Technology, Laboratory of Climatology Publications in Climatology, v. 10, no. 3, p.185-311.

U.S. Census, 2010 population of persons residing on the Shinnecock Nation tribal lands located in Southampton, New York, accessed March 22, 2016, at http://www.census.gov/.

U.S. Geological Survey, 2012, 10-meter digital elevation model: U.S. Geological Survey The National Map Web site, accessed May 15, 2012, at http://nationalmap.gov/.

Wexler, E.J., 1988, Ground-water flow and solute transport at a municipal landfill site on Long Island, New York: U.S. Geological Survey Water-Resources Investigations Report 86-4070, 52 p., 1 pl. [Also available at https://pubs.er.usgs.gov/publication/wri864070.] 

Appendixes 1-3 


\section{Appendix 1. Water Level Altitude and Precipitation Measured at Selected Wells at the Shinnecock Nation Tribal Lands, Shinnecock, New York}

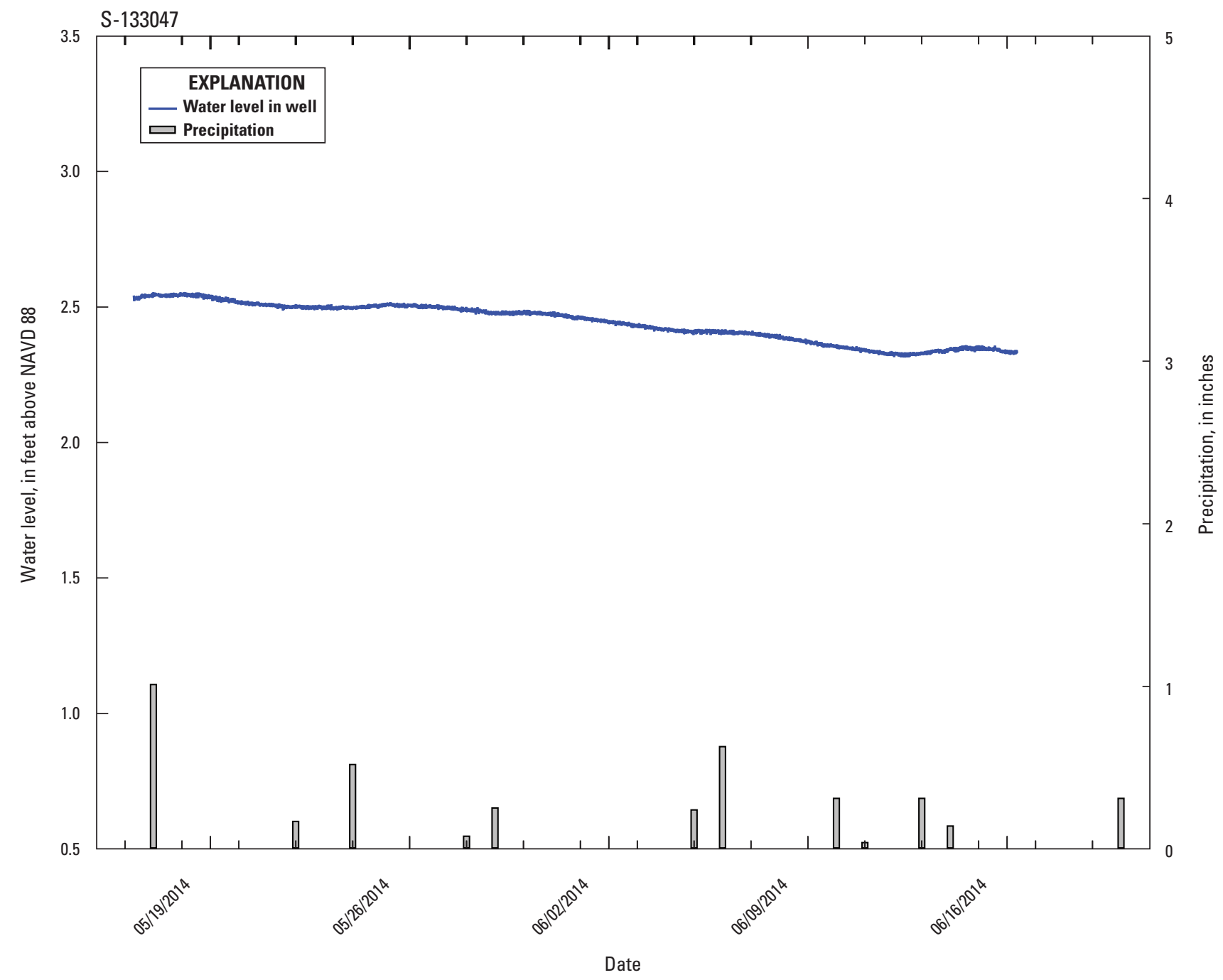

Figure 1-1. Altitude of water levels at well S-133047 on the Shinnecock Nation tribal lands in relation to daily precipitation at Bridgehampton, Suffolk County, New York, in 2014. Precipitation data are from National Oceanic and Atmospheric Administration (2015). The location of the well is shown in figure 6 of this report. NAVD 88, North American Vertical Datum of 1988. 


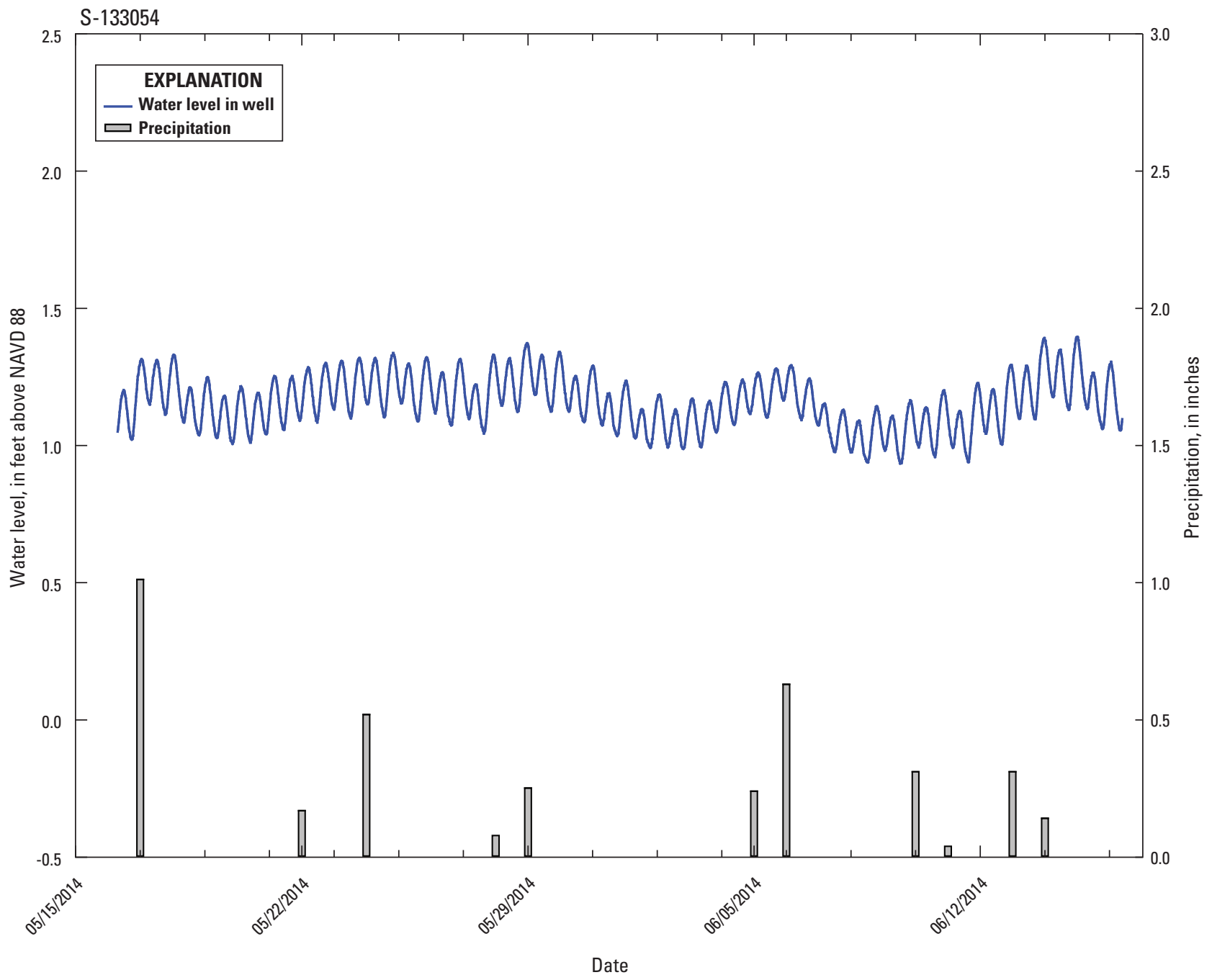

Figure 1-2. Altitude of water levels at well S-133054 on the Shinnecock Nation tribal lands in relation to daily precipitation at Bridgehampton, Suffolk County, New York, in 2014. Precipitation data are from National Oceanic and Atmospheric Administration (2015). The location of the well is shown in figure 6 of this report. NAVD 88, North American Vertical Datum of 1988. 


\section{Appendix 2. Water Level Altitude and Tide Stage at the Shinnecock Nation Tribal Lands, Shinnecock, New York}

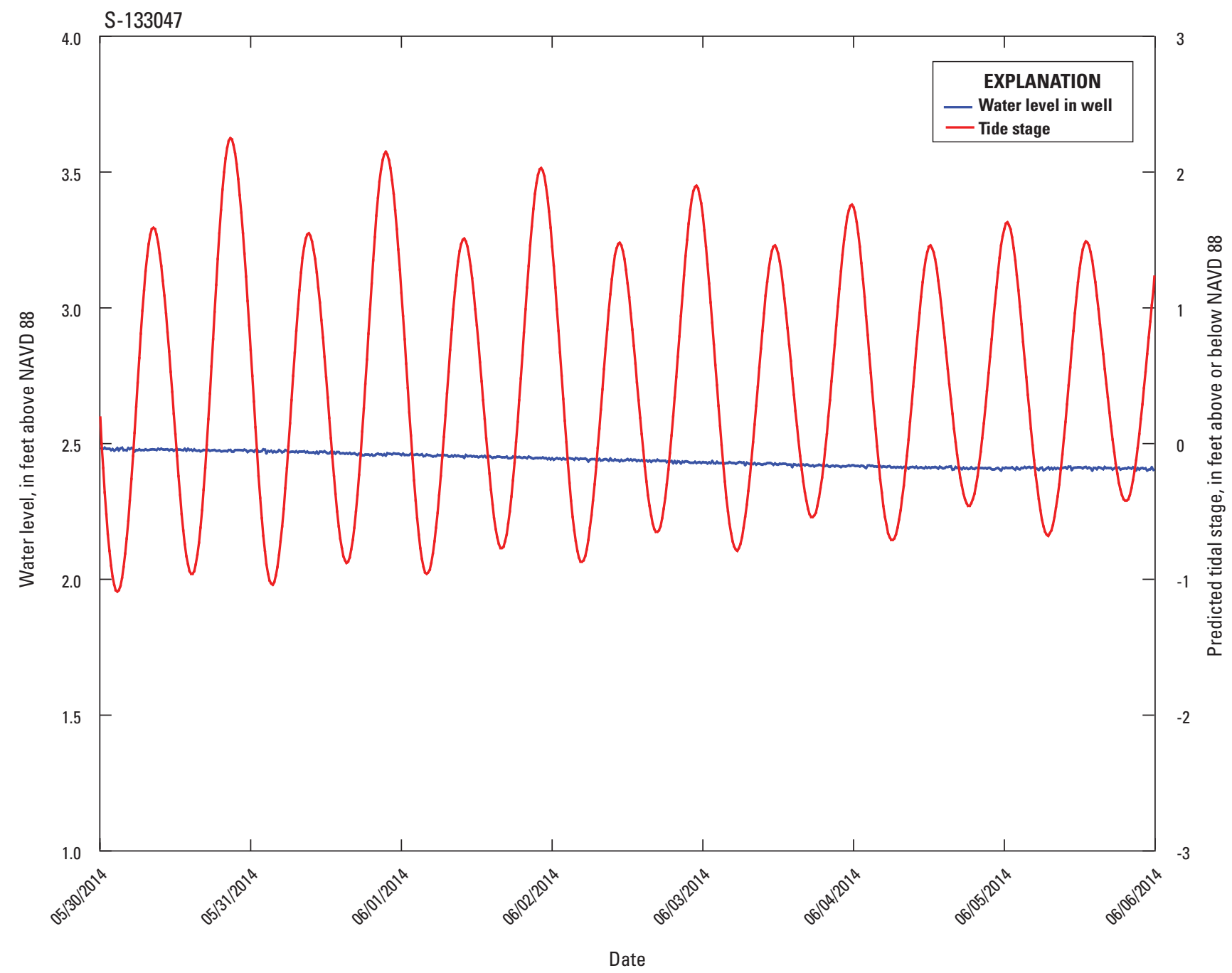

Figure 2-1. Altitude of water levels at well S-133047 on the Shinnecock Nation tribal lands in relation to predicted tide stage at Ponquogue Point, Suffolk County, New York, in 2014. Tide stage data are from National Oceanic and Atmospheric Administration (2015). The location of the well is shown in figure 6 of this report. NAVD 88, North American Vertical Datum of 1988. 


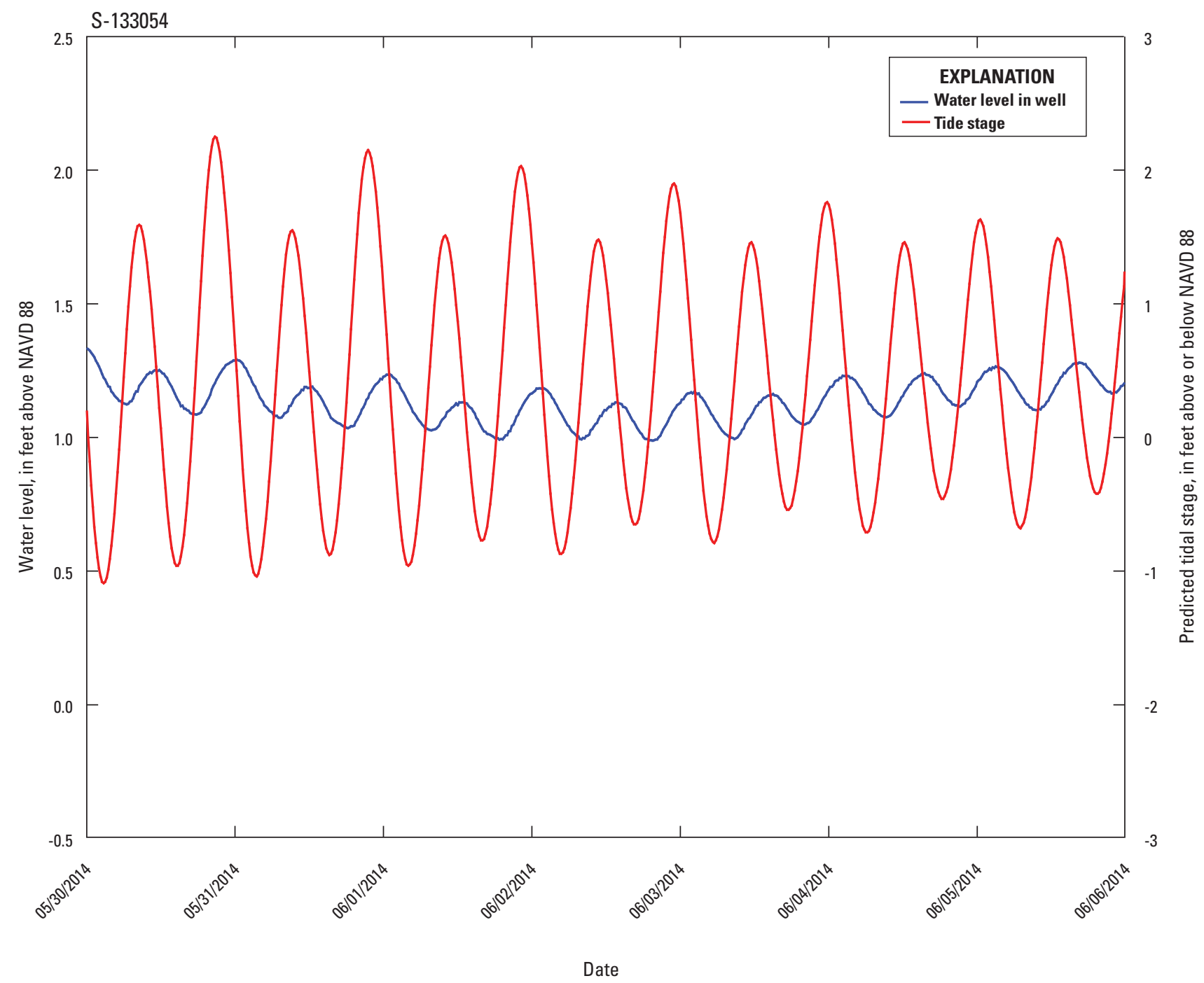

Figure 2-2. Altitude of water levels at well S-133054 on the Shinnecock Nation tribal lands in relation to predicted tide stage at Ponquogue Point, Suffolk County, New York, in 2014. Tide stage data are from National Oceanic and Atmospheric Administration (2015). The location of the well is shown in figure 6. NAVD 88, North American Vertical Datum of 1988. 


\section{Appendix 3. Geophysical Log Collected at the Shinnecock Nation Tribal Lands, Shinnecock, New York}

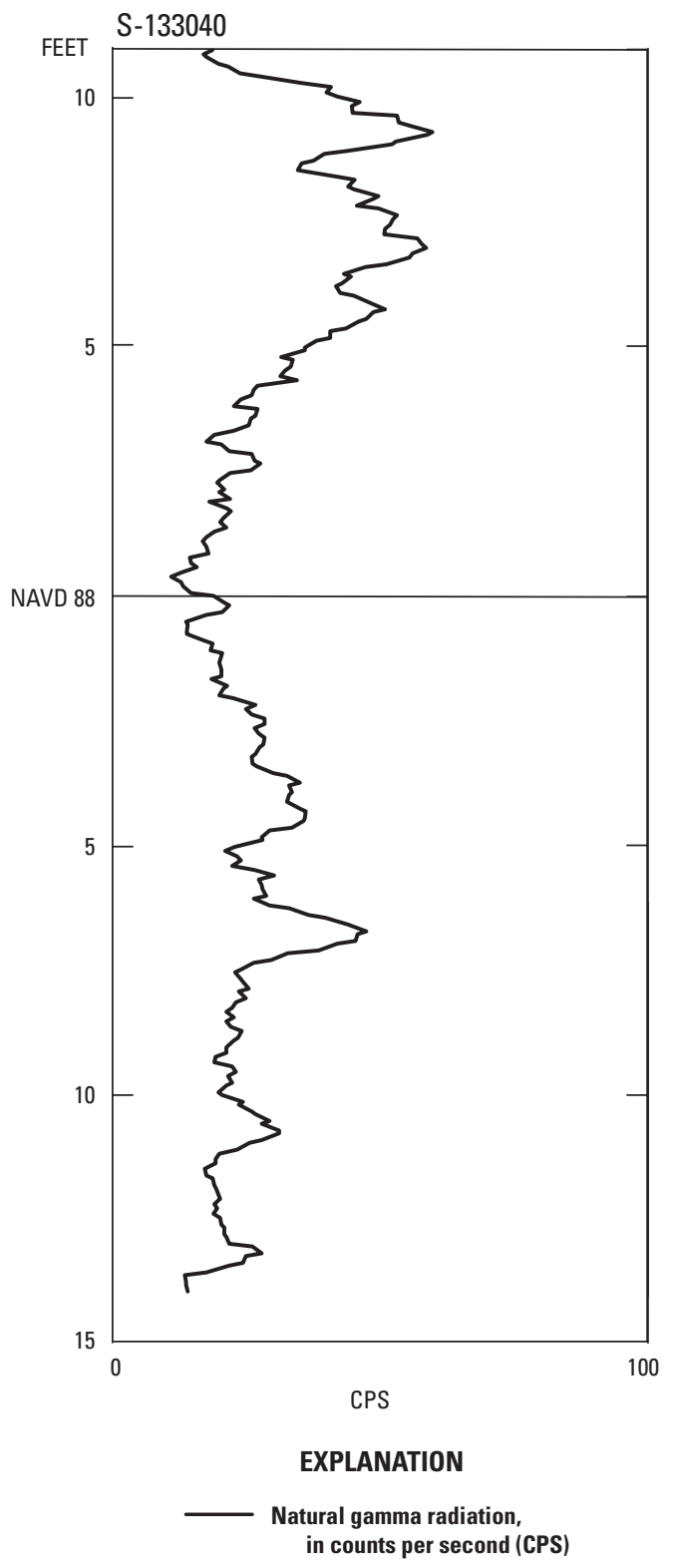

Figure 3-1. Borehole gamma log survey collected at well S-133040 on the Shinnecock Nation tribal lands, Suffolk County, New York, in 2015. The location of the well is shown in figure 6 of this report. Depth is given in feet below top of casing. Gamma values are in counts per second. NAVD 88, North American Vertical Datum of 1988. 
For additional information write to:

Director, New York Water Science Center

U.S. Geological Survey

2045 Route 112, Building 4

Coram, NY 11727

dc_ny@usgs.gov

Information requests:

(518) 285-5602

or visit our Web site at:

http://ny.water.usgs.gov

Publishing support by:

The Pembroke, Rolla, and Reston

Publishing Service Centers 


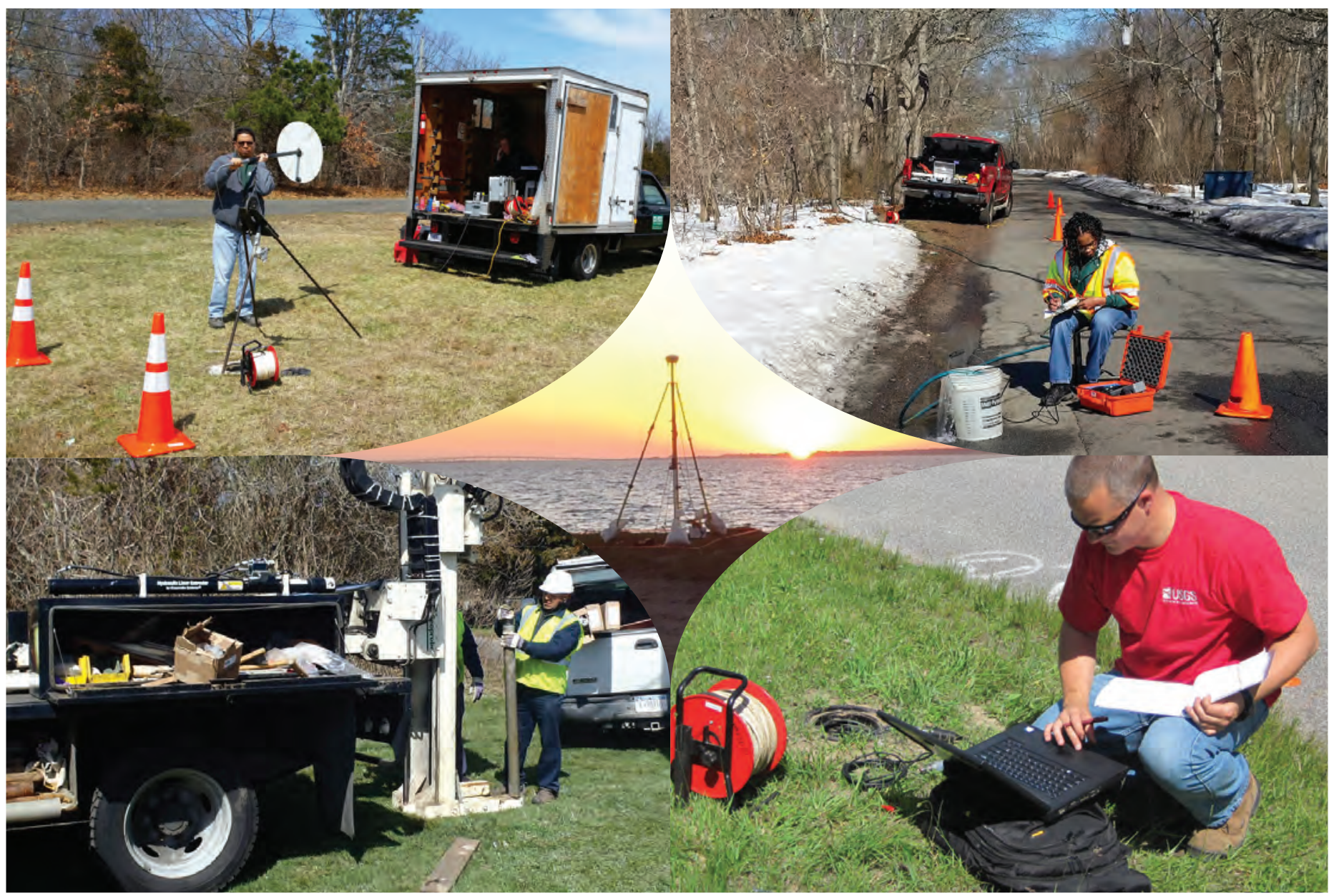

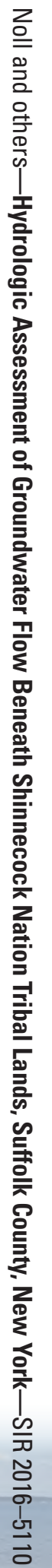
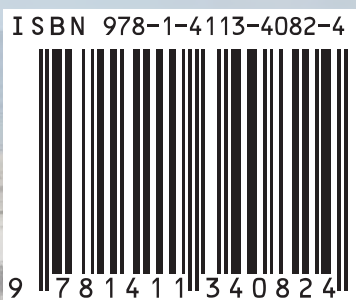